1

2

\title{
Paint It Black: the rise of metallurgy in the Balkans
}

\author{
Miljana Radivojevic ${ }^{1}$ and Thilo Rehren ${ }^{2}$ \\ ${ }^{1}$ Institute of Archaeology, University College London, 31-34 Gordon Square, WC1H 0PY London, UK; \\ email: m.radivojevic@ucl.ac.uk,phone: +44 207679 4936; fax 02076791043 \\ ${ }^{2}$ UCL Qatar, Georgetown Building, PO Box 25256, Education City, Doha, UK; email: \\ th.rehren@ucl.ac.uk
}

\begin{abstract}
This paper integrates archaeological, material, microstructural and compositional data of c. 7000 years old metallurgical production evidence with the aim to address the knowledge of the world's earliest metalworkers. The main focus is placed on copper minerals, ores, slags, slagged sherds and metal droplets coming from four Vinča culture settlements in Serbia and Bosnia and Herzegovina: Belovode, Pločnik, Vinča and Gornja Tuzla, all dated between c. 5400 - 4400 BC. Chemical study of copper minerals throughout all sites points at striking uniformity in selecting black and green minerals from the early days of the settlements' occupation, some of which predate the metal smelting events. Microstructural examination of metal production debris showed convincing technological similarity throughout c. six centuries of copper making in the studied sites, as well as a consistent choice of black and green ores for metal extraction. We argue that black and green ores were intentionally selected as ingredients for the metal smelting 'recipe' in the early stages of Balkan metallurgy based on the knowledge related to their characteristic visual aspects. This finding demonstrates how important the adequate combination of colours was for the early copper metalworkers and suggests a unique technological trajectory for the evolution of metallurgy in this part of the world. It also illustrates the capacity that micro-research carries in addressing the how and why of the emergence of metallurgy, and outlines a methodology for future studies of early metallurgies worldwide.
\end{abstract}

Keywords: Vinča culture; Balkans; metallurgy; copper slag; technology; colour

\section{Introduction}

Studies of prehistoric metallurgy have mostly concentrated on the impact metal artefacts had on consumer societies. Extensive scholarship has been devoted to the role of metallurgy in the rise of social complexity, history of warfare, or building broad chronologies for later prehistory worldwide. However, studying ancient metallurgy goes beyond the typological, stylistic and functional analysis of objects or their distribution, as these represent only some of the building blocks for understanding the knowledge of 
metal production. Such knowledge is inherently related to the perception of immanent properties of both metal artefacts and components required to make them.

The unchanging properties of matter, and the physical laws and principles by which they operate are immanent in the material universe. The recognition of these properties, such as a mineral colour, smell or taste, and the physical laws by which they can be manipulated to a particular purpose are usually constrained by social, technological and environmental circumstances within a given time (Simpson 1963). Cyril Stanley Smith (1981) was among the first to recognise that the origins of technological breakthroughs (such as metallurgy) was motivated more by appreciation for colour, acoustic properties, scent, or reflectance of materials than by the pursuit for better tools or weapons. As he noted, the 'desire to beautify the utilitarian has always stretched the ingenuity of the mechanics' (Smith 1981, p. 330).

The sensory experience of materials has therefore been accordingly acknowledged in the literature and emerged as the key area of interest in the studies of material culture. The term materiality has been most commonly used in scholarship to encompass these immediately perceptive aspects of an object together with the social connotation of its use (cf. Jones 2004, p. 330). Perhaps the most popular definition of materiality is put forward by Boivin (2008, p. 26), who considers materiality as the physicality of the material world, since it has dimensions, it resists and constraints, and it offers possibilities for the (human) organism as outlined by a set of physical properties. Nevertheless, the use of this term has been burdened with its own intellectual luggage, carried over from the times when it served to show that material culture has had a profound impact on the social world (Gosden 2005, p. 185). Furthermore, for scholars coming from the worlds of both archaeology and materials science, like us, the term materiality, as defined by its use, lacks the depth for the resolution of evidence we are looking at.

While we acknowledge that physical properties of a finished object, together with its dimensions of use, and material advantages and limitations constitute an object's materiality, we also believe that the route to its final shape, or the production process, provides crucial complementary information to this concept. It is the properties of raw materials, their acquisition and preparation, as well as manufacturing techniques that hold information inherent to the appearance and value of the produced object (cf. Smith 1981). We hold that the study of immanent properties of all material components involved in the object making within a given context can contribute to an insightful account of the knowledge applied in its production, and is as important as the final form an object takes. We thus argue that the concept of materiality is short of this 'organic' dimension, which makes it unsuitable for the scope of our study presented here. What we aim to demonstrate is that only an understanding of immanent properties of all production components interacting within specific historical circumstances can shed light on the how and why of an object's making in an archaeological inquiry.

Archaeometric studies have long identified the importance of understanding the interaction of physical properties of materials and social practices involved in their manufacture (e.g. Sillar and Tite 2000; Tite et al. 2001; Jones 2004; Martinón-Torres et al. 2007; Martinón-Torres and Rehren 2009; Killick and Fenn 2012). Sillar and Tite (2000) address this interaction with the idea of 'embedded technologies', which stands for the wider contextualisation of techniques within cultural and environmental surroundings. A good ethnographic example is provided in the study of Shona iron smelting furnaces, which demonstrated that the surface appearance of their furnaces is not as powerful as the material transformations taking place inside them (Schmidt 2009, p. 279). A powerful set of recorded rituals surrounding the smelting 
activity unveiled the supremacy of the interior material transformation, and pointed at the analytical potency of all evidence coming out of an activity such as metal making.

Many ethnographers made the connection between distinctive colours, brilliant surfaces and ritual power and potency (Chapman 2007a). Art, technology and aesthetics have already been addressed within a technical system called 'the technology of enchantment' (Gell 1992). Enchantment is acknowledged as associated with technology, as its various dimensions have the power to 'enchant' during ceremonial or commercial gift exchange, or rituals. The power of artistic objects is particularly distinctive when it comes to their outer appearance, such as colour, or shine. An excellent example of integration of aesthetics and archaeometric techniques is provided by Hosler (1994), who explored the significance of aesthetics and sound in metal use in historic west Mexico and discussed how those shaped the Mesoamerican worldview.

Post-medieval crucible production is another example that pointed out the importance of sensory aspects during the production steps, when choosing a suitable type of clay for crucible making (Martinón-Torres and Rehren 2009). Archaeometric analysis revealed that the reputable endurance of Hessian and Bavarian crucibles was due to particular properties of naturally occurring clays as well as their manipulation during the firing process. Martinón-Torres and Rehren (2009, p. 69) argue that the potters must have been aware of the qualities of this particular clay, such as its colour, texture, plasticity, taste or smell, and opted for the right combination of these aspects when choosing the raw material for their crucibles. It was therefore the complete sensorial aspect of the raw material, in addition to its colour, that shaped potter's preference for a particular type of clay.

Both studies, and the latter in particular, indicated novel research avenues for the application of material science in addressing the reasoning behind an object making. Significantly, what emerged to be an important part for understanding the process of object making, besides manufacturing steps, colour and mechanical properties of the produced artefacts is the physics of the production process and the constraints imposed by it (cf. Vincenti 2000; Roux 2010; Charlton et al. 2010). Coming back to the importance of understanding immanent properties of materials, we need to acknowledge the historical manifestations of particular combinations of these immanent processes, or configurations. The crucial distinction here is between timeless (immanent) and particular (configurational) properties of an observed phenomenon, which always act together (Simpson 1963; Wolverton and Lyman 2000). This is where we believe the key lies to assessing the knowledge of particular processes, such as early copper smelting. By identifying immanent properties of materials and processes involved in early copper smelting and their particular combination at a given time in (pre)history, we can gain the information on this specific (configurational) development at the time.

The when and where of (extractive) metallurgy has been attracting scholarly attention for decades. The discovery of the c. 7000 years old copper smelting debris in the Vinča culture settlement of Belovode in eastern Serbia showed that one of the origins of metallurgy can be sought in the heart of the Balkans, besides the traditionally proposed locations in the Near East, where copper smelting activities are argued as roughly contemporaneous, following on from a long practice of malachite bead making (for discussion see Roberts et al. 2009; Thornton 2009; Radivojević et al. 2010). Thus, this discovery revived the theory of multiple origins of metallurgy, indicating that it was invented in at least three places in the world: the 

Ruíz 2012; Roberts and Thornton 2014).

While the main focus in the ongoing debates of single vs. multiple inventions of metallurgy still rests on finding 'the earliest' evidence for metal production, it overlooks the immense capacity of technological studies to reveal how independent the knowledge of metallurgy was. The case study on the early development of Eurasian metallurgy presented here will therefore address both immanent and configurational aspects of the world's earliest known metal production and attempts to provide a more comprehensive assessment of the $5^{\text {th }}$ millennium BC metal production technology in the Vinča culture, taking into account four settlements: Belovode, Vinča-Belo Brdo, Pločnik and Gornja Tuzla (Fig 1). In this study, the emphasis is set on extractive technology only, as it is a crucial aspect for discussing the evolution of metal production technology and its independence from potentially contemporary developments elsewhere. Microstructural and compositional studies of copper minerals, slags and slagged sherds, and metal droplets, demonstrate common principles of the Vinča culture copper smelting technology as well as sustained metallurgical activities that span c. 600 years.

The Balkans in the $5^{\text {th }}$ millennium BC are a particularly good case study for this, since the preference for brilliance, colour aesthetics, precision and geometric thinking dominates the material culture at the time (Chapman 2011). Well-executed craftsmanship, bold colours, dramatic shapes and symmetrical design can be encountered together in single objects in the $5^{\text {th }}$ millennium BC Balkan material culture. For instance, a high degree of standardisation is seen in the production of flint blades from the Bükk culture (Vértes 1965), remarkable geometric precision in the pottery of the Cucuteni-Tripolye culture (Washburn and Crowe 2004), spectacular craftsmanship in the gold-decorated vessels in the Varna I cemetery (Ivanov 1988), and outstanding painting techniques in the silver-sheen of graphite-painted pottery of the Karanovo-Gumelnița-Kodžadermen VI cultural complex (Todorova and Vajsov 1993). The preference for black in particular has been argued to be the major factor for the emergence of black-burnished ware, which was mainly favoured by the Vinča culture communities (Chapman 2006, 2007a). This colourful aesthetics of the Late Neolithic/Chalcolithic Balkans has its roots in the Mesolithic (Chapman and Richter 2009; cf. Srejović 1972), when such a view first constituted a central role in the culture of living and dwelling (Chapman 2007b). Therefore, the antecedent aesthetics was a crucial prerequisite for the introduction of copper and gold, both of which substantially contributed to the increase in the colour spectra of artefacts discovered predominantly in mortuary contexts (Chapman 2002). Importantly, this preference for colour and brilliance also goes beyond the primary region of interest here, and includes farming communities of Greece and northwest Anatolia.

The dazzling objects from the $5^{\text {th }}$ millennium BC Balkans are interpreted as serving one unifying role: to 'enchant' the audience with the technological craftsmanship involved in their production (Chapman 2011). Our particular interest here, however, is not to elaborate on the brilliance of finished artefacts (e.g. copper implements), but to understand the immanent and configurational properties of its production in the light of the attested preference for aesthetics among the Balkan communities in the $5^{\text {th }}$ millennium $\mathrm{BC}$, and in particular the Vinča culture population.

\section{Studied sites}


All four sites studied here belong to the Vinča culture, a Late Neolithic / Early Chalcolithic phenomenon which lasted for nearly a millennium in the largest part of the northern and central Balkans (e.g. Garašanin 1973; Chapman 1981) (Fig 1). We follow the periodisation of this culture developed by Milojčić (1949) based on distinctive ceramic typology, using alphabetic letters (Vinča A-D, with subdivisions). The estimated duration of the Vinča culture is c. 5400/5300-4650/4600 BC. The start of the Vinča A phase is recognised as c. $5400 / 5300 \mathrm{BC}$, while Vinča B starts around $5200 \mathrm{BC}$. The highest probability end for Vinča B1 is c. $5000 / 4950 \mathrm{BC}$; this marks the beginning of the Gradac Phase (Vinča B2), which probably lasted for c. 50-100 years. Vinča C lasts from c. 4900 to c. $4850 / 4800$ BC, while the abandonment of the Vinča culture settlements at the end of Vinča D falls around 4650/4600 BC (Borić 2009 , p. 234). The Gradac phase within the Vinča culture is particularly interesting, as it marks the occurrence of metal artefacts in the settlements, different settlement patterns and a change in material culture (i.e. decline in stone tool production, or different production trends in pottery making), amongst other observed changes (e.g. Garašanin 1995).

The Vinča culture material shows strong links to the contemporaneous Karanovo culture (phase III through to Kodžadermen-Gumelniţa-Karanovo VI) in Bulgaria, Precucuteni-Tripolye A in Moldavia and Ukraine, and Dimini in Greece. The most distinctive links, amongst others, are noticed in settling patterns, pottery production and the earliest industrial-scale production of metal objects in this part of the world. Almost five tonnes of extant copper implements from the $5^{\text {th }}$ millennium BC Balkans are known today, comprising an estimated 4300 objects in numerous museum collections (Chernykh 1978; Pernicka et al. 1997; Ryndina 2009). These artefacts occur in typologically distinctive shapes and are made from copper from several Balkan deposits (Schubert 1965; Kuna 1981; Pernicka et al. 1993; 1997).

The Balkans have also yielded the earliest evidence for copper exploitation in the world, at the mining site of Rudna Glava, spanning the entire duration of the Vinča culture from c. $5400 \mathrm{BC}$ until c. $4650 \mathrm{BC}$ (Borić 2009, p. 205-206). More recently, in the hinterlands of the Rudna Glava mine, at the site of Belovode in eastern Serbia, copper production evidence dated to c. $5000 \mathrm{BC}$ was uncovered. The provenance studies pointed at the potential exploitation of local sources, however not Rudna Glava (Pernicka et al. 1993; Radivojević et al. 2010, p. 2781 ff.). A longer gestation period of copper mineral use prior to copper smelting in the Vinča culture has been acknowledged in previous research (e.g. Chapman and Tylecote 1983; Antonović 2006), which is also demonstrated in case studies presented below (Radivojević and Kuzmanović-Cvetković 2014). Thus, the distinctive typology and quantity of metal artefacts, locally sourced ores and well-documented copper smelting evidence reinforced the idea of the independent origins of metallurgy in the Balkans (Renfrew 1969; Jovanović and Ottaway 1976; Radivojević et al. 2010).

Nevertheless, the sparse quantity of evidence for copper smelting in Belovode (c. $5 \mathrm{~g}$ copper slag were known prior to this research) (Radivojević et al. 2010, p. 2779) does not correspond to the vast amount of heavy copper implements, nor does it explain why the currently earliest metallurgy in the world happened in a location remote from the Near East, traditionally considered as the metallurgical heartland (see most recent review in Roberts et al. 2009). In order to address this question, the archives of several excavated Vinča culture sites were carefully searched for materials related to ancient metallurgy, and further metal production evidence was discovered from the settlement excavations of Belovode, Vinča-Belo Brdo, Pločnik and Gornja Tuzla. 

Belgrade. It covers an estimated c. 80 ha and the entire duration of the Vinča culture (Radivojević et al. 2010, p. 2778-9; Borić 2009, p. 209). Of particular importance here is the dating of the earliest stratigraphic evidence for extractive metallurgy, which starts at around $5000 \mathrm{BC}$, corresponding with the beginning of the Gradac Phase (Vinča B2). Copper mineral use occurs from the earliest horizons in this site (at c. $5350 \mathrm{BC}$ ), and continues throughout the entire occupation. Several kilograms of small-sized, possibly beneficiated copper minerals were uncovered thus far in excavations covering less than one percent of the settlement size; the greatest majority of these minerals are black-and-green and are the focus of research presented below. All materials related to metal production come from domestic contexts (Šljivar et al. 2006), and mostly from a single trench (No. 3). It includes copper slags, slagged ceramic sherds (see Table 1) and a copper metal droplet (M6). These were recovered from a wide and deep depression, mixed with several thousand fragments of ceramic sherds, bones and charcoal, and sealed by a layer of building waste. A single copper mineral (M10) from this trench studied here was found in the earlier building horizon and therefore precedes the copper smelting evidence. The other three minerals studied here also come from domestic contexts from trenches near Trench No. 3 (Radivojević and Kuzmanović-Cvetković 2014)(also Table 1).

Vinča-Belo Brdo lies on a plateau located on the right bank of the Danube, in the modern village of Vinča, c. $16 \mathrm{~km}$ southeast from Belgrade and covers 10 hectares on the loess terrace. The Vinča culture occupation started at c. 5300 BC (phase A) and ended around 4650-4550 BC (Borić 2009, p. 232). The Gradac Phase starts c. $4950 \mathrm{BC}$, similarly to the site of Belovode. All metallurgy-related materials originate from domestic contexts from the latest phase of occupation, Vinča D, dated between c. $4770 \mathrm{BC}$ and c. 4600 BC. The four samples studied here come from three artificially defined 'horizons' within Vinča D, and only a few meters apart from each other (Tasić 2003-2009). A copper mineral (Vinča 99) and a copper slag (Vinča 79) are the only two contextually directly related samples, discovered outside a dwelling feature and in the vicinity of two features with evidence of intense heating (Table 1). The two slag samples from Vinča (79 and 91) very likely represent debris from contextually different events.

The site of Pločnik is on the left bank of the Toplica river, $19 \mathrm{~km}$ west from Prokuplje in south Serbia and spreads across an estimated 100 ha (Šljivar et al. 2006). This settlement is best known for the discovery of 34 massive copper metal implements; a distinctive type of the earliest European hammer axes is called after this site. The highest probability for the start of the Pločnik occupation is around $5200 \mathrm{BC}$, and its end at c. $4650 \mathrm{BC}$. The terminus ante quem for the appearance of metal artefacts in Pločnik is set between c. 5040-4840 BC based on the dating of a structure that preceded the finding of a fragmented copper metal implement from recent excavations (Borić 2009, p. 214).

The use of copper minerals is evident from the early formation of this site: green lumps and pieces of copper minerals are found scattered across the settlement in the same manner as in Belovode, usually outside potential dwelling features in so-called workshop areas. Six copper minerals in total have been selected for this study (Table 1) two of which $(71,72 \mathrm{~m})$ come from the copper metal workshop in Trench No. 20, which belongs to the Gradac Phase (Šljivar and Kuzmanović-Cvetković 2009, p. 61). Other copper minerals $(51,54 \mathrm{~m}, 57,209)$ were sampled in order to provide information on their use in the earlier phases of Pločnik occupation. A copper metal droplet (Pločnik 52) originates from Trench No. 14, a few meters away from the metal workshop in Trench No. 20. It was uncovered on the floor of a collapsed burnt structure discovered in spits 10-11 and directly dated between c. 5040-4840 BC (Borić 

fragmented copper implement in this trench and represents the earliest dated metal artefact in the site of Pločnik.

Gornja Tuzla is a prehistoric settlement located on the terrace of the Jala river, which runs through the modern city of Tuzla, in Bosnia and Herzegovina, and spreads over an estimated 12-15 ha (Čović 1961). Two radiocarbon dates for the Vinča culture occupation published in the 1960s (Vogel and Waterbolk 1963, p. 183; Quitta and Kol 1969) and combined in OxCal (ver. 4.2b4) produce peaks around 4450 and 4410 cal BC (Radivojević 2012). However, the most recent excavations in this site yielded material dated a few centuries earlier (pers.comm. M. Vander Linden); it remains to be seen how these new dates relate to the earlier excavations that bore archaeometallurgical materials. The 1950s excavations of a single trench unearthed a collection of twenty metallurgy-related finds belonging to the later phases of the Vinča culture (Vinča C-D), of which three were selected for this study (Table 1). The collection includes a slagged ceramic sherd (GT 182a/b), a slag (?) sample (GT 194) and a copper metal droplet (GT 190), all discovered in domestic contexts of stratum II (Čović 1958), following on from the stratum III dated at c. $4400 \mathrm{BC}$.

Overall, the Vinča culture copper production evidence emerges in the beginning of the $5^{\text {th }}$ millennium BC, usually in the building horizon of the Gradac Phase. In Belovode and Pločnik, metal production activities can be dated from c. 5000 BC until the sites' abandonment at around c. 4650 BC. The production evidence from Vinča-Belo Brdo originates from three different domestic contexts dated to the end of the Vinča culture (Vinča D), between c. $4770 \mathrm{BC}$ and 4650/4550 BC, while the Gornja Tuzla samples can only be dated approximately to around c. $4400 \mathrm{BC}$. The copper mineral use, on the other hand, occurs from the very beginning of the occupation at both Belovode and Pločnik and pre-dates the metallurgical finds by a few centuries.

\section{Material and methods}

The research material presented here consists of 26 samples selected from c. 1000 relevant pieces stored in various collections in the National Museum and the Faculty of Philosophy (both in Belgrade, Serbia) and the Land Museum in Sarajevo (Bosnia and Herzegovina). This selection of samples complements five more copper slag samples from Belovode, previously studied by Radivojević (2007) and published in Radivojević et al. (2010). More than half of the selection presented here consists of copper slags, slagged sherds samples and metal droplets; the rest are copper minerals (Table 1). In comparison with the amount of technological debris (and slags in particular) in later prehistory periods, the sample size in this study is small. However, it targets a crucial period for the evolution of metallurgy in Europe, and as a coherent assemblage is unprecedented in size, quality and chrono-spatial resolution.

All copper minerals studied here are recognised as only potentially representing copper ores. Ore is understood as a culturally defined term referring to agglomerations of minerals from which the extraction of one or more metals is seen as a profitable action (Rehren 1997; Rapp 2009). The importance of this distinction of copper minerals in the context of metallurgical activities has already been recognised by Muhly (1989, p. 6), who noted that the presence of malachite at an archaeological site has little to do with 

iron metallurgy. In the Vinča culture, this non-metallurgical use of malachite manifests itself in a large bead industry, pre-dating copper smelting by up to c. 350 years (Radivojević 2012; Radivojević and Kuzmanović-Cvetković 2014).

Therefore, depending on the nature of activities involved in mineral processing, the term 'cold' is reserved to describe techniques borrowed from the lithic industry for bead making, while the term 'hot' denotes finds related to high-temperature processes of primary metal production (examples in Fig 2). The rationale for a distinction between bead mineral and malachite ore has been developed as part of the previous study on material from Belovode, which identified compositional (and provenance) differences between the two (Radivojević et al. 2010, p. 2784). Namely, the malachite beads from the sites of Belovode were made exclusively from pure green malachite, as were the beads from the sites of Pločnik and Vinča, too (Radivojević 2012; Radivojević and Kuzmanović-Cvetković 2014); this stands in contrast to black and green malachite used as ore in the Belovode smelting events. Thus, our working hypothesis for copper minerals coming from the Vinča culture sites with attested metal production assumes that those destined for bead making and copper smelting respectively would potentially differ in composition.

Slag is ideal for studying past pyrometallurgical activities because it typically contains information of all components contributing to its formation. Slag chemistry preserves information on physic-chemical conditions of the smelt, indicates which metal was extracted, the contribution of ores, associated clay, fuel ash, potential fluxes or even the design of s/melting installations (Bachmann 1982; Rehren et al. 2007). Early slags are typically found as either free pieces or attached to ceramic / installation walls. Often the slags from early periods were crushed in search for metallic prills for further refining (e.g. Ottaway 2001), making them archaeologically less visible.

A total of six free slag pieces are studied here in addition to those from Belovode published earlier, bringing the total slag assemblage from this site to just under 10 grams. They are vitrified, strongly magnetic and green-stained droplets, not exceeding $1 \mathrm{~cm}$ in length (Fig 3). They appear to have been highly viscous and very rich in copper metal; however, no visible signs of crushing in pursuit of metal prills were detected. These slag pieces outwardly resemble malachite, as a result of the corrosion of the copper metal entrapped in them. It is therefore possible that the green colour facilitated their recognition in the field excavations, leading to a biased recovery in favour of more copper-rich pieces and overlooking those without green staining. Thus, one could assume that more slag samples may have gone unnoticed in the dark brown soil in the field (Radivojević et al. 2010, p. 2779).

Slagged sherds are pieces of pottery with metallurgical slag spilt over them (Fig 3). In examples from Belovode, the concave surface is visually unaffected by exposure to heat beyond the initial firing temperature, as opposed to the convex surface, which is entirely or partially bloated and stained with a mass of green and grey appearance. Bloating often continues on the broken sections of the sherds, indicating an already fragmented state of the sherds when the heat was applied. The four slagged ceramic sherds from Belovode come from two consecutive spits (Nos. 5 and 6) in Trench No. 3. They are probably from two different vessels (Fig 3) and most likely originate from the same smelting event, judging by their clustering in the field. Our assumption is that these sherds were used to line a hole in the ground in order to insulate the smelting process against moisture from the soil and prevent the bottom of such an installation of running cold during the extraction process. Samples 30a and 30c are two body 

(Belovode 31a) and a vessel rim (Belovode 31b) were discovered together and most probably belong to the same ceramic vessel with c. $1 \mathrm{~cm}$ thick walls. Both samples are heavily vitrified and topped with a grey mass which contains small green-stained droplets. They have an almost triangular shape, with the longest section bloated from contact with temperatures higher than the initial clay firing (Fig 3).

A similar example comes from Gornja Tuzla. GT 182a is a $5 \mathrm{~mm}$ wide piece of light brown ceramic with green and grey stains on its bloated side; it was attached to a larger piece of slagged ceramic (GT 182b), which is $\mathrm{c} .1 \mathrm{~cm}$ thick, with inner rims and sections partially affected by heat exceeding the initial firing temperature (Fig 3). The heavily vitrified surface of an old break is stained with a green and grey mass, implying that this sample was used when it was already fragmented, and, as in Belovode, is not part of a crucible / container, but of a sherd-lined hole-in-the-ground smelting installation. The striking similarity of the Gornja Tuzla and Belovode slagged sherds suggests similar technological principles for the Vinča culture smelting installations.

Copper metal droplets selected for this study come from all four sites. In the sites of Belovode and Pločnik these samples were initially mistaken for copper minerals and selected only for their origin from 'metallurgical' trenches (M6 in Belovode and 52 in Pločnik). Their metallic structure was only revealed upon sectioning; they are included here due to the fact that they most likely demonstrate primary copper extraction, or smelting. Significantly, both samples stratigraphically precede metallurgical activities in Belovode (smelting slag) and Pločnik (the occurrence of massive metal implements) (Radivojević and Kuzmanović-Cvetković 2014). Copper metal droplets from the sites of Gornja Tuzla (190) and Vinča (83) are distinguished from other materials by their largely (copper) metallic core accompanied with inclusions and newly-formed phases (GT 190 only), the features of which classify both samples as products of smelting, rather than melting or refining. Metal artefacts and casting debris produced in these activities will be addressed in a sequel to this paper.

All materials were examined at the Wolfson Archaeological Science Laboratories at the UCL Institute of Archaeology, London, UK for their composition and microstructure (see Table 1 and Supplementary Material for the range of analytical techniques applied).

\section{Results}

The knowledge of the early metal worker would have centred on two major areas: correct identification and procurement of suitable minerals to smelt, and appropriate control over the smelting conditions to facilitate formation of metallic copper. Below we present the results of our analyses of copper-rich minerals found within the archaeological layers ('archaeological minerals', as opposed to newly-collected 'geological minerals' from ore outcrops), and of the smelting debris, followed by our interpretation of this data with regard to the level of knowledge evident from it. We use the compositional characteristics of the debris to explore the possible composition of the smelting charge, focussing on the difference of the slag composition from the composition of the ceramic sherds associated with the smelting. In particular we use the amount of typical fuel-ash oxides (potash, lime, magnesia, and phosphate) and of oxides associated with specific ore minerals, such as arsenate, phosphate, alumina, manganese and iron oxide, to identify 
any contribution to the slag formation other than the fused ceramic and predominant copper oxide (mainly originating from what we believe was malachite ore). Finally, microstructural examination complements our understanding of the formation of particular phases and aids interpretation of the knowledge involved in the metal smelting.

\subsection{Archaeological minerals}

The copper minerals form two distinctive groups: oxide and sulfide minerals. The oxide minerals are black-and-green, a colour feature microscopically revealed as two distinctive mineral phases: optically bright green crystals and grey oolithic structures (excluding Pločnik 71) (Fig 4). The bright green crystals are mostly copper oxide (probably present as carbonate) with minor concentrations of manganese, zinc and iron (up to $0.5,1.5$ and 0.5 at $\%$, respectively). Oolithic formations appear optically grey and dark and exhibit a more complex chemical structure, which is markedly similar throughout all but one sample, Pločnik 71. They all (excluding Pločnik 71) have copper and manganese contents in ratios varying from 1:1 to 2:1 in favour of copper (Radivojević 2012). The ternary plot of $\mathrm{MnO} / \mathrm{ZnO} / \mathrm{CuO}$ (Fig 5) illustrates the striking compositional similarity of oolithic formations in all studied minerals: they cluster halfway through the $\mathrm{Cu}-\mathrm{Mn}$ axis, with major fluctuations noted in zinc oxide levels. Belovode M10 and Pločnik 71 are presented as outliers, due to high manganese and high copper contents respectively.

Three copper minerals with relevant sulfur content were found at Belovode $(3,33 b)$ and Pločnik (72m). Besides copper oxide / carbonate, these contain phases compositionally closest to covellite (CuS, samples 3 and $33 \mathrm{~b})$, chalcocite $\left(\mathrm{Cu}_{2} \mathrm{~S}\right.$, sample $\left.72 \mathrm{~m}\right)$, pyrite $\left(\mathrm{FeS}_{2}\right.$, sample $\left.72 \mathrm{~m}\right)$ and sphalerite $(\mathrm{Zn}(\mathrm{Fe}) \mathrm{S}$, sample $72 \mathrm{~m}$ ). Macroscopically, these samples appear less granular than the black-and-green oxide minerals, although they too have distinctively coloured cross-sections in shades of green and grey with metallic lustre (sample 3 in Fig 4).

The examination of oxide copper minerals from different Vinča culture sites spanning circa 800 years showed that during this period a pattern of selecting manganese-rich batches can be observed. They differ from the 'pure' malachite used for bead making in their common black-and-green appearance and similar compositional ratios of copper to manganese, which is striking as a particular selection choice throughout the Vinča culture (Radivojević et al. 2010; Radivojević 2012). For technological and cultural reasons to be explored below, these minerals were selected over others available in nature, indicating an awareness of their properties throughout c. 800 years.

On the other hand, the presence of sulfide copper minerals in the $5^{\text {th }}$ millennium $\mathrm{BC}$ Chalcolithic settlements is noteworthy, as it is rare and still not well documented in this period. Significantly, both oxide and sulfide copper minerals occur together in the studied sites and were distinctively coloured in green and black / grey, by their manganese or sulfur content. It also implies that at this very early stage of pyrometallurgy copper metalworkers from Belovode and Pločnik were experimenting with different kinds of green and black minerals, and that the outer appearance of these minerals played a significant role in the selection process. 


\section{2 (S)melting: Production Debris}

All analysed Vinča culture copper slags, barring GT 194, are similar in their macro- and microstructure. A common feature of these slags (free slag samples and slagged masses on pottery sherds) is that they solidified from an almost fully liquefied state, while still being heterogeneous. Due to this heterogeneity, we focused on the composition of slag glass matrices (relatively inclusion-free), in order to identify the smelting charge components throughout the studied evidence.

The glassy slag matrices in all studied samples are predominantly made of silica, alumina, lime, iron, and copper oxides, which together amount to around $86 \mathrm{wt} \%$ on average of the slag glass constituents (Tab 2). These are followed by phosphorus, potash and magnesia, which amount to another 6-14 wt $\%$ on average, and largely originate from the fuel ash intake during the slag formation. Besides copper, which undoubtedly comes from the ore, the other 'ore elements' are manganese, cobalt, zinc, arsenic, tin, and antimony, with totals ranging from as low as $0.5 \mathrm{wt} \%$ in a slagged sherd (31a) to the maximum of 12.3 $\mathrm{wt} \%$ in a free slag sample (136). In comparison with the typical Vinča culture ceramic from these sites (Tab 2), the slags (including slagged areas on sherds) are characterised by a slightly elevated iron content, and more significantly, higher lime levels. The elevated lime levels are usually taken as fuel ash contamination, however, this oxide can also come from the ore body, as elaborated below (see Fig 10). The clearest indication that these slag glasses are not just fused ceramic bodies is the distinctive ore component: the slag matrices from Belovode and Vinča are rich in manganese and zinc, while the Gornja Tuzla slag bears a unique arsenic-tin-antimony signature.

The ternary plot of components taken to represent common ceramic $\left(\mathrm{SiO}_{2} / \mathrm{Al}_{2} \mathrm{O}_{3} / \mathrm{TiO}_{2}\right)$, fuel ash $\left(\mathrm{CaO} / \mathrm{MgO} / \mathrm{P}_{2} \mathrm{O}_{5} / \mathrm{K}_{2} \mathrm{O}\right)$ and ore $\left(\mathrm{FeO} / \mathrm{MnO} / \mathrm{ZnO} / \mathrm{NiO} / \mathrm{CoO} / \mathrm{As}_{2} \mathrm{O}_{3} / \mathrm{SnO}_{2} / \mathrm{Sb}_{2} \mathrm{O}_{3}\right)$ components in the glassy slag matrices (re-cast as $\mathrm{Cu}$-free oxides) in Fig 6 illustrates the difference in composition of these matrices from the average Vinča culture ceramic composition. The most distinctive ones are the group of free slag samples from Belovode and Vinča, which cluster closer to the ore elements corner, along with a few readings from the Belovode slagged sherds. On the other hand, the strongest intake of ceramic and fuel ash contamination is noticed in the Belovode and Gornja Tuzla slagged sherds (including GT 194), with only a few readings from the free slag samples from Belovode and Vinča close to the typical ceramic composition. The glassy matrices are rich in silica and alumina, which explains why the slags are highly viscous, despite the significant input of oxides such as lime, iron and copper oxides (cf. Davenport et al. 2002, p. 63). One of the most important observations is that copper smelting technology exhibits a high level of similarity throughout Belovode, Vinča and Gornja Tuzla, illustrated by the strong cluster in the $\mathrm{SiO}_{2} / \mathrm{Al}_{2} \mathrm{O}_{3} / \mathrm{TiO}_{2}$ corner of the diagram.

Another strong similarity in the smelting technology across the sites of Belovode, Vinča and Gornja Tuzla is observed in the microstructure of the slags (Fig 7). Copper oxide-based compounds dominate in all samples. These are commonly associated with delafossite, spinels and leucite, with sporadic occurrence of pyroxene, olivine, wüstite and iscorite (Table 2), which are usually present in areas of slag glass crystallisation. Their presence indicates the variable redox conditions as well as variations in ore composition, both of which will be discussed in detail below. Only few residual, partially decomposed quartz grains were discovered in free slag samples, but are a common feature of slagged sherds. Other than occasional quartz grains, there is little evidence of residual minerals except for the 'drossy' areas, which due to c. 7000 years of post-depositional processes, are difficult to identify as either residual ore or 
newly-formed phases. An exception to the rule is sample GT 182a, where residual minerals rich in arsenic, antimony and tin were identified in a glassy slag matrix (Fig $7 \mathrm{~h}$ ).

Sample GT 194 yielded scarce information concerning production in the slag matrix; however, the enrichment with iron (Table 2) suggests that this was possibly copper melting debris (cf. Craddock and Meeks 1987). Another aspect supporting this supposition is that no other phase - apart from a charcoal piece and the copper metal entrapped in it - was detected in GT 194, which stands in stark contrast to the smelting evidence from this (and other) Vinča culture sites presented here. Hence, GT 194 most likely represents melting slag fused with corrosion products and a piece of charcoal.

The working temperatures of the smelting systems across all three sites is estimated to have been just over $1083{ }^{\circ} \mathrm{C}$, according to the fully molten state of copper metal prills embedded in them. This was evidently not high enough to make the slags analysed here less viscous and more homogeneous (cf. Davenport et al. 2002, p. 59-60). Noteworthy is the virtually 'slagless' smelting in Belovode and Pločnik, judging by the evidence in samples M6 and 52 (Fig 8). They both contain copper metal and residual primary copper minerals (chalcocite and covellite); the latter probably accompanied secondary copper minerals selected for smelting. Interestingly, these samples did not contain iron or manganese, which are crucial for the generation of slag.

\subsubsection{Variations in Metal Making Recipes}

The discussed 'consistency' of the $5^{\text {th }}$ millennium BC copper production evidence, however, includes noticeable differences in slag microstructure, choice of fuels and ores. As a result, compositional discrepancies among slag samples stem from constraints imposed by the choice of ingredients and redox conditions of the metal production process, both of which are addressed below.

The redox conditions in the studied slags are indicated by the presence of newly formed crystalline phases (Table 3). Since the co-occurrence of cuprite, delafossite and iron spinels dominates the slag samples, it appears that partially oxidised atmosphere prevailed, which was sufficient to smelt copper (cf. Elliott 1976). Relevant levels of iron in copper metal droplets Gornja Tuzla 190 and Vinča 83 suggests that these also formed during primary metal extraction (cf. Craddock and Meeks 1987). These redox conditions suggest that the overall gas atmosphere was slightly oxidising / moderately reducing, which resulted in producing successfully copper metal and the formation of heterogeneous slag in the sites of Belovode, Vinča-Belo Brdo and Gornja Tuzla.

Samples from Belovode, the largest assemblage of production debris in this study, deserve particular attention due to their clustering in a single trench in the field. The cluster of samples Belovode 30a/c, 31a/b, 131, 134, 136, including M21, M22a/b, M23 (Radivojević et al. 2010), in spits 4-7 in the 'metallurgical' Trench No. 3 (Table 1) indicated that they probably represent evidence of a single smelting episode. This assumption is further strengthened by the compositional analyses, which indicate strong correlations in the ore signature ( $\mathrm{Mn}$ and $\mathrm{Zn}$, Table 2). It follows that slagged sherds 30a/c and 31a/b most likely lined the smelting hearth for what appears to be a single smelting episode that resulted in the formation of mentioned samples. The remaining samples (M20, M6) differ from these compositionally, structurally and contextually, for which reasons they most likely represent two additional smelting events in this trench. 

2). Manganese oxide is known to facilitate the formation of a melt under the lower operating temperatures than those required when, for instance, iron oxide is present in the system (Huebner 1969, p. 463, Fig. 3; Heimann et al. 2001, p. 233). Therefore, the advantageous chemical-physical properties of manganese oxides enabled an easier reduction of copper ores to metal and slags within less-controlled smelting environments. This particular feature of manganese-rich ores was probably known to the ancient smelters based on the observation that a particular type of ores (as in particularly coloured) would be more efficient to smelt. This beneficial property of manganese oxide for copper smelting was later also recognised in the mid- $4^{\text {th }}$ millennium BC smelting site of Wadi Fidan 4 in Faynan in Jordan (Hauptmann 2007, p. 195, 234). Macroscopically speaking, manganese appears in the Balkans as a black phase in paragenesis with green copper minerals (mostly malachite), which makes it a distinctively coloured blackand-green ore.

The ore signatures in the Vinča culture production evidence can be recognised in all identified slag samples. The most informative phases are iron-rich spinels, copper metal, glassy matrices, and a residual phase in GT 182a. Since each of the ore elements partitions differently during smelting, the combination of data obtained from all identified phases is expected to provide the most comprehensive information about the compositional signature of the ores used to make metal in Belovode, Vinča-Belo Brdo and Gornja Tuzla.

Iron spinels were found in all production evidence except in GT 182a and Belovode 30a/c (Table 4). Besides iron and copper oxides, manganese oxide is another major constituent (barring GT 190). The iron spinel compositions suggest that the ores used for smelting in Belovode and Vinča differ from those used at Gornja Tuzla, although the consistent presence of cobalt and zinc in all samples (average concentrations of c. $2 \mathrm{wt} \%$ each) suggest that the smelted ores could have been part of the same mineralisation or metallogenic belt in the Balkans. The type of ore smelted in the Gornja Tuzla event is best represented by a residual phase encountered in sample GT 182a (Fig 7h). It appears as rich in phosphorus with relevant concentrations of arsenic (reaching 3.4 at \%) and antimony, tin and tungsten $(0.1$ at\%-0.2 at\%). The closest mineral match to this phase would be arsenic-rich apatite (Fig 9), which was possibly included with the malachite to make copper in the site of Gornja Tuzla.

Trace element concentrations in copper metal prills consistently include nickel and gold throughout all metal phases, with the strongest signature of the former at c. 960 ppm mean in Belovode 131 (Tab 5). Arsenic levels are most significant in GT 182a, at $1250 \mathrm{ppm}$, which are present in conjunction with Sb and S in both GT 182a and Belovode 131, and with c. 1 wt\% of cobalt in the latter. The occurrence of antimony and arsenic might point at the sporadic presence of fahlerz or other complex minerals in the smelting charge in the sites of Belovode and Gornja Tuzla, potentially collected as part of the primary mineralisation together with the green copper-rich minerals.

Sulfur concentrations are variable throughout, with the highest values in GT 190 at c. 740 ppm. Its presence demonstrates that some of the primary copper ores were potentially included with the secondary, green copper minerals. This is particularly true for the signature of GT 190, where the sulfur content with significant zinc and iron dominates the trace element signature of the copper metal phase. Manganese, on the other hand, is only rarely encountered in the copper metal phase, and its presence in Belovode 131 implies that the smelted ores were extremely rich in this element (cf. Tylecote et al. 1977, p. 313, Table 

the iron spinel data, that similar ores were used in the sites of Belovode and Vinča, while Gornja Tuzla craftsmen exploited a compositionally distinctive ore.

The glassy slag matrix is another reliable indicator of the ore signature in the production evidence (Table 2). The three ternary diagrams below illustrate the close correlation of slag glass composition with the potential ores used for metal making in all three sites (Figs 10-12). The geological ores matched on these diagrams show the closest compositional correspondence with the combination of metal oxides in the slag samples. For Belovode data we used the ternary cluster of $\mathrm{K}_{2} \mathrm{O}-\mathrm{CaO}-\mathrm{MnO}$ in order to distinguish between the ore and fuel ash signature (Fig 10); the lime readings in these matrices were too high to be solely due to the fuel ash intake, and our assumption that they may have come additionally from an ore source seems plausible. The alignment of readings along the $\mathrm{K}_{2} \mathrm{O}-\mathrm{CaO}$ axis indeed presents a potential fuel ash signature (beech ash data after Jackson and Smedley 2004, p. 39, Table 4), while the strong cluster of a selection of glassy matrix data along the $\mathrm{CaO}-\mathrm{MnO}$ axis demonstrate the use of manganese-rich blackand-green copper minerals. The slag glass signature from Vinča 79, besides the manganese intake (Table 2), shows also increased iron and phosphorus concentrations, which match closely the composition of blue/green phosphate vivianite $\left[\mathrm{Fe}_{3}\left(\mathrm{PO}_{4}\right)_{2} \bullet 8 \mathrm{H}_{2} \mathrm{O}\right]$ (Fig 11). It therefore indicates the likely combination of ores smelted at this site for this particular event; for Vinča 91 we assume that only a combination with black-and-green manganese-rich copper ores was used. In Gornja Tuzla, the slag glass matrix plots near the projection of secondary minerals of the phosphates/arsenates family such as scorodite $\left(\mathrm{FeAsO} \mathrm{O}_{4} \cdot 2 \mathrm{H}_{2} \mathrm{O}\right)$, strengite $\left(\mathrm{FePO}_{4} \cdot 2 \mathrm{H}_{2} \mathrm{O}\right)$ and arthurite $\left(\mathrm{CuFe}_{2}\left(\mathrm{AsO}_{4}, \mathrm{PO}_{4}, \mathrm{SO}_{4}\right)_{2} \cdot 4 \mathrm{H}_{2} \mathrm{O}\right)(\mathrm{Fig} 12)$.

The striking detail that underlines the chemistry of ores smelted at these sites is their dominant colour: whatever the exact minerals that were present in the ore charge, they most likely had strong colours in the range of green/blue (i.e. vivianite, arthurite, apatite, scorodite), and violet (i.e. strengite), in addition to black and green manganese-rich malachite (Belovode and Vinča only). With regard to the Gornja Tuzla evidence, this may have been the case as well in the selection of copper-based ores for smelting. For instance, scorodite is the most common weathered mineral originating from the primary arsenic ore, arsenopyrite. Interestingly, the weathering of arsenopyrite results in green/blue scorodite and red/black goethite $[\mathrm{FeO}(\mathrm{OH})]$ (Murciego et al. 2011, p. 594). Thus, the allure of green and dark/black minerals found together in the landscape could have been a decisive factor for the copper metalworkers not only in the sites of Belovode and Vinča, but also in the site of Gornja Tuzla, too. The Bor district in eastern Serbia is a possible source for all these minerals in paragenesis with copper and iron ores, which is not too distant from the studied sites (Belovode being the closest at c. $50 \mathrm{~km}$ distance). It contains massive sulfide deposits of cuprous pyrite, with rich primary and secondary copper minerals (Sillitoe 1983; Janković 1990) and polymetallic enrichments that makes the occurrence scorodite and strengite, and other phosphates such as apatite and vivianite very likely (see Supplementary materials).

\section{Discussion}

The results presented above demonstrate the presence of sustained metallurgical activities from c. 5000 to c. $4400 \mathrm{BC}$ in the Balkans. The studied assemblage, although small in size, is unprecedented in terms of resolution and quality, and as such offers an exclusive insight into the origins of metallurgy in Eurasia. 


\section{Green Minerals, Tainted Ores}

The compositional analyses indicate a particular preference of Vinča metal metalworkers for black-andgreen copper ores. The presence of these distinctively coloured ores at the site of Pločnik may be suggestive of smelting activities taking place in this settlement as well. Besides mineral Pločnik 209, which is abundant with manganese, sulfur-rich copper mineral Pločnik $72 \mathrm{~m}$ exhibits a similar colour code, which is black/dark and green. This is important since mineral $72 \mathrm{~m}$ comes structurally and compositionally closest to the one smelted to produce copper metal droplet Pločnik 52. Thus, although no slag has yet been discovered in this site, analysis of sample Pločnik 52 suggest the existence of a smelting event, which probably included black/dark and green ores. In a similar manner, copper metal droplet M6 from Belovode illustrates a comparable event of smelting ore that was probably structurally similar to the one identified in samples Belovode 3 and 33b; hence, this event most likely also included distinctively coloured black and green ores. Importantly, both events (52 and M6) at the sites of Pločnik and Belovode occur stratigraphically before the metallurgical events at both sites; while Pločnik 52 originates from the context preceding the earliest known copper implement from this site (Borić 2009, p. 214), Belovode M6 comes stratigraphically ahead of the earliest known smelting event at this settlement (Radivojević et al. 2010; Radivojević and Kuzmanović-Cvetković 2014). These events are significant because they document events in which dark/black and green minerals were smelted possibly prior to the 'slagging' metallurgy encountered from c. 5000 BC.

The field evidence from both Belovode and Pločnik suggests that black-and-green minerals appear from the earliest layers of occupation (Radivojević and Kuzmanović-Cvetković 2014); however, no copper metal artefacts are known from these sites prior to c. $5000 \mathrm{BC}$. It remains to be seen in future investigations of Belovode what other uses of these black-and-green minerals existed in pre-5000 BC if not for copper smelting. Noteworthy is that we find only pure green and black-and-green minerals in the studied sites; this is particularly startling for Belovode, located in the heart of the copper-rich eastern Serbia, where other geologically similar choices were available. Significantly, this dual selection of copper minerals also appears to be a pattern during the Early Neolithic occupation at the Danube Gorges sites of Lepenski Vir and Vlasac, dated to the late $7^{\text {th }} /$ early $6^{\text {th }}$ millennium BC, where both pure green and black-and-green (thermally unaltered) minerals were discovered in the domestic contexts (Radivojević 2012).

It has already been mentioned that malachite beads from the sites of Belovode, Pločnik and Vinča were made exclusively from pure green malachite, in contrast to the black-and-green ore linked to copper smelting. Hence, the dichotomy of pure vs. tainted copper minerals in the archaeological record across the studied Vinča culture sites could indicate that the decisions made towards their selection were guided by their colour, implying the existence of an awareness that these coloured minerals of a particular character produced a good result. To illustrate, the majority of c. $7 \mathrm{~kg}$ of copper minerals recovered from the excavations of Belovode (until 2009) were of black-and-green appearance, which speaks of this particular technological preference, but also of the scope of experimentation / intended production of copper in this site. In terms of technology, the dual principle applies here as well: 'cold' techniques were employed for bead-making, borrowed from the lithic industry, while 'hot' high temperature treatment of black-and-green tainted copper minerals turned them into ores that produced shiny droplets of copper metal. 
Although it is not clear from the analyses whether black and green minerals were selected separately or as a mixed ore, the conclusion that emerges from the analytical discussion is the presence of a common knowledge regarding the suitability for smelting of distinctively coloured mixed minerals. This stands in contrast to the uniformly green pure malachite selected at the same time for bead production. We are, however, not arguing that the pure green malachite was not used for smelting as well, but rather that the black and green minerals were intentionally selected for high-temperature treatment in the sites of Belovode, Vinča and Gornja Tuzla, for more than half a millennium, as a sole or a combined charge for the early copper extraction. The importance of the colour factor has also recently been argued for the emergence of the earliest tin bronze artefacts in the Balkans (Radivojević et al. 2013), implying that the correct combination of ore colours drove the experimentation phase during the early metal production in this region (Radivojević forthcoming).

The dual selection principle in separately processing pure and tainted copper minerals for different purposes is without parallel at the time. It indicates the recognition of immanent properties of these minerals and their use for a particular purpose to meet historically specific demands. During the period of at least c. 600 years, the Vinča culture copper metalworkers practiced smelting of black and green copper ores, solely or in combination with pure green copper ores, which constituted the smelting charge most suitable to yield metal under variable conditions of the smelt. Hence, the success of copper smelting using such ore reinforced the preference for black and green ores among the Vinča culture metalworkers. Such knowledge was crucial for a successful transformation of ore to metal, and was accompanied by another transformation, that from the perception of black and green copper minerals into black and green copper ores.

This argument takes the debate of the origins of metallurgy in a single place somewhere in the Near East beyond the discussion of the 'earliest' dates, as the key evidence appears to be the preference for a particular combination of black and green ores in order to transform them into metal. The current state of research in the Near East has not thus far yielded evidence comparable to the one in the Balkans (Radivojević et al. 2010, p. 2776 ff.), particularly when it comes to investigating types of minerals being selected for metal smelting. The appearance of black and green minerals in the archaeological record of the Balkans around a millennium prior to the earliest recorded smelting events indicates a pre-existing knowledge of these minerals and probably experimentation with their material properties. Thus, the consistent selection of black and green minerals, which turned into ores around $5000 \mathrm{BC}$ speaks of a unique technological trajectory of Balkan metallurgy, which reinforces assumptions of its independent evolution (cf. Renfrew 1969; Jovanović and Ottaway 1976; Radivojević et al. 2010).

Although the original reasons for applying heat (as in smelting) to copper minerals are not yet well understood, a clue for such a decision may be found in experimental reconstructions of copper smelting events. The primary author recently took part in a copper smelting experiment and recorded the moment when the flames of this process went green (Fig 13). This happened just after a handful of malachite was thrown onto a bed of charcoal heated up in a small bowl furnace. Thus, it could be assumed that early attempts to smelt copper were potentially driven by curiosity to explore properties of materials that burned with green flames, and that knowledge of copper smelting evolved in the context of appreciation of the aesthetics of coloured flames. Noteworthy is that some of the minerals mentioned in this article from the class of phosphates (vivianite) and arsenates (scorodite) release blue and green flames when set on fire (Dana and Ford 1922, p. 608, 610). This particular feature of ores used for early smelting may 
have been yet another sensorial aspect included in the early metal production. 7000 years later the property of minerals to colour flames was still being used as a field analytical tool in mineralogy and ore prospection (Henglein 1962).

By and large, and with regards to the knowledge of copper and other, potentially geologically associated, colourful minerals, the metalworkers at the time must have recognised the immanent properties of these raw materials. This recognition most likely evolved over the course of at least several centuries prior to metal extraction, and was based on developing awareness of the most suitable ores due to their colour, smell, taste, behaviour under heat treatment, geological association with other minerals or their place in the landscape. 'Painting' the ore charge in black for the process of material transformation was an unprecedented configurational combination of immanent properties of these ores at a particular time with a particular knowledge that defined the historically unique time for the invention of metallurgy in the Balkans.

\section{A Tale of Three Slag 'Heaps'}

The results of our analyses allow for a tentative reconstruction of the metal production technologies used at three different Vinča culture sites: Belovode, Vinča and Gornja Tuzla. Both macro- and microanalytical approaches demonstrate the practicing of copper smelting throughout c. 600 years altogether, with startling similarities in the level of expertise and technological choices, but with clear differences in the composition of the ores smelted. Particularly interesting is the fact that the technological principle of the Vinča culture production evidence is not chronologically sensitive. The estimated chronological sequence of these finds starts with the Belovode slags at c. 5000 BC (until c. 4600 BC), which for c. 200 years overlaps with the Vinča-Belo Brdo evidence (c. 4800-4600 BC). The Gornja Tuzla copper smelting took place up to 200 years after both Belovode and Vinča were abandoned (c. 4400 BC). It seems that over more than half a millennium of evidence for copper production in the Vinča culture, the principle of copper smelting remained consistent.

Regardless of how insignificant the small amount of slag from these sites may appear, it fits the overall picture of rather ephemeral production evidence in the pre-Bronze Age metallurgy (Craddock 2001, p. 152). To illustrate, the early slags of the $5^{\text {th }}$ and early $4^{\text {th }}$ millennium BC mostly look the same: they hardly weigh more than a few grams each and reach nut-size at most (cf. Hauptmann 2007, p. 158); thus, it is not surprising that the earliest documented slags sit on the low end of the size of slag 'heaps' identified thus far (Bourgarit 2007, p. 4, Table 1). The Vinča culture smelting installations debris thus fit well in this 'ephemeral model' of the Chalcolithic metallurgy. Slagged sherds at both Belovode and Gornja Tuzla suggest the presence of a hole-in-the ground installation lined with broken pottery. However, none of them was discovered related to a hearth or a similar detectable feature in the field. Hence, it may be hypothesised that the copper smelting installations at both sites were too ephemeral to survive c. 6000-7000 years of post-depositional processes, and only took the form of shallow indentations in the soil, lined with ceramic sherds. Such installations were possibly run by using blowpipes or bellows, where normally 5-6 blowpipes would suffice for bringing the temperature to around $1100-1200{ }^{\circ} \mathrm{C}$ (cf. Rehder 1994, p. 221). 
The same is true for crucibles, which are also absent from the field record in the Vinča culture sites, although their presence has to be assumed given that they would have been needed for casting the thousands of heavy metal objects known from this period. Interestingly, the casting moulds for the vast number of metal implements from this period are also absent from the archaeological record (Kienlin 2010, p. 42 ff). The only two pre-Bronze Age (smelting) crucibles discovered in the Balkans originate from mid to late $5^{\text {th }}$ millennium BC Bulgarian sites of Chatalka and Dolnoslav (Ryndina et al. 1999), and are not culturally related to the Vinča culture phenomenon.

Experiments have shown that the slags needed to be crushed in order to extract copper metal globules (Ottaway 2001); however, judging by the evidence presented here, this does not appear to have been the case for the Vinča culture slags. One of the explanations may be that the crushed slags were indeed lost in the field, or that the Vinča smelters were successful in producing more liquefied slags, which facilitated a finer separation of copper metal without the need for crushing.

A particularly intriguing question concerning the early copper smelting operations is how productive they were at this stage. The models based on the Late Bronze Age and later metallurgy assume that large quantities of slag would usually form on top of metal collecting at the lower bottom of the smelting reactor (e.g. Bachmann 1982; Maldonado and Rehren 2009). Nevertheless, experimental copper smelting carried out in smaller containers in Timna (Israel) did not result in the formation of a plano-convex ingot but mainly in copper metal in globular form (Tylecote and Boydell 1978, p. 46). Tylecote and Boydell (1978, p. 49) further argue that smelting in a smaller furnace, which can take up to $5 \mathrm{~kg}$ of smelt charge (ores and fluxes), yielded the most satisfactory results in terms of productivity and working conditions, as opposed to the larger smelting reactors which could run cold at the bottom and hence hinder the production process. On this example, we can see how understanding immanent properties of copper ores and limitations of the installation designs can help reconstruction of the early smelting processes. In other words, it is the realisation of, and operation within immanent constraints of metal making ingredients within a given technological context that shaped the way an object was crafted and in effect advanced the knowledge of its production.

Although these modern experiments were run in furnaces built after Early Iron Age models from Timna, it is tempting to draw parallels between these and the proposed Vinča culture 'hole-in-the-ground' smelting installations, based on the suggested production potential of small smelting reactors. At the early stage of metallurgy, a much cleaner ore would have been used, resulting in a 'slagless' or nearly slagless metallurgy. Depending on the relative proportions of (slag-forming) dark components in the ore and pure green mineral, a large amount of copper may have formed with just the smallest quantity of slag; this is the favoured scenario in our study. Given this scarce evidence one could assume our samples survived as an exception rather than a rule to the early metal extraction process; however, if they were an exception, they would not have consistently occurred in all three studied sites. Furthermore, the studied slags come from the 'backyards' of only a few of the excavated dwelling structures and pits in our settlements, and the observed pattern may have been caused by a particular model of organisation of metal production that we cannot reconstruct at the moment. 

installation as a small, efficient, pottery-lined hole-in-the-ground. In the absence of any other data indicating that the Vinča culture metallurgy was not only household-based, this production evidence stands as the only type of debris for making copper metal during this period, and, as such, may be taken as representative of the 'true' nature of the process at this time.

Therefore, regarding the large quantity of extant copper metal artefacts in the Vinča culture, the copper for their making was thus most probably produced in countless individual episodes, within small, household-contained workshops. Although the Vinča culture production evidence studied here represents only a very few of these episodes, the replication of the production pattern across all three sites within different occupational sequences indicates that the level of mastery remained relatively unchanged and potentially stagnant across an estimated period of six centuries. Significantly, the innovative variable in replicating these smelting recipes was the choice of colourful ores in the right proportion with the black component. These black-and-green ores thus remained a smelting 'recipe' ingredient prone to the greatest variation and creativity within an otherwise consistent smelting environment. The process slowly evolved into smelting of more complex copper ores only towards the end of this culture, as attested by the Gornja Tuzla example, containing small but significant amounts of arsenic, antimony, and tin. This trajectory towards 'natural alloys' is illustrated by the occurrence of complex tin bronzes in the late Vinča culture, which can also be linked to the use of colourful complex copper-tin bearing ores (Radivojević et al. 2013). 
The combination of black-and-green ores in the early Balkan metallurgy emerges as the main argument for building explanatory models for its independence, as well as supporting claims about its unique technological trajectory, which was without parallel at the time. Why was the early copper production 'painted black'? The slag-forming behaviour of the black and green manganese-rich copper ores led to slags that were more reliably liquid under variable redox conditions, which serves to facilitate the metal extraction process. Also, the colour preference for black in the context of the Vinča culture contributes significantly to the overall interpretation of this particular aesthetic preference. Glossy surfaces of blackburnished ware and the dark silver sheen of graphite-painted pottery illustrate the aesthetic context at the time of the emergence of metallurgy in this part of the world. While we are reluctant to draw technological parallels between black-burnished pottery and metal production (despite the fact that both resulted in shiny objects), the specific aesthetical desire for black could have encouraged a discovery of another 'colourful medium' (cf. Chapman 2007a, p. 70): tainted ores with a capacity to transform into brilliant artefacts.

The black in the smelting ore charge could have thus represented a supernatural, a power without which the extraction of metal would not have been successful. 'Painting' the green ore charge in black could have activated the 'enchantment' of material transformation, the one that provides means for tainted, 'dirty' materials to transcend into much sought-after radiant objects at the time. The sensory and physical aspects of this transformation process must have been crucial for leading the operation to its successful end. Colours of burning ores or flames were the best indicators of the process flow, the navigation of which demonstrated the configurational knowledge of metalworkers at the time. Thus, the successful transformation of ore to metal was a factor of immanent properties of input and output components, immanent behaviour of the smelting process, and most importantly, a set of configurational skills mastered at the time of inquiry.

Besides demonstrating that the Balkan metalworkers had their own technological trajectory of mastering metal production, the presented data also shows that the recipe for metal making was culturally shared among these metalworkers and transmitted during c. six centuries of Vinča culture metal production. The continuity and consistency of copper smelting technology suggest that such knowledge was passed as an 'all-in-one' package within a strong and conservative tradition. This conservative tradition suggests that the transmission of knowledge was kept within a particular lineage of craftspeople, where skills were most likely passed from a parent to the same gender offspring (Shennan and Steele 1999). The reasons for cooperation between different Vinča culture settlements could thus possibly be sought in their belonging to large webs of kinship (e.g. clans) (cf. Kienlin 2010).

The size of a learning network has been shown as very important when it comes to skills transmission in traditional and prehistoric communities (Shennan 2001; Henrich 2004; Roux 2008; Powell et al. 2009). As every innovation, the spread of metallurgical skills in the Vinča culture required a sufficient number of learners, which according to the consistency of selection practices of black-and-green ores and copper smelting technology throughout c. 600 years, appeared stable during this period. The learning network of Vinča culture metalworkers ceased to exist in the sites of Belovode, Vinča, Pločnik and Gornja Tuzla around the mid $5^{\text {th }}$ millennium BC, along with the end of the Vinča culture mysteriously marked by an abandonment of these and other settlements in modern day Serbia. Nonetheless, judging by the continued production of massive copper implements across the Balkans throughout the entire $5^{\text {th }}$ millennium $\mathrm{BC}$, this learning network possibly continued to grow in other parts of this region. A discussion of the 

to be addressed in future publications.

Extractive metallurgy, as any other idea, had multiple origins. In addition to other places, it found fertile ground to progress within the Vinča culture phenomenon. It evolved through experimentation, demonstrated by the presence of black-and-green minerals and 'slagless' extraction prior to the earliest documented smelting, but also by the selection of compositionally different yet similarly coloured ores. The Vinča culture metalworkers also developed an understanding of the smelting process and applied it in a consistent manner throughout the centuries of practice. The Vinča culture communities must have had social institutions in place to provide logistics for the distribution of metal implements to markets that desired these objects (Radivojević forthcoming). Nearly five tonnes of extant copper metal implements discovered in domestic, ritual and/or funerary contexts across the Balkans testify the high demand at the time, the economic gain that metal-producing communities must have had, and possibly different value system under which they were acquired and consumed (e.g. Radivojević 2006; Kienlin 2010) .

Dazzling metals on the one hand and glittering black-burnished ware on the other represent only some of the spectacularly crafted objects in the wider context of the $5^{\text {th }}$ millennium BC material culture in the Balkans (cf. Chapman 2011). What emerges to arise as a pattern is not only the lustrous colour spectra, which continued to expand over the course of this period with the discovery of gold, but also a specific pursuit for the ultimate expression of a completely homogenised brilliance in artefacts. In this light, the emergence and spread of metals, first copper, and in succession gold and tin bronzes may be the best illustration for such particular quest for the decisive material statement at the time. The vast number of shiny metals, pottery, stones, animal and marine materials that served the purpose of dazing the audience and / or their owners may in this context rightly be used to define the $5^{\text {th }}$ millennium BC in the Balkans as the Age of Brilliance. It may not be only supported by the fascinating material culture discovered thus far, but also by acknowledging the generations of craftsmen that persisted with this pursuit and how important the production of brilliant objects was as part of both cultural and technological identity.

From the green flames and black-and-green ores of the Vinča culture, and despite technological stagnation in the metal making recipe, the knowledge of metallurgy grew in more than half a millennium into what appears to be one of the major subsistence economies in the $5^{\text {th }}$ millennium BC Balkans, covering a wide range of colourful metals and alloys (Radivojević et al. 2013). This study does not exclude the possibility for the existence of a similar contemporary development in other regions of Eurasia; however, the characterisation of early metallurgical knowledge in those regions remains a task for future research. We attempted to demonstrate the potential material science carries in addressing the knowledge of early metallurgy in a nuanced detail, and beyond the world's earliest dated smelting event discovered in the Balkans. By looking at immanent and configurational aspects of this transformative technology, we suggest a direction for future research on the how and why of metallurgies worldwide.

\section{Acknowledgements}

This research represents part of MR's PhD research conducted at the UCL Institute of Archaeology under the supervision of Professors Th. Rehren, S. Shennan and E. Pernicka. This research was kindly 
supported by the EPSRC's Dorothy Hodgkin Postgraduate Award, Serbian Ministries of Culture, Science, and Youth and Sports, Open Society Foundations and Freeport McMoRan Copper and Gold Foundation through IAMS, the Institute for Archaeo-Metallurgical Studies in London. We continued work on this research under the larger collaborative project kindly supported by the UK AHRC, titled "The Rise of Metallurgy in Eurasia" (No. AH/J001406/1). The authors are indebted to Marcos Martinón-Torres and Michael Charlton for their most insightful comments, Julka Kuzmanović-Cvetković, Duško Šljivar, Nenad Tasić and Andrijana Pravidur for generous access to materials and Kevin Reeves and Ljiljana Radivojević for technical support. We are also grateful to Ron Jacobson, Rob Lavinsky, Leon Hupperichs and Jordi Fabre for kind permission to use mineral images. Detailed comments from three reviewers helped us to better situate our research; any remaining shortcomings are ours.

\section{Figure Captions}

Figure 1- Distribution of the Vinča culture (shaded) and the location of studied sites (adapted after Kaiser and Voytek 1983, p. 333, Figure 1; base map courtesy of M. Milinković, Faculty of Philosophy Belgrade).

Figure 2- a) Typical bead malachite from Belovode; b) Typical black-and-green copper mineral from Belovode.

Figure 3- Production evidence from the Vinča culture sites of Belovode, Vinča and Gornja Tuzla, with sample labels in bottom left corner. Free slag samples: 131, 134, 136, 79, 91, 194; slagged sherds: 30a, 30c, 31a, 31b, 182a/b; copper metal droplets 83, 190.

Figure 4- Photomicrographs of oxide and sulfide minerals studied here, under crossed polarised light (with sample labels): Belovode 34a, Belovode M10, Vinča 99, Pločnik 51, Pločnik 54m, Pločnik 57, Pločnik 71, Pločnik 209). Note the striking similarity in the presence of two phases: bright green and dark/grey across all samples. The last image is the sulfur-rich mineral Belovode 3. Note the dark section embedded in the predominantly bright green phase.

Figure 5 - Ternary plot $\mathrm{MnO}-\mathrm{ZnO}-\mathrm{CuO}$ of the results obtained for oolithic structures in all oxide minerals presented here. Note clustering of all minerals except 71 in the middle of the $\mathrm{CuO}-\mathrm{MnO}$ axis.

Figure 6 - The ternary plot of $\mathrm{SiO}_{2} / \mathrm{Al}_{2} \mathrm{O}_{3} / \mathrm{TiO}_{2}-\mathrm{CaO} / \mathrm{MgO} / \mathrm{P}_{2} \mathrm{O}_{5} / \mathrm{K}_{2} \mathrm{O}$ $\mathrm{FeO} / \mathrm{MnO} / \mathrm{ZnO} / \mathrm{NiO} / \mathrm{CoO} / \mathrm{As} 2 \mathrm{O} 3 / \mathrm{SnO}_{2} / \mathrm{Sb}_{2} \mathrm{O}_{3}$ values in slag glassy matrices in Belovode, Vinča and Gornja Tuzla samples (including data published in Radivojević et al., 2010) and the typical Vinča culture ceramics.

Figure 7- Microstructures of all slag samples (including slagged sherds), under cross polarised light, with major phases labelled: a) Belovode 30a; b) Belovode 30c; c) Belovode 31a; d) Belovode 31b; e) Belovode 131; f) Belovode 134; g) Belovode 136; h) GT 182a; i) Vinča 79; and j) Vinča 91.

Figure 8- a) Photomicrograph of Belovode M6 under plane polarised light, with major phases labelled. Note the copper metal droplets (bright yellow) embedded in the copper-based matrix / dross (grey) and the partially decomposed chalcocite (light grey); b) Photomicrograph of Pločnik 52 under plane polarised 

blocky and round) and covellite (blue).

Figure 9- The FeO-P2O5-CaO plot of slag matrices in GT 182a and GT 194, and a residual mineral phase in GT 182a, against apatite and oak and bracken ashes after Jackson and Smedley (2004, p. 39, Table 4). The only apparent compositional match is that of residual phase with apatite (mineral image copyright by Ron Jacobson, ronaldjacobson@bigpond.com). The oak and bracken ash measurements do not coincide with the slag composition at the site of Gornja Tuzla.

Figure 10- The $\mathrm{K}_{2} \mathrm{O}-\mathrm{CaO}-\mathrm{MnO}$ plot of slag matrices in Belovode production evidence against the beech ash composition from Jackson and Smedley (2004, p. 39, Table 4), including data published in Radivojević et al., 2010 (labelled with M). Distinctive clustering of data along the lime-potash (Ellipse right) and lime-manganese (Ellipse left) axes indicate fuel and ore contamination respectively. The black and green image stands for a typical representative of the kind of ores smelted in Belovode.

Figure 11- Ternary plot of $\mathrm{Al}_{2} \mathrm{O}_{3}-\mathrm{P}_{2} \mathrm{O}_{5}-\mathrm{FeO}$ values in glass matrices in Vinča 79 and 91 tested against the compositions of lazulite, turquoise and vivianite (mineral images are copyright of Rob Lavinsky, www.irocks.com). The closest match to the composition of slag matrix in Vinča 79 is vivianite, a colourful hydrated iron phosphate.

Figure 12- The $\mathrm{As}_{2} \mathrm{O}_{3}-\mathrm{P}_{2} \mathrm{O}_{5}-\mathrm{FeO}$ plot of slag matrices in GT 182a and GT 194 against mineral compositions of arthurite (copyright by Leon Hupperichs), scorodite (copyright of Rob Lavinsky, www.irocks.com) and strengite (copyright www.fabreminerals.com). GT 194 shows that this is a different type of metallurgical event, while yellow ellipse around GT 182a values indicates that the smelting charge possibly included a mixture of these minerals, or potentially phosphoroscorodite, $\left(\mathrm{Fe}(\mathrm{As}, \mathrm{P}) \mathrm{O}_{4} \cdot 2 \mathrm{H}_{2} \mathrm{O}\right)$, an intermediate phase between scorodite and strengite.

Figure 13- Green flames arising from malachite smelting experiment (Cyprus, May 2012, photo by M. Radivojević).

\section{Bibliography}

Antonović, D. (2006). Malachite finds in the Vinča culture: evidence for early copper metallurgy in Serbia. Metalurgija-Journal of Metallurgy, 12(2-3), 85-92.

Bachmann, H.-G. (1982). The Identification of Slags from Archaeological Sites (Institute of Archaeology Occasional Publication No.6). London: Institute of Archaeology.

Boivin, N. (2008). Material Cultures, Material Minds. The Impact of Things on Human Thought, Society, and Evolution. Cambridge: Cambridge University Press.

Borić, D. (2009). Absolute dating of metallurgical innovations in the Vinča culture of the Balkans. In T. L. Kienlin, \& B. W. Roberts (Eds.), Metals and Societies. Studies in honour of Barbara S. Ottaway (pp. 191-245, Universitätsforschungen zur Prähistorischen Archäologie, Vol. 169). Bonn: Verlag Dr. Rudolf Habelt GmbH.

Bourgarit, D. (2007). Chalcolithic copper smelting. In S. La Niece, D. Hook, \& P. Craddock (Eds.), Metals and Mines: Studies in Archaeometallurgy (pp. 3-14). London: Archetype Publications.

Chapman, J. (1981). Vinča Culture of South-East Europe: Studies in Chronology, Economy and Society. Oxford: British Archaeological Reports, BAR International Series 117. 
Chapman, J. (2002). Colourful Prehistories: The Problem with the Berlin and Kay Paradigm. In A. Jones, \& G. MacGregor (Eds.), Colouring the Past. The Significance of Colour in Archaeological Research (pp. 45-72). Oxford: Berg.

Chapman, J. (2006). Dark burnished ware as a sign: ethnicity, aesthetics and categories in the later Neolithic of the central Balkans. In N. Tasić, \& C. Grozdanov (Eds.), Homage to Milutin Garašanin (pp. 295-308). Belgrade: Serbian Academy of Sciences and Arts and Macedonian Academy of Sciences and Arts.

Chapman, J. (2007a). The elaboration of an aesthetic of brilliance and colour in the climax Copper Age. In F. Lang, C. Reinholdt, \& J. Weilhartner (Eds.), Stephanos Aristeios. Archäologische Forschungen zwischen Nil und Istros. Festschrift für Stefan Hiller zum 65. Geburtstag (pp. 6574). Wien: Phoibos Verlag.

Chapman, J. (2007b). Engaging with the exotic: the production of early farming communities in southeast and central Europe. In M. Spataro, \& P. Baigi (Eds.), A short walk through the Balkans. The first farmers of the Carpathian Basin and adjacent regions. Quaderno 12 (pp. 207-222). Trieste: Società per la preistoria i protostoria della regione Friuli-Venezia Giulia.

Chapman, J. (2011). Enchantment and enchainment in later Balkan prehistory: towards an aesthetic of precision and geometric order. In A. Hadjikoumis, E. Robinson, \& S. Viner (Eds.), The Dynamics of Neolithisation in Europe. Studies in Honour of Andrew Sherratt (pp. 153-176). Oxford: Oxbow Books.

Chapman, J., \& Richter, E. (2009). Geometric order and scientific principles: a view from the Mesolithic, Neolithic and Chalcolithic of central and south east Europe. In G. Bodi (Ed.), In Medias Res Praehistorie. Miscellanea in Honorem Annos LXV Peragentis Professoris Dan Monah Oblata (pp. 21-58). Iaşi: Editura Universitătii "Alexandru Ioan Cuza".

Chapman, J., \& Tylecote, R. F. (1983). Early copper in the Balkans. Proceedings of the Prehistoric Society, 49, 373-379.

Charlton, M. F., Crew, P., Rehren, T., \& Shennan, S. J. (2010). Explaining the evolution of ironmaking recipes - an example from northwest Wales. Journal of Anthropological Archaeology, 29(3), 352367, doi:10.1016/j.jaa.2010.05.001.

Chernykh, E. N. (1978). Gornoe Delo i Metallurgiya v Dreivneishei Bolgarii. Sofia: Bolgarskoi Akademii Nauk.

Čović, B. (1958). Gornja Tuzla field excavation diary. Sarajevo: National Museum of Bosnia and Herzegowina.

Čović, B. (1961). Rezultati sondiranja na preistorijskom naselju u Gornjoj Tuzli. Glasnik Zemaljskog Muzeja (Sarajevo), 15-16, 79-139.

Craddock, P. T. (2001). From hearth to furnace: evidences for the earliest metal smelting technologies in the eastern Mediterranean. Paléorient, 26(2), 151-156.

Craddock, P. T., \& Meeks, N. D. (1987). Iron in ancient copper. Archaeometry, 29(2), 187-204.

Dana, E. S., \& Ford, W. E. (1922). A Textbook of Mineralogy (with an extended treatise on crystallography and physical mineralogy) (3rd edition ed.). New York: John Wiley and Sons.

Davenport, W. G., King, M., Schlesinger, M., \& Biswas, A. K. (2002). Extractive Metallurgy of Copper (4th ed.). Oxford: Pergamon.

Elliott, J. F. (1976). Phase relationships in the pyrometallurgy of copper. Metallurgical and Materials Transactions B. Process Metallurgy and Materials Processing Science, 7(1), 17-33.

Garašanin, M. (1973). Praistorija na tlu Srbije (Prehistory in Serbia, in Serbian). Belgrade: Srpska Književna Zadruga.

Garašanin, M. (1995). Die Gradac-Stufe der Vinča-Gruppe und der Beginn des Aeneolithikums. Dacia, 38-39, 9-17.

Gell, A. (1992). The technology of enchantment and the enchantment of technology. In J. Coote, \& A. Shelton (Eds.), Anthropology, Art and Aesthetics (pp. 40-67). Oxford: Clarendon. 
Gosden, C. (2005). Comments III: Is science a foreign country? Archaeometry, 47(1), 182-185, doi:10.1111/j.1475-4754.2005.195-3.x.

Hauptmann, A. (2007). The Archaeometallurgy of Copper: Evidence from Faynan, Jordan. Berlin: Springer.

Heimann, R. B., Kreher, U., Spazier, I., \& Wetzel, G. (2001). Mineralogical And Chemical Investigations Of Bloomery Slags From Prehistoric (8th Century Bc To 4th Century Ad) Iron Production Sites In Upper And Lower Lusatia, Germany. Archaeometry, 43(2), 227-252, doi:10.1111/14754754.00016.

Henglein, M. (1962). Lötrohrprobierkunde. Fourth Edition. Sammlung Göschen Band 483. Berlin: Walter De Gruyter \& Co.

Henrich, J. (2004). Demography and cultural evolution: how adaptive cultural processes can produce maladaptive losses, the Tasmanian case. American Antiquity, 69(2), 197-214.

Hosler, D. (1994). The Sounds and Colors of Power: The Sacred Metallurgical Technology of Ancient West Mexico Cambridge, MA: The MIT Press.

Huebner, J. (1969). Stability relations of rodochrosite in the system manganese-carbon-oxygen. American Mineralogist, 54, 457-481.

Ivanov, I. (1988). Die Ausgrabungen des Gräberfeldes von Varna. In A. Fol, \& J. Lichardus (Eds.), Macht, Herrschaft und Gold: Das Gräberfeld von Varna und die Anfänge einer Neuen Europäischen Zivilisation (pp. 49-66). Saarbrücken: Moderne Galerie des Saarland-Museums.

Jackson, C. M., \& Smedley, J. W. (2004). Medieval and post-medieval glass technology: melting characteristics of some glasses melted from vegetable ash and sand mixtures. Glass Technology, 45(1), 36-42.

Janković, S. (1990). Types of copper deposits related tovolcanic environment in the Bor district, Yugoslavia. Geologische Rundschau, 79(2), 467-478.

Jones, A. (2004). Archaeometry and materiality: materials-based analysis in theory and practice. Archaeometry, 46(3), 327-338, doi:10.1111/j.1475-4754.2004.00161.x.

Jovanović, B., \& Ottaway, B. S. (1976). Copper mining and metallurgy in the Vinča group. Antiquity, 50, 104-113.

Kaiser, T., \& Voytek, B. (1983). Sedentism and economic change in the Balkan Neolithic. Journal of Anthropological Archaeology, 2(4), 323-353.

Kienlin, T. L. (2010). Traditions and Transformations: Approaches to Eneolithic (Copper Age) and Bronze Age Metalworking and Society in Eastern Central Europe and the Carphatian Basin (BAR Insternational Series 2184). Oxford: Archaeopress, British Archaeological Reports 2184.

Killick, D., \& Fenn, T. R. (2012). Archaeometallurgy: the study of preindustrial mining and metallurgy. Annual Review of Anthropology, 41, 559-575.

Kuna, M. (1981). Zur Neolithischen und Äneolithischen kupferverarbeitung im gebiet Jugoslawiens. Godišnjak Akademije BiH 17. Centar za balkanološka ispitivanja (Sarajevo), 19, 13-81.

Maldonado, B., \& Rehren, T. (2009). Early copper smelting at Itziparátzico, Mexico. Journal of Archaeological Science, 36(9), 1998-2006, doi:http://dx.doi.org/10.1016/j.jas.2009.05.019.

Martinón-Torres, M., \& Rehren, T. (2009). Post-medieval crucible production and distribution: a study of materials and materialities. Archaeometry, 51(1), 49-74, doi:10.1111/j.1475-4754.2007.00380.x.

Martinón-Torres, M., Rojas, R. V., Cooper, J., \& Rehren, T. (2007). Metals, microanalysis and meaning: a study of metal objects excavated from the indigenous cemetery of El Chorro de Maíta, Cuba. Journal of Archaeological Science, 34(2), 194-204.

Milojčić, V. (1949). Chronologie der Jüngeren Steinzeit Mittel- und Südosteuropas. Berlin: Mann.

Muhly, J. D. (1989). Çayönü Tepeşi and the beginnings of metallurgy in the Old World. In A. Hauptmann, E. Pernicka, \& G. A. Wagner (Eds.), Old World Archaeometallurgy, Der Anschnitt, Beiheft 7 (pp. 1-13, Der Anschnitt, Vol. 7). Bochum: Deutsches Bergbau-Museum. 
Murciego, A., Álvarez-Ayuso, E., Pellitero, E., Rodríguez, M. A., García-Sánchez, A., Tamayo, A., et al. (2011). Study of arsenopyrite weathering products in mine wastes from abandoned tungsten and tin exploitations. Journal of Hazardous Materials, 186(1), 590-601.

Murillo-Barroso, M., \& Montero-Ruíz, I. (2012). Copper ornaments in the Iberian Chalcolithic: technology versus social demand. Journal of Mediterranean Archaeology, 25(1), 53-73.

Ottaway, B. S. (2001). Innovation, production and specialisation in early prehistoric copper metallurgy. European Journal of Archaeology, 4(1), 87-112.

Pernicka, E., Begemann, F., \& Schmitt-Strecker, S. (1993). Eneolithic and Early Bronze Age copper artefacts from the Balkans and their relation to Serbian copper ores. Prähistorische Zeitschrift, $68,1-54$.

Pernicka, E., Begemann, F., Schmitt-Strecker, S., Todorova, H., \& Kuleff, I. (1997). Prehistoric copper in Bulgaria. Its composition and provenance. Eurasia Antiqua, 3, 41-180.

Powell, A., Shennan, S., \& Thomas, M. G. (2009). Late pleistocene demography and the appearance of modern human behavior. Science, 324(5932), 1298-1301, doi:DOI 10.1126/science.1170165.

Quitta, H., \& Kol, G. (1969). Radiocarbondaten zum Neolithikum und zur frühen Bronzezeit Südosteuropas und der Sowietunion. Zeitschrift Fur Archaologie, 3, 223-255.

Radivojević, M. (2006). A contribution to the typology and distribution of hammer axes of Pločnik type in southeast Europe (in Serbian). Journal of Serbian Archaeological Society, 22, 211-224.

Radivojević, M. (2007). Evidence for early copper smelting in Belovode, a Vinča culture settlement in Eastern Serbia. UCL Institute of Archaeology, London.

Radivojević, M. (2012). On the Origins of Metallurgy in Europe: Metal Production in the Vinča Culture. UCL Institute of Archaeology, London.

Radivojević, M. (forthcoming). Inventing metallurgy in western Eurasia: a look through the microscope lens. Cambridge Archaeological Journal, 25(1).

Radivojević, M., \& Kuzmanović-Cvetković, J. (2014). Copper minerals and archaeometallurgical materials from the Vinča culture sites of Belovode and Pločnik: overview of the evidence and new data. Starinar, 64, 7-30.

Radivojević, M., Rehren, T., Kuzmanović-Cvetković, J., Jovanović, M., \& Northover, J. P. (2013). Tainted ores and the rise of tin bronze metallurgy, c. 6500 years ago. Antiquity, 87(338), 10301045

Radivojević, M., Rehren, T., Pernicka, E., Šljivar, D., Brauns, M., \& Borić, D. (2010). On the origins of extractive metallurgy: new evidence from Europe. Journal of Archaeological Science, 37(11), 2775-2787.

Rapp, G. (2009). Archaeomineralogy (2nd ed., Natural Science in Archaeology). Berlin, Heidelberg: Springer-Verlag.

Rehder, J. E. (1994). Blowpipes versus bellows in ancient metallurgy. Journal of Field Archaeology, 21(3), 345-350.

Rehren, T. (1997). Die Rolle des Kohlenstoffs in der Prähistorischen Metallurgie. Stahl Und Eisen, 117(9), 87-92.

Rehren, T., Charlton, M., Chirikure, S., Humphris, J., Ige, A., \& Veldhuijzen, H. A. (2007). Decisions set in slag-the human factor in African iron smelting. In S. La Niece, D. Hook, \& P. Craddock (Eds.), Metals and Mines: Studies in Archaeometallurgy (pp. 211-218). London: Archetype Publications.

Renfrew, C. (1969). The autonomy of the south-east European Copper Age. Proceedings of the Prehistoric Society, 35, 12-47.

Roberts, B., \& Thornton, C. P. (Eds.). (2014). Archaeometallurgy in Global Perspective. Methods and Syntheses. New York: Springer.

Roberts, B. W., Thornton, C. P., \& Pigott, V. C. (2009). Development of metallurgy in Eurasia. Antiquity, 83, 1012-1022. 
Roux, V. (2008). Evolutionary trajectories of technological traits and cultural transmission. In M. Stark, B. J. Bowser, \& L. Horne (Eds.), Cultural Transmission and Material Culture (pp. 82-104). Tucson: The University of Arizona Press.

Roux, V. (2010). Technological innovation and developmental trajectories: social factors as evolutionary forces In M. J. O'Brien, \& S. J. Shennan (Eds.), Innovation in Cultural Systems. Contributions from Evolutionary Anthropology (pp. 217-234). Cambridge, MA: The MIT Press.

Ryndina, N. (2009). The potential of metallography in investigations of early objects made of copper and copper-based alloys. Historical Metallurgy, 43(1), 1-18.

Ryndina, N., Indenbaum, G., \& Kolosova, V. (1999). Copper production from polymetallic sulphide ores in the northeastern Balkan Eneolithic culture. Journal of Archaeological Science, 26(8), 10591068.

Schmidt, P. R. (2009). Tropes, Materiality, and Ritual Embodiment of African Iron Smelting Furnaces as Human Figures. Journal of Archaeological Method and Theory, 16(3), 262-282, doi:10.2307/40346017.

Schubert, F. (1965). Zu den südosteuropäischen Kupferäxten. Germania, 43(2), 274-295.

Shennan, S. (2001). Demography and cultural innovation: a model and its implications for the emergence of modern human culture. Cambridge Archaeological Journal, 11(1), 5-16.

Shennan, S., \& Steele, J. (1999). Cultural learning in hominids: a behavioural ecological approach. In H. O. Box, \& K. R. Gibson (Eds.), Mammalian Social Learning: Comparative and Ecological Perspectives (pp. 367-388). Cambridge: Cambridge University Press.

Sillar, B., \& Tite, M. S. (2000). The challenge of 'technological choices' for materials science approaches in archaeology. Archaeometry, 42(1), 2-20.

Sillitoe, R. H. (1983). Enargite-bearing massive sulfide deposits high in porphyry copper systems. Economic Geology, 78, 348-352.

Simpson, G. G. (1963). Historical Science. In C. C. J. Albritton (Ed.), The Fabric of Geology (pp. 24-48). Stanford: Freeman, Cooper and Co.

Šljivar, D., Jacanović, D., \& Kuzmanović-Cvetković, J. (2006). New contributions regarding the copper metallurgy in the Vinča culture. In N. Tasić, \& C. Grozdanov (Eds.), Homage to Milutin Garašanin (pp. 251-266). Belgrade: Serbian Academy of Sciences and Arts and Macedonian Academy of Sciences and Arts.

Šljivar, D., \& Kuzmanović-Cvetković, J. (2009). Pločnik, archaeology and conservation. Diana (Belgrade), 13, 56-61.

Smith, C. S. (1981). On art, invention and technology. In S. C. Smith (Ed.), A Search for Structure (pp. 325-331). Cambridge (MA): The MIT Press.

Srejović, D. (1972). Europe's First Monumental Sculpture: New Discoveries at Lepenski Vir. London: Thames and Hudson.

Tasić, N. N. (2003-2009). Vinča-Belo Brdo field excavation documentation Belgrade: Project Archives, Centre for Digital Archaeology, Faculty of Philosophy.

Thornton, C. P. (2009). The Emergence of complex metallurgy on the Iranian Plateau: escaping the Levantine Paradigm. Journal of World Prehistory, 22(3), 301-327, doi:DOI 10.1007/s10963-0099019-1.

Tite, M. S., Kilikoglou, V., \& Veknis, G. (2001). Strength, toughness and thermal shock resistance of ancient ceramics, and their influence on technological choice. Archaeometry, 45, 301-324.

Todorova, H., \& Vajsov, I. (1993). Novo-Kamennata Epokha v Bulgariya. Sofia: Nauka i Izkustvo.

Tylecote, R. F., \& Boydell, P. J. (1978). Experiments on copper smelting. In B. Rothenberg, R. F. Tylecote, \& P. J. Boydell (Eds.), Chalcolithic Copper Smelting (pp. 27-49). London: Institute for Archaeometallurgical Studies. 
Tylecote, R. F., Ghaznavi, H. A., \& Boydell, P. J. (1977). Partitioning of trace elements between the ores, fluxes, slags and metal during the smelting of copper. Journal of Archaeological Science, 4(4), 305-333.

Vértes, L. (1965). The depot of silex blades from Boldogkőváralja. Acta Archaeologica Hungarica, 17, 128-136.

Vincenti, W. G. (2000). Real-world variation-selection in the evolution of technological form: historical examples. In J. Ziman (Ed.), Technological Innovation as an Evolutionary Process (pp. 174-189). Cambridge: Cambridge University Press.

Vogel, J. C., \& Waterbolk, H. T. (1963). Groningen radiocarbon dates IV. Radiocarbon, 5(1), 163-202.

Washburn, D., \& Crowe, D. (Eds.). (2004). Symmetry Comes of Age. Seattle: University of Washington Press.

Wolverton, S., \& Lyman, R. L. (2000). Immanence and configuration in analogical reasoning. North American Archaeologist, 21(3), 233-247. 


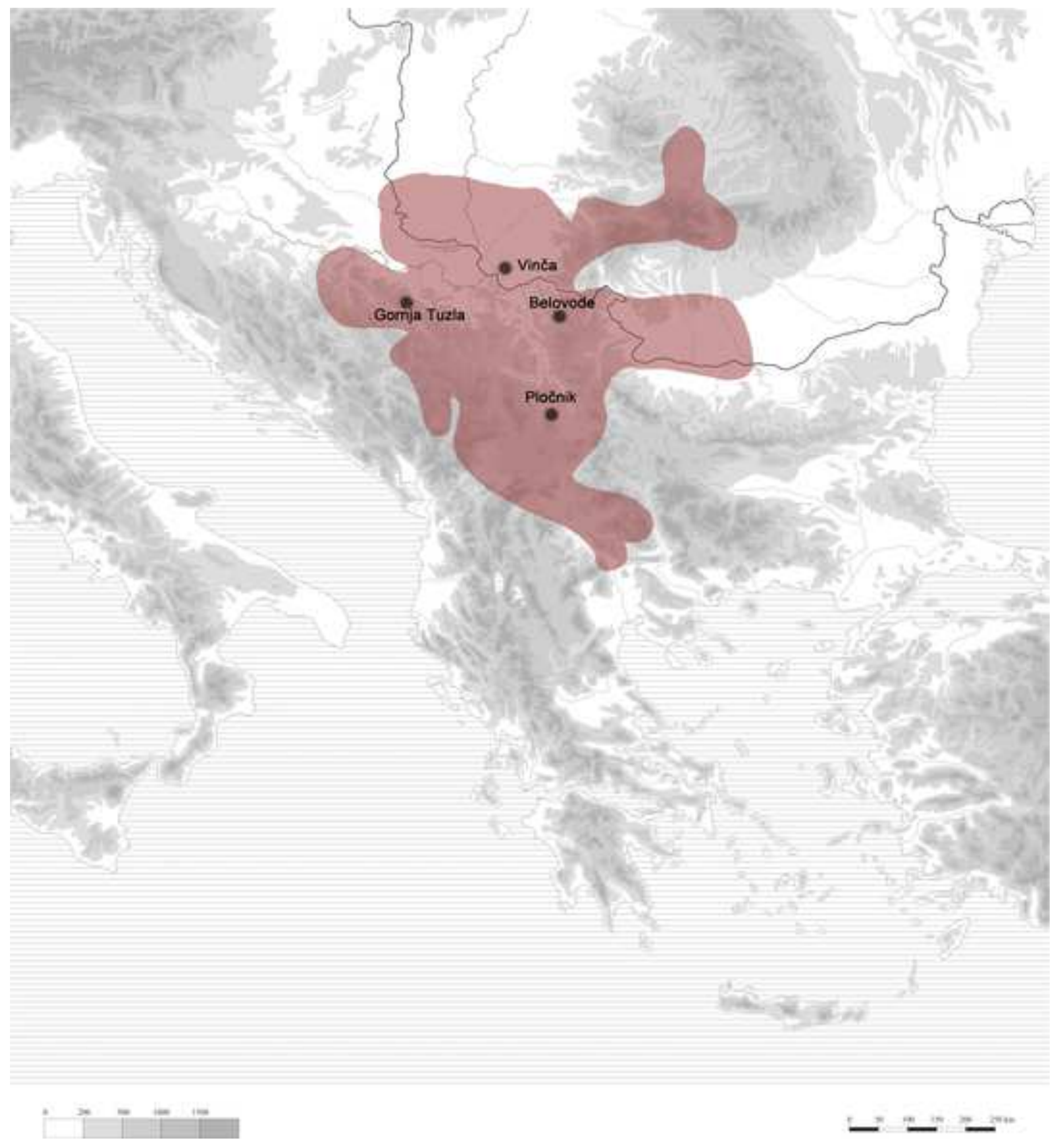


Click here to download high resolution image

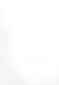

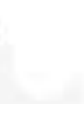

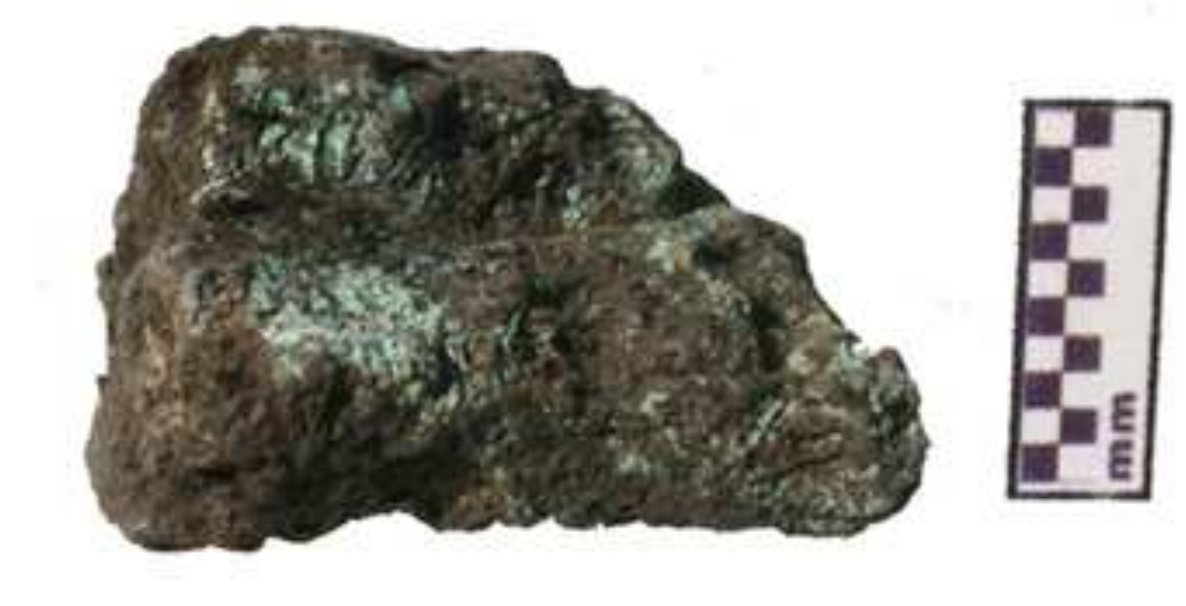
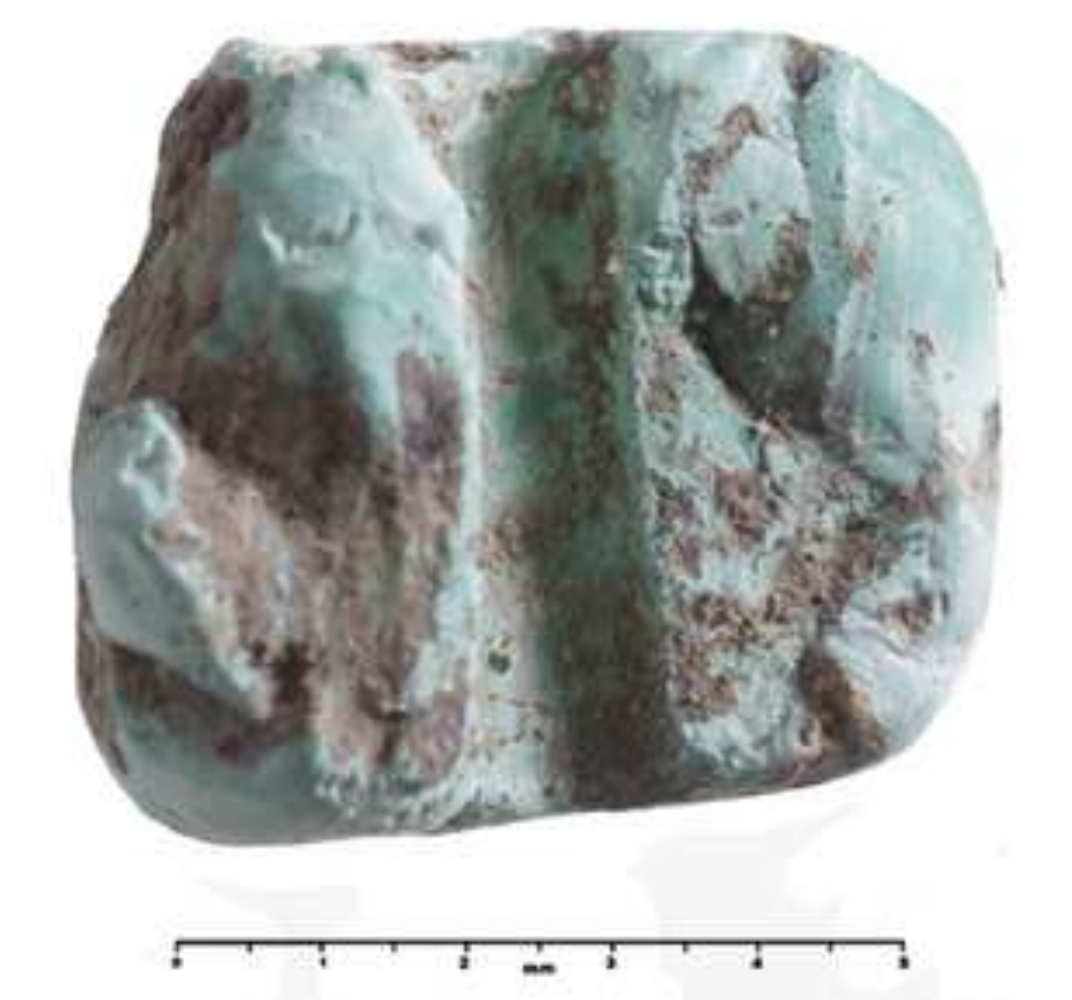

m, 
Figure
Click here to download high resolution image

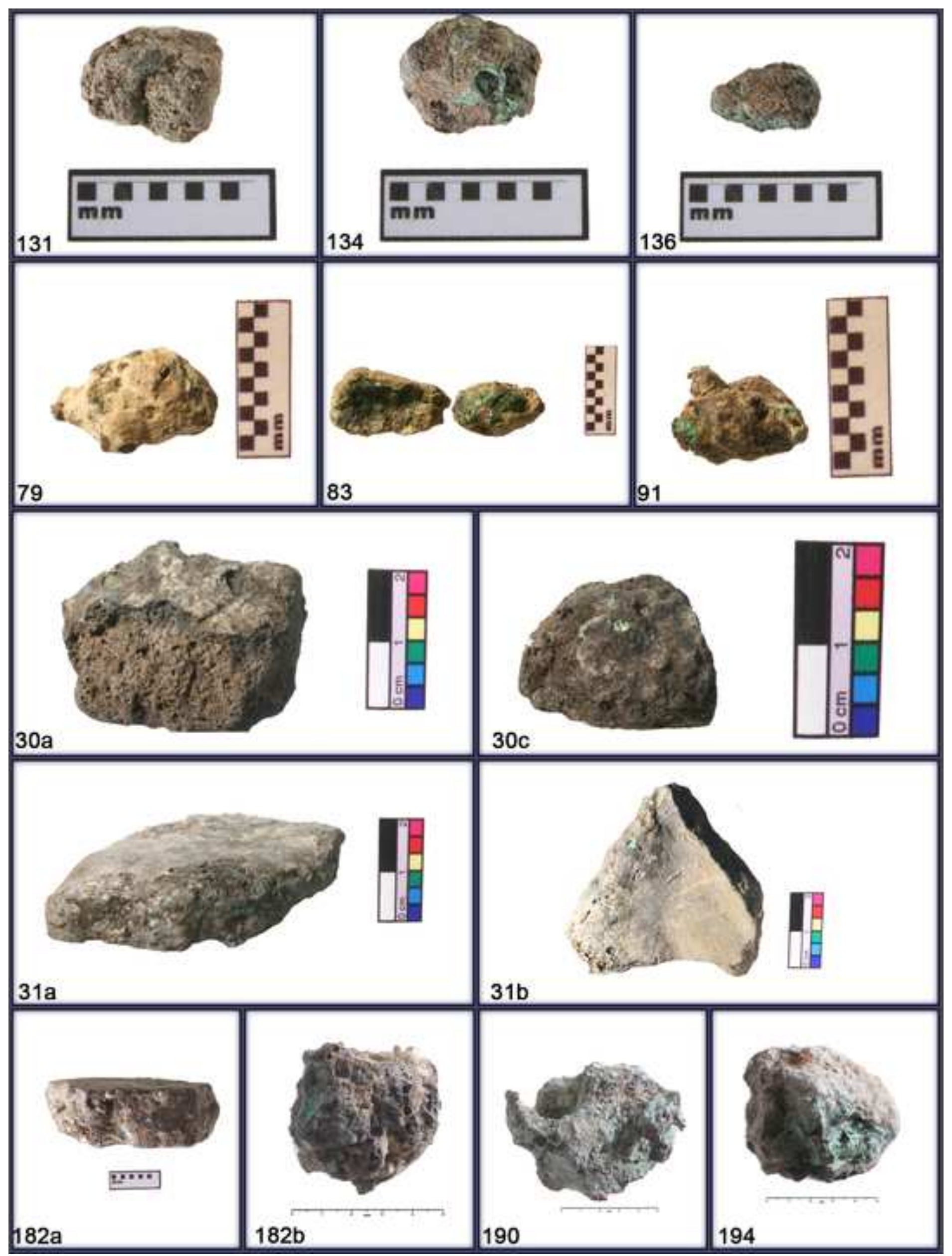



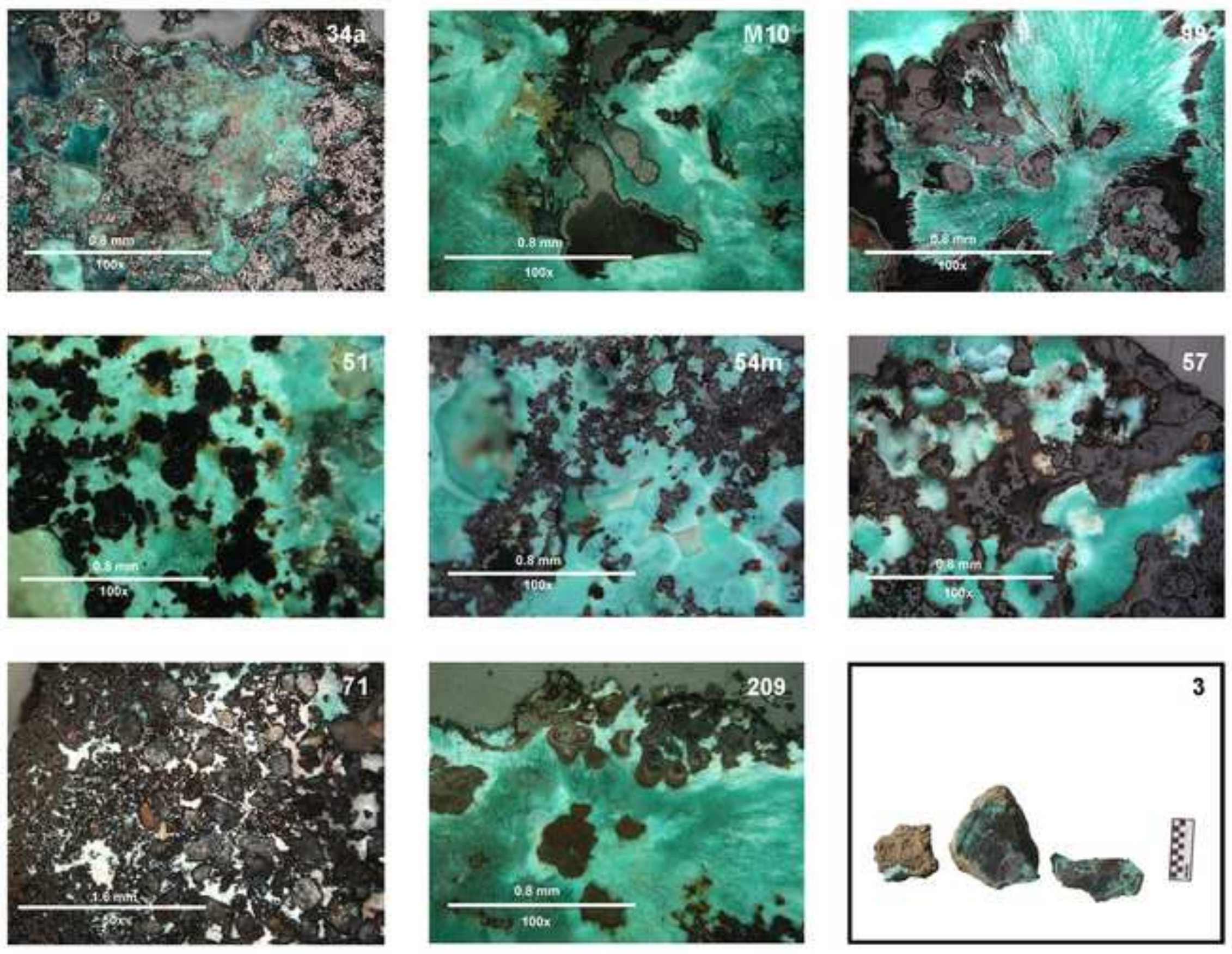


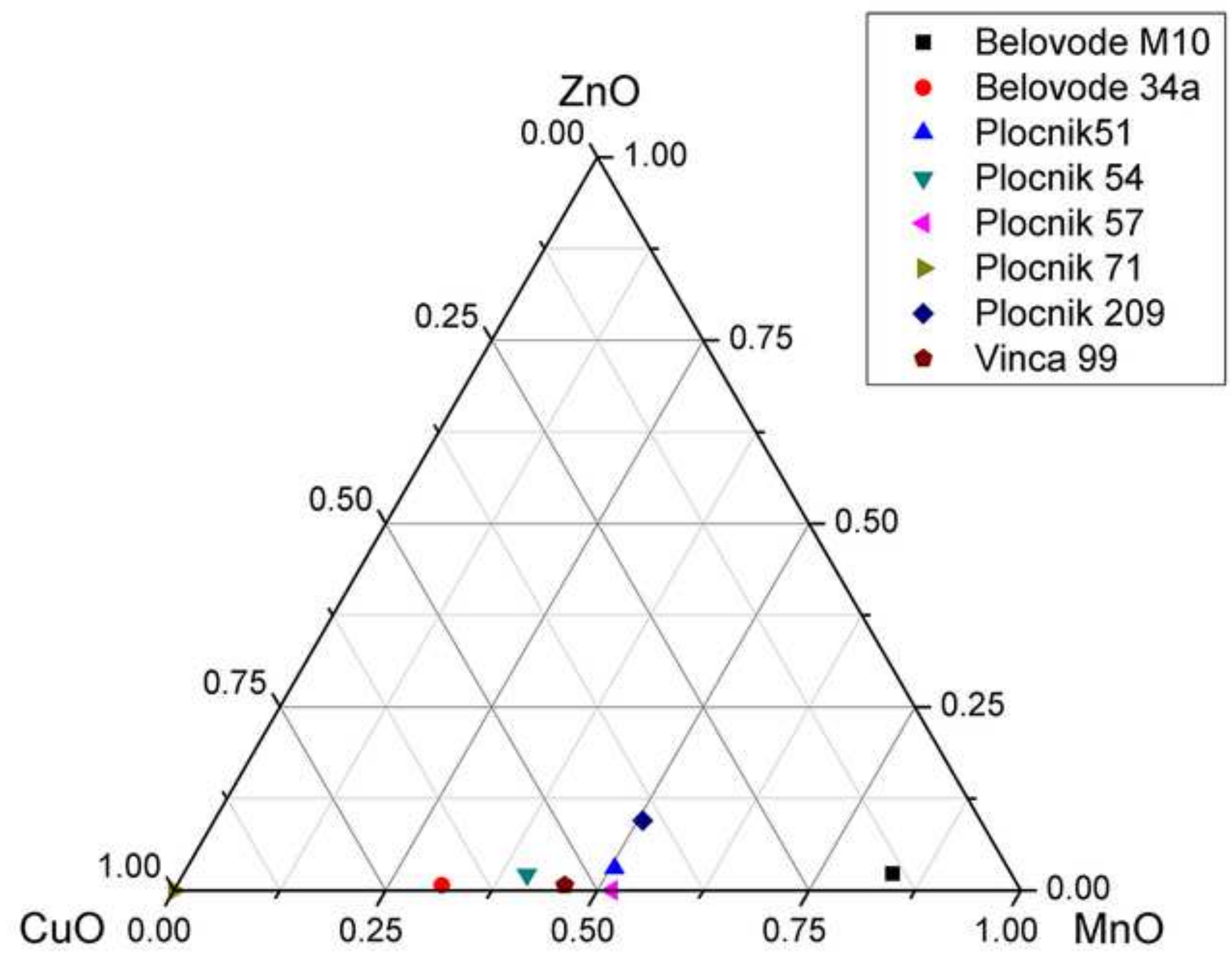




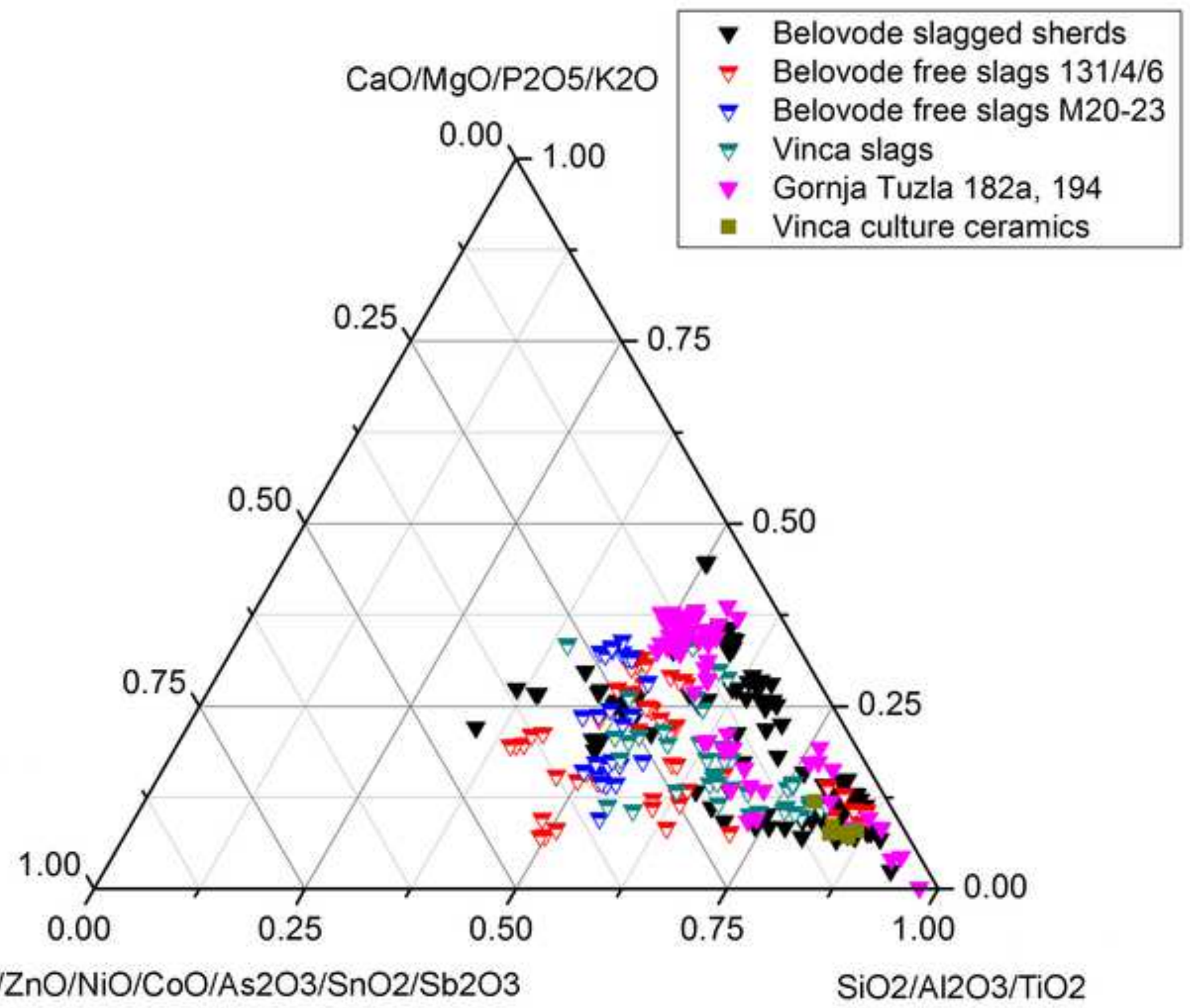

$\mathrm{FeO} / \mathrm{MnO} / \mathrm{ZnO} / \mathrm{NiO} / \mathrm{CoO} / \mathrm{As} 2 \mathrm{O} 3 / \mathrm{SnO} 2 / \mathrm{Sb} 2 \mathrm{O} 3$ 

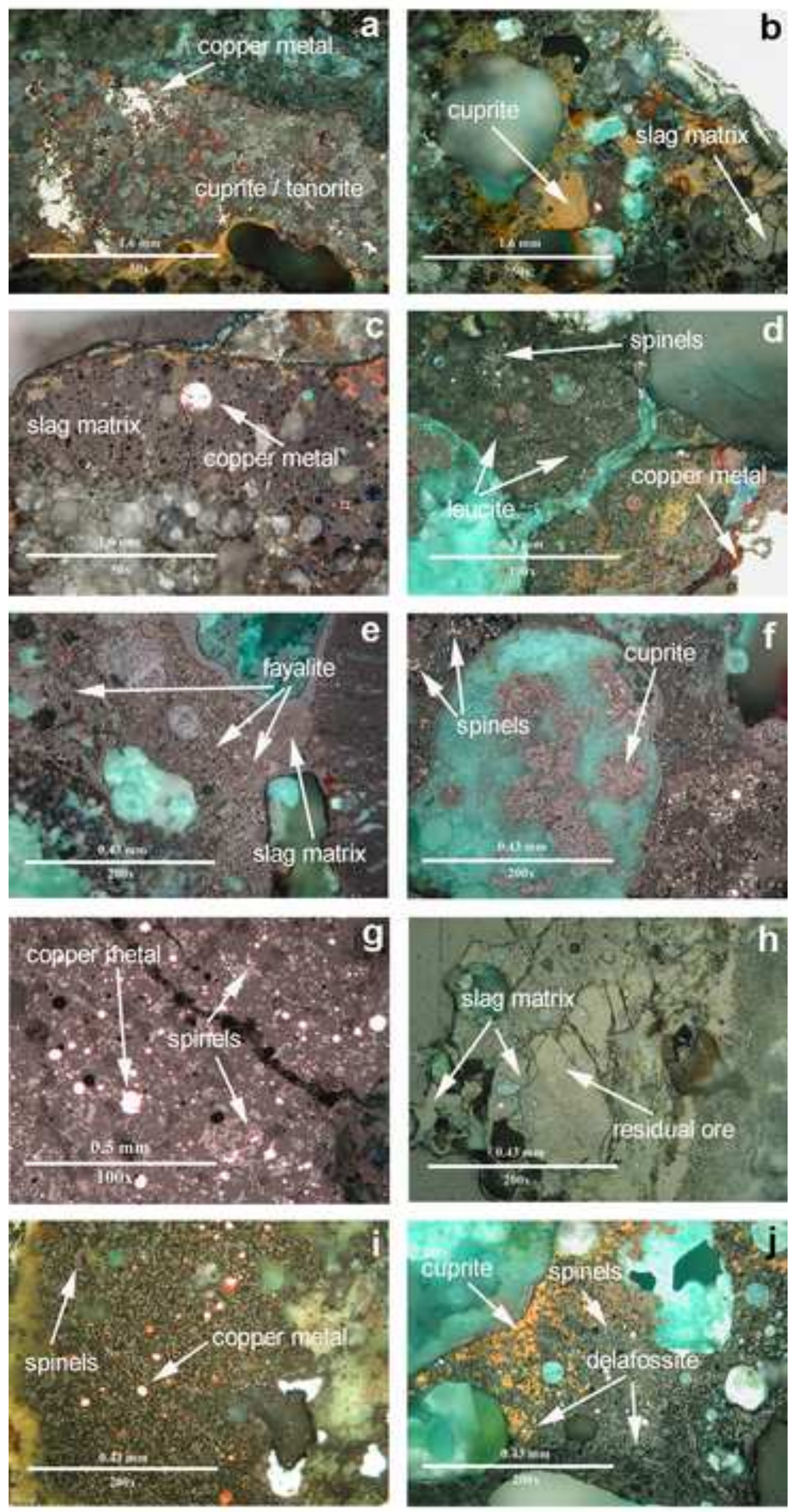
Click here to download high resolution image
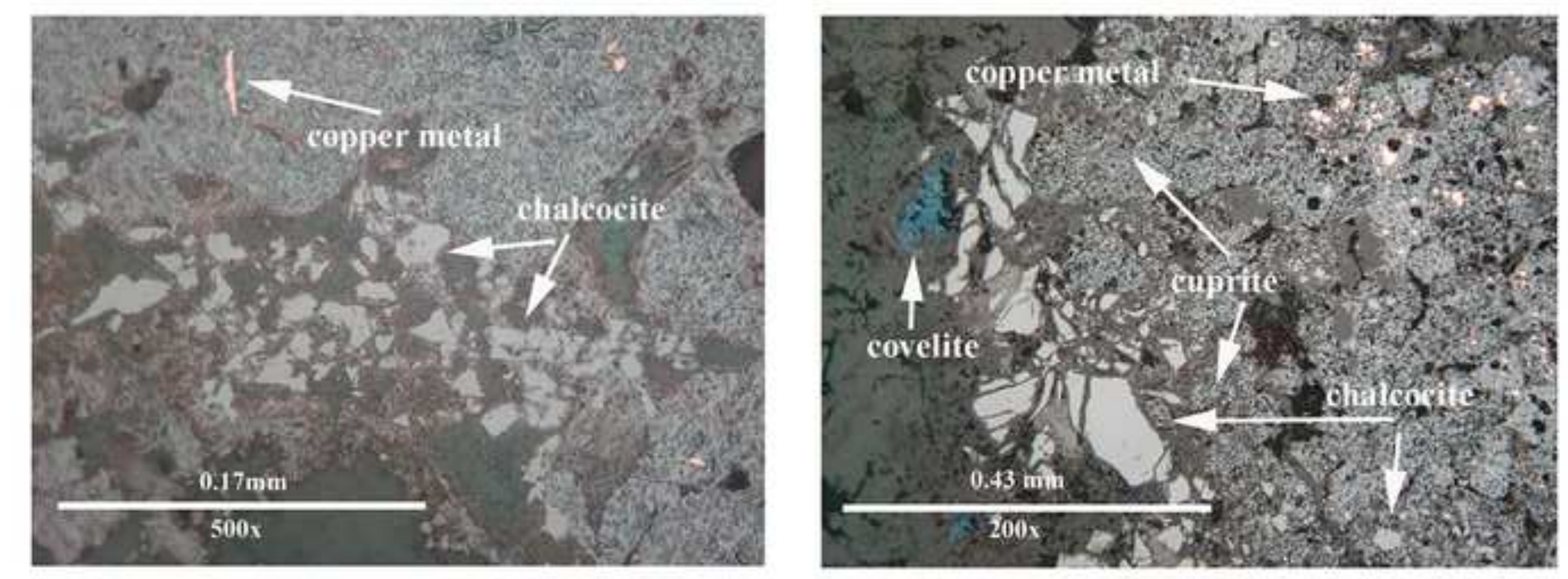


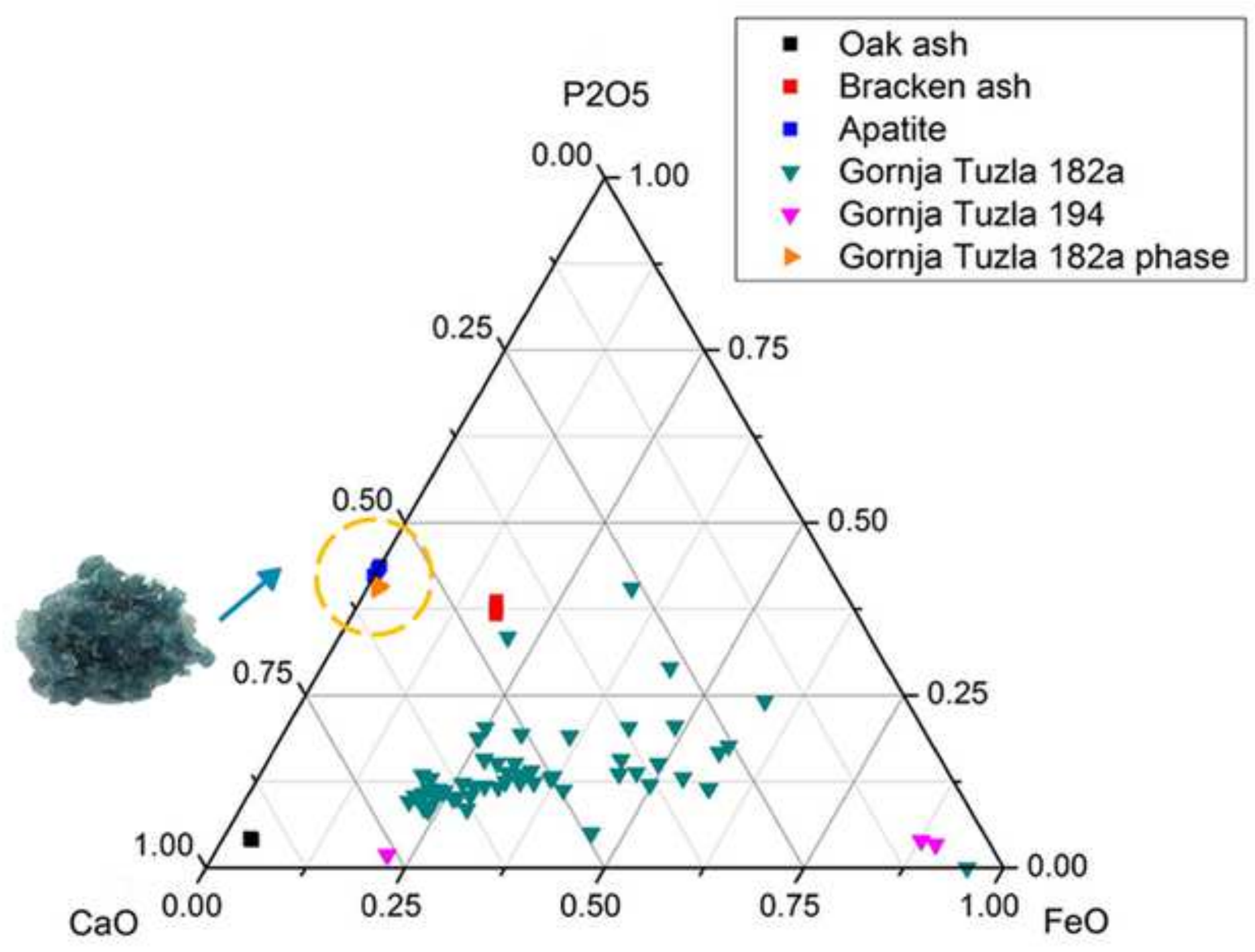




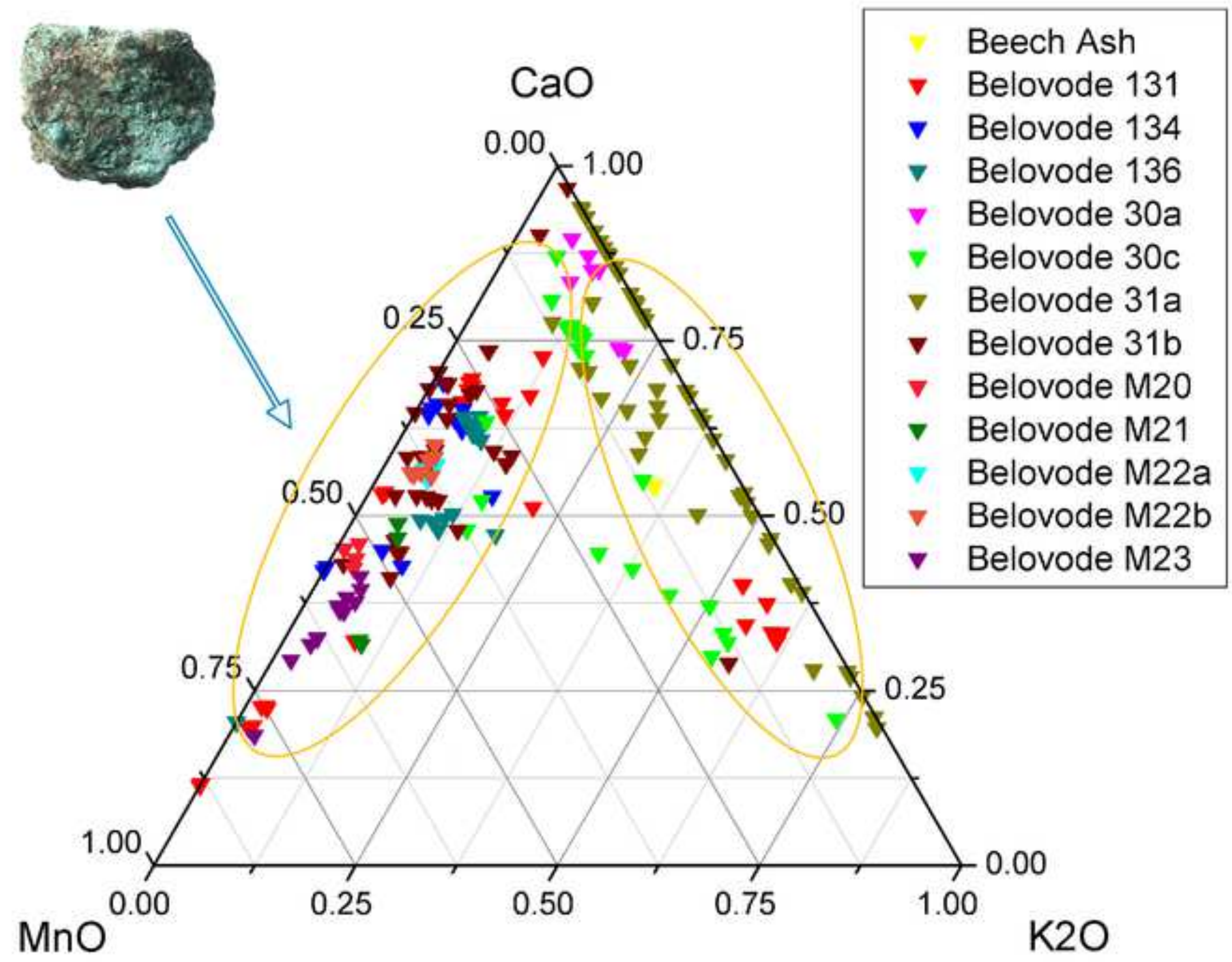




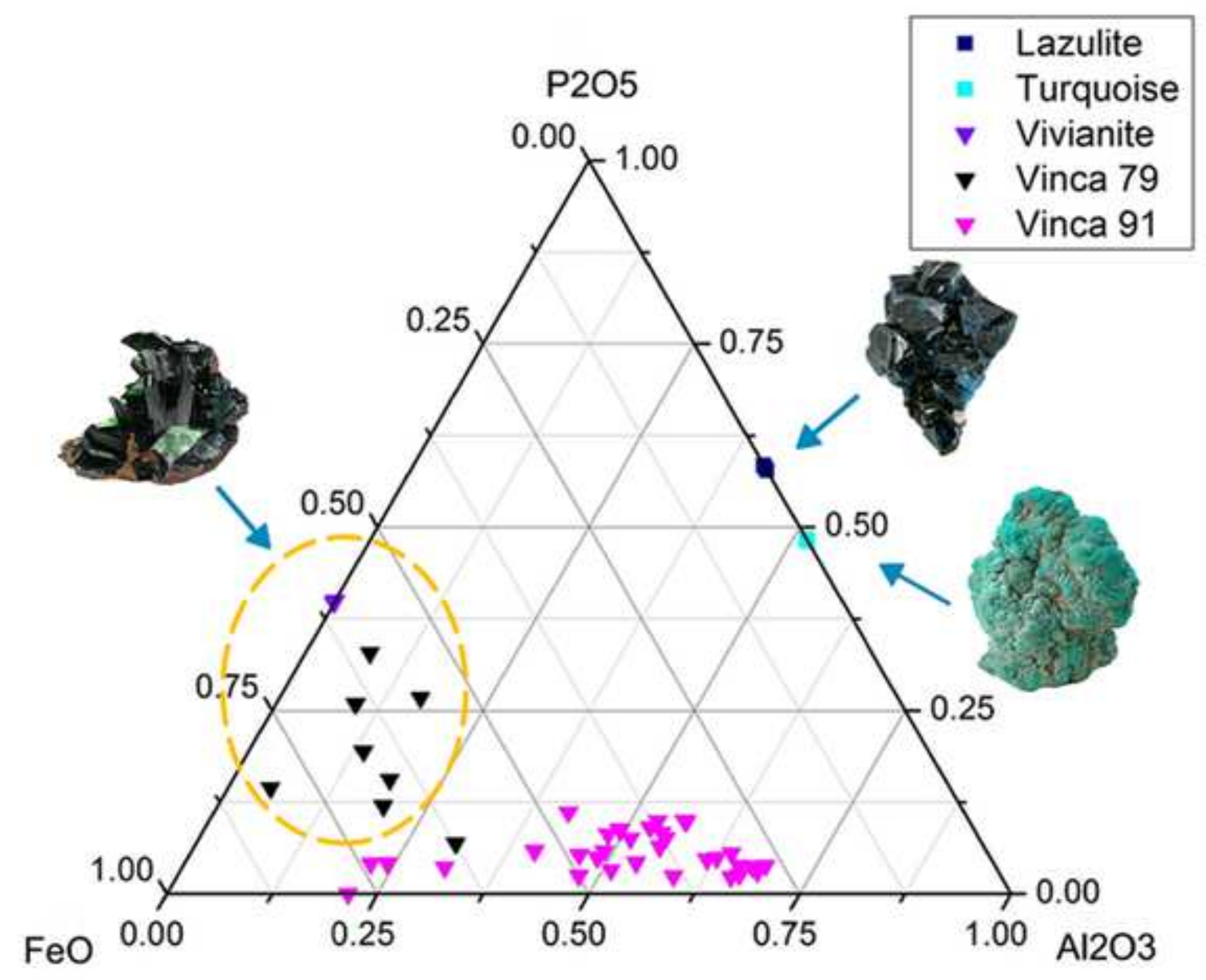




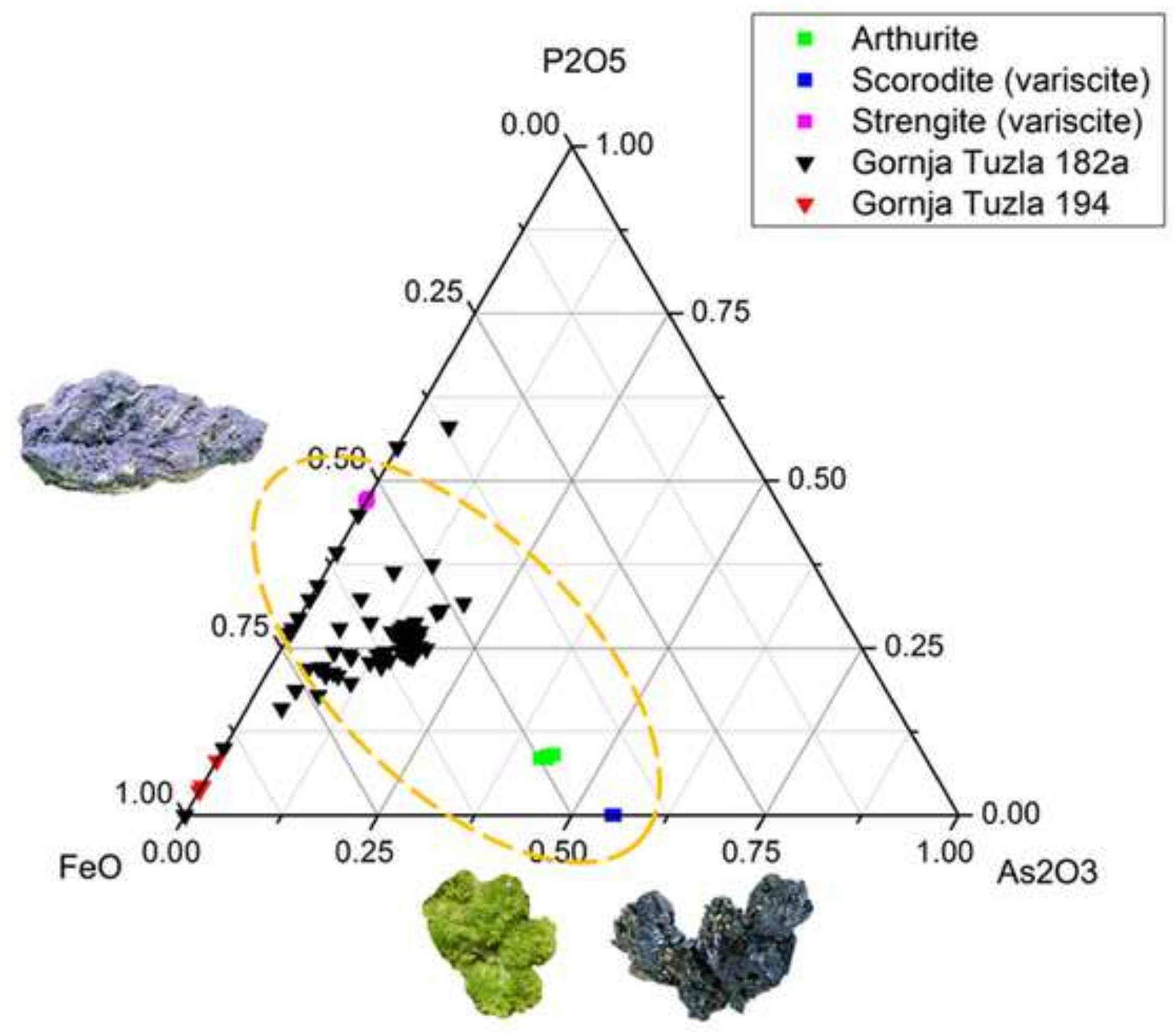



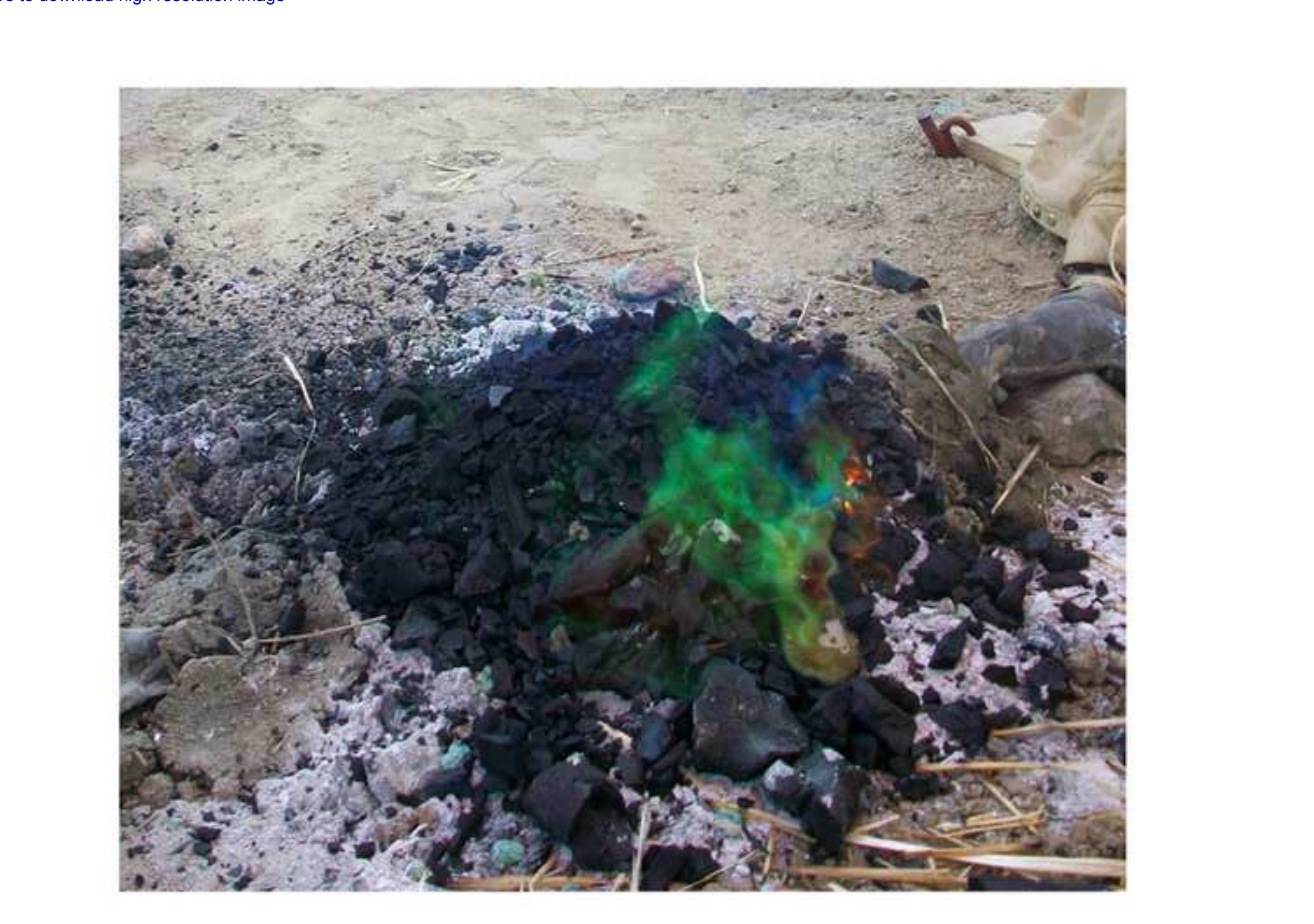

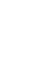




\begin{tabular}{|c|c|c|c|c|c|c|}
\hline No. & Analytical No. & Type of Material & Field label & Field context & $\begin{array}{c}\text { Relative } \\
\text { chronology }\end{array}$ & EPMA \\
\hline 1 & Belovode 3 & Copper mineral & Trench 13, spit 14 & Household & Vinča B1 & \\
\hline $2-3$ & Belovode 30a, 30c & Slagged ceramic sherd & Trench 3 , spit 5 ; waste pit & Waste pit & Gradac Phase & $\mathrm{X}(30 \mathrm{a})$ \\
\hline $4-5$ & Belovode 31a, 31b & Slagged ceramic sherd & Trench 3, spit 6; waste pit & Waste pit & Gradac Phase & $\mathrm{XX}$ \\
\hline 6 & Belovode 33b & Copper mineral & Trench 14 , spit 15 & Household & Vinča B1 & \\
\hline 7 & Belovode 34a & Copper minerals & Trench 14, spit 3 & Household, in an amphora & Gradac Phase & \\
\hline 8 & Belovode 131 & Copper slag & Trench 3, spit 6 & Waste pit & Gradac Phase & $X$ \\
\hline 9 & Belovode 134 & Copper slag & Trench 3 , spit 7 & Waste pit & Gradac Phase & $\mathrm{X}$ \\
\hline 10 & Belovode 136 & Copper slag & Trench 3 , spit 5 & Waste pit & Gradac Phase & \\
\hline 12 & Belovode M10 & Copper mineral & Trench 3, spit 19 & Household & Vinča B1 & \\
\hline 13 & Vinča 79 & Copper slag & Edm 95 & Household, near a fireplace & Vinča D1/D2 & $\mathrm{X}$ \\
\hline 14 & Vinča 83 & Copper metal droplet & Edm 1259 & Household & Vinča D1/D2 & $\mathrm{X}$ \\
\hline 15 & Vinča 91 & Copper slag & Edm 485 & Within a (ritual?) feature & Vinča D1/D2 & $\mathrm{X}$ \\
\hline 16 & Vinča 99 & Copper mineral & Edm 276 & Household, near a fireplace & Vinča D1/D2 & \\
\hline 17 & Pločnik 51 & Copper mineral & Trench 19 , spit 23 & Household & Vinča A & \\
\hline 18 & Pločnik 52 & Copper metal droplet & Trench 14 , spit 10 & Household & Vinča B1 & $\mathrm{X}$ \\
\hline 19 & Pločnik 54m & Copper mineral & Trench 16 , spit 19 & Household & Vinča B1 & \\
\hline 20 & Pločnik 57 & Copper mineral & Trench 19 , spit 13 & Household & Vinča B1 & \\
\hline 22 & Pločnik 72m & Copper mineral & Trench 20 , spit 3 & Workshop & Gradac Phase & \\
\hline 23 & Pločnik 209 & Copper mineral & Trench 22, spit 15 & Workshop & Vinča B1 & \\
\hline 24 & Gornja Tuzla 182a/b & Slagged ceramic sherd & Trench II/1, stratum II & Household, charred wood & Vinča D & $\mathrm{X}$ \\
\hline 25 & Gornja Tuzla 190 & Copper metal droplet & Trench II/1, stratum II & Household, near a fireplace & Vinča D & $\mathrm{X}$ \\
\hline 26 & $\begin{array}{l}\text { Gornja Tuzla } 194 \\
\end{array}$ & Slag? & Trench II/1, stratum II & Household, near a fireplace & Vinča D & \\
\hline 27 & Belovode M20 & Copper slag & Trench 3, spit 2 & Waste pit & Gradac Phase & $\overline{\mathrm{X}}$ \\
\hline 28 & Belovode M21 & Copper slag & Trench 3 , spit 4 & Waste pit & Gradac Phase & $\mathrm{X}$ \\
\hline $29-30$ & Belovode M22 $(a, b)$ & Copper slag & Trench 3 , spit 5 & Waste pit & Gradac Phase & $\mathrm{XX}$ \\
\hline 31 & Belovode M23 & Copper slag & Trench 3, spit 7 & Waste pit & Gradac Phase & $\mathrm{X}$ \\
\hline
\end{tabular}

Table 1- Sampled materials description, context and relative chronology. All samples were analysed with optical microscope (OM) and scanning electron microscope with energy dispersive spectrometer (SEM-EDS), and only a selected number with Electron Probe Micro Analyser (EPMA). The Vinča culture is dated between c. 5400 and 4600 BC. Vinča A lasted from c. 5400/5300 BC until c. 5200 BC; Vinča B from c. 5200 BC to c. 5000/4950 BC, which us the beginning of the Gradac Phase, which lasted for c. 50-100 years in central parts of the Vinča culture, and longer elsewhere. Vinča C is dated from c. $4900-4850 / 4800$ BC, and Vinča D from c. 4800 BC until c. 4650/4600 BC. 


\begin{tabular}{|c|c|c|c|c|c|c|c|c|c|c|c|c|c|c|c|c|c|c|}
\hline & $\mathrm{Na} 2 \mathrm{O}$ & $\mathrm{MgO}$ & $\mathrm{A} 2 \mathrm{O} 3$ & $\mathrm{SiO} 2$ & $\mathrm{P} 205$ & SO3 & К2O & CaO & TiO2 & $\mathrm{MnO}$ & $\mathrm{FeO}$ & $\mathrm{CoO}$ & $\mathrm{NiO}$ & $\mathrm{CuO}$ & $\mathrm{ZnO}$ & $\mathrm{As} 2 \mathrm{O} 3$ & $\mathrm{SnO} 2$ & $\mathrm{Sb} 2 \mathrm{O} 3$ \\
\hline & $\mathrm{w} \%$ & $\mathrm{w} \%$ & $\mathrm{w} \%$ & $\mathrm{w} \%$ & $\mathrm{w} \%$ & $\mathrm{w} \%$ & $\mathrm{w} \%$ & $\mathrm{w} \%$ & $\mathrm{w} \%$ & $\mathrm{w} \%$ & $\mathrm{w} \%$ & $\mathrm{w} \%$ & $\mathrm{w} \%$ & $\mathrm{w} \%$ & $\mathrm{w} \%$ & $\mathrm{w} \%$ & $\mathrm{w} \%$ & $\mathrm{w} \%$ \\
\hline Belovode 30a slag matrix & bdl & 2.9 & 8.9 & 38.5 & 1.4 & bdl & 3.9 & 23.0 & 0.6 & 1.1 & 6.4 & bdl & bdl & 13.2 & 0.1 & bdl & bdl & bdl \\
\hline stdev $30 a$ & 0.0 & 1.3 & 2.4 & 2.1 & 1.5 & 0.0 & 2.2 & 4.3 & 0.3 & 0.7 & 2.3 & 0.0 & 0.0 & 5.3 & 0.3 & 0.0 & 0.0 & 0.0 \\
\hline Belovode 30c slag matrix & bdl & 2.5 & 9.8 & 40.1 & 1.7 & bdl & 3.6 & 12.5 & 0.5 & 2.0 & 5.6 & 0.1 & bdl & 21.2 & 0.4 & bdl & bdl & bdl \\
\hline stdev $30 c$ & 0.0 & 1.0 & 2.8 & 4.2 & 1.6 & 0.0 & 1.3 & 7.9 & 0.3 & 1.0 & 2.5 & 0.2 & 0.0 & 7.3 & 0.3 & 0.0 & 0.0 & 0.0 \\
\hline Belovode 31a slag matrix & 1.8 & 1.7 & 16.3 & 50.1 & 1.4 & bdl & 3.0 & 7.9 & 0.7 & 0.4 & 7.5 & bdl & bdl & 9.0 & 0.1 & bdl & bdl & bdl \\
\hline stdev $31 a$ & 1.4 & 1.1 & 5.6 & 6.2 & 1.9 & 0.0 & 1.5 & 4.7 & 0.5 & 0.8 & 3.3 & 0.1 & 0.0 & 8.2 & 0.2 & 0.0 & 0.0 & 0.0 \\
\hline Belovode 31b slag matrix & 0.8 & 1.6 & 6.0 & 40.4 & 3.9 & bdl & 1.8 & 15.0 & 0.3 & 8.4 & 12.7 & 0.5 & bdl & 7.3 & 1.4 & bdl & bdl & Bdl \\
\hline stdev $31 \mathrm{~b}$ & 0.7 & 0.8 & 2.6 & 7.4 & 1.6 & 0.0 & 1.2 & 6.5 & 0.3 & 5.2 & 4.4 & 0.4 & 0.0 & 14.2 & 0.9 & 0.0 & 0.0 & 0.0 \\
\hline Belovode 131 slag matrix & 0.1 & 1.7 & 8.9 & 46.8 & 4.3 & bdl & 1.7 & 8.6 & 0.4 & 7.1 & 17.0 & 0.2 & bdl & 2.6 & 0.6 & bdl & bdl & bdl \\
\hline stdev 131 & 0.4 & 1.6 & 2.9 & 9.0 & 1.6 & 0.0 & 1.2 & 6.4 & 0.2 & 6.8 & 9.2 & 0.2 & 0.0 & 3.9 & 0.7 & 0.0 & 0.0 & 0.0 \\
\hline Belovode 134 slag matrix & 0.9 & 1.9 & 7.3 & 41.6 & 3.5 & 0.3 & 0.9 & 13.6 & 0.2 & 7.4 & 10.1 & 0.3 & bdl & 10.9 & 1.1 & bdl & bdl & bdl \\
\hline stdev134 & 0.7 & 1.0 & 1.4 & 4.7 & 0.8 & 0.5 & 0.8 & 7.7 & 0.2 & 2.7 & 4.7 & 0.3 & 0.0 & 12.0 & 0.5 & 0.0 & 0.0 & 0.0 \\
\hline Belovode 136 slag matrix & 0.5 & 1.6 & 6.9 & 36.4 & 3.2 & bdl & 2.5 & 16.8 & 0.2 & 9.8 & 12.0 & 0.7 & bdl & 7.5 & 1.8 & bdl & bdl & bdl \\
\hline stdev136 & 0.4 & 0.4 & 0.6 & 4.3 & 0.6 & 0.0 & 1.0 & 6.2 & 0.2 & 0.4 & 7.6 & 0.3 & 0.1 & 8.0 & 0.4 & 0.0 & 0.0 & 0.0 \\
\hline Vinča 79 slag matrix & bdl & 0.9 & 4.6 & 38.3 & 7.3 & bdl & 5.7 & 5.7 & 0.1 & 1.5 & 26.0 & 0.1 & bdl & 9.9 & 0.1 & bdl & bdl & bdl \\
\hline stdev 79 & 0.0 & 0.2 & 2.5 & 4.5 & 3.1 & 0.0 & 4.1 & 3.1 & 0.2 & 0.3 & 3.0 & 0.2 & 0.0 & 3.7 & 0.2 & 0.0 & 0.0 & 0.0 \\
\hline Vinča 91 slag matrix & 0.2 & 4.2 & 11.5 & 47.2 & 1.5 & bdl & 3.9 & 5.6 & 0.5 & 2.7 & 11.9 & 0.1 & bdl & 9.6 & 1.0 & bdl & bdl & bdl \\
\hline stdev 91 & 0.4 & 1.7 & 2.8 & 3.9 & 0.5 & 0.0 & 3.3 & 5.5 & 0.4 & 2.6 & 3.4 & 0.2 & 0.0 & 4.6 & 0.4 & 0.0 & 0.0 & 0.0 \\
\hline GT 182a slag matrix & 1.1 & 4.7 & 11.6 & 41.9 & 3.3 & bdl & 2.4 & 14.4 & 0.6 & 0.1 & 7.9 & bdl & 0.1 & 10.1 & bdl & 1.5 & 0.1 & 0.2 \\
\hline st.dev & 1.2 & 3.0 & 4.2 & 8.5 & 1.1 & 0.1 & 1.8 & 6.7 & 0.3 & 0.2 & 2.9 & 0.1 & 0.1 & 8.4 & 0.1 & 0.9 & 0.3 & 0.4 \\
\hline GT 194 slag matrix & 0.2 & 8.0 & 15.5 & 48.2 & 0.6 & bdl & 2.8 & 6.7 & 0.5 & bdl & 12.6 & bdl & bdl & 4.8 & bdl & bdl & bdl & bdl \\
\hline st.dev & 0.3 & 6.9 & 3.5 & 7.8 & 0.1 & 0.0 & 1.2 & 9.5 & 0.5 & 0.0 & 6.8 & 0.0 & 0.0 & 3.6 & 0.0 & 0.0 & 0.0 & 0.0 \\
\hline average Vinča ceramic & 1.5 & 1.9 & 15.8 & 64.0 & 0.7 & 0.0 & 3.5 & 2.7 & 0.8 & 0.0 & 9.1 & 0.0 & 0.0 & 0.0 & 0.0 & 0.0 & 0.0 & $\mathbf{0 . 0}$ \\
\hline stdev & 1.1 & 0.8 & 0.6 & 2.8 & 0.6 & 0.0 & 0.6 & 1.4 & 0.1 & 0.0 & 1.7 & 0.0 & 0.0 & 0.0 & 0.0 & 0.0 & 0.0 & 0.0 \\
\hline
\end{tabular}

Table 2: SEM-EDS compositional data for glassy matrices in the metal production evidence from the sites of Belovode, Vinča and Gornja Tuzla, normalised to $100 \%$. Additional lines at the bottom include the typical Vinča ceramic composition, based on measurements from all three sites. All values are given as averages and standard deviation of three to sixty-three analyses of each sample, corrected with factors based on certified reference materials analysis and minimal reliability threshold established for measurements acquired by the analytical setup for each of the reported elements (published in supplementary materials). Bdl=below detection limit. 


\begin{tabular}{|c|c|c|c|c|c|c|c|c|c|c|}
\hline Sample & $\begin{array}{c}\text { Copper } \\
\text { metal }\end{array}$ & $\begin{array}{l}\text { Copper } \\
\text { oxides }\end{array}$ & Delafossite & Spinels & Leucite & Pyroxene & Olivine & Wüstite & Iscorite & $\begin{array}{c}\text { Iron in Cu } \\
(\mathrm{ppm})\end{array}$ \\
\hline Belovode 30a & & & & & & & & & & bdl \\
\hline Belovode 30c & & & & & & & & & & bdl \\
\hline Belovode 31a & & & & & & & & & & bdl \\
\hline Belovode 31b & & & & & & & & & & bdl \\
\hline Belovode 131 & & & & & & & & & & 36000 \\
\hline Belovode 134 & & & & & & & & & & 10200 \\
\hline Belovode 136 & & & & & & & & & & bdl \\
\hline $\begin{array}{l}\text { Vinča } 79 \\
\end{array}$ & & & & & & & & & & bdl \\
\hline $\begin{array}{ll}\text { Vinča } 83 \\
\end{array}$ & & & & & & & & & & 150 \\
\hline Vinča 91 & & & & & & & & & & 2400 \\
\hline GT 182a & & & & & & & & & & bdl \\
\hline GT 190 & & & & & & & & & & 3000 \\
\hline GT 194 & & & & & & & & & & bdl \\
\hline
\end{tabular}

Table 3: Newly-formed phases in the Vinča culture production evidence, with iron shown in a separate column in ppm values). Bdl- below detection limit. SEM-EDS was used for phase determination, while iron content in copper prills is analysed with EPMA. Fe readings in Belovode 134 (in italic) are not taken into consideration since the diameter of the analysed metal prills was smaller than the effective analytical volume excited by the electron beam.

\begin{tabular}{c|cccccccccccc} 
& $\mathrm{MgO}$ & $\mathrm{Al} 2 \mathrm{O} 3$ & $\mathrm{SiO} 2$ & $\mathrm{P} 2 \mathrm{O} 5$ & $\mathrm{CaO}$ & $\mathrm{TiO} 2$ & $\mathrm{MnO}$ & $\mathrm{FeO}$ & $\mathrm{CoO}$ & $\mathrm{NiO}$ & $\mathrm{CuO}$ & $\mathrm{ZnO}$ \\
& $\mathrm{wt} \%$ & $\mathrm{wt} \%$ & $\mathrm{wt} \%$ & $\mathrm{wt} \%$ & $\mathrm{wt} \%$ & $\mathrm{wt} \%$ & $\mathrm{wt} \%$ & $\mathrm{wt} \%$ & $\mathrm{wt} \%$ & wt\% & wt\% & wt\% \\
\hline Belovode 31b & 0.9 & 3.3 & 1.5 & 0.3 & 0.6 & 0.4 & 6.5 & 81.4 & 2.1 & 0.2 & 0.8 & 2.0 \\
Belovode 131 & $\mathrm{Bdl}$ & 2.5 & 0.9 & 0.2 & $\mathrm{bdl}$ & $\mathrm{bdl}$ & 1.0 & 92.6 & 0.7 & $\mathrm{bdl}$ & 1.1 & 0.9 \\
Belovode 134 & 3.2 & 7.0 & 0.5 & $\mathrm{bdl}$ & 0.2 & 0.1 & 11.9 & 67.6 & 3.1 & 0.3 & 3.0 & 3.1 \\
Belovode 136 & 1.5 & 3.5 & 0.2 & $\mathrm{bdl}$ & 0.4 & 0.1 & 13.0 & 69.8 & 3.1 & 0.4 & 4.4 & 3.5 \\
Vinča 79 & 1.2 & 0.2 & 0.5 & $\mathrm{bdl}$ & 0.2 & $\mathrm{bdl}$ & 7.9 & 85.1 & 2.1 & 0.1 & 2.4 & 0.2 \\
Vinča 91 & 2.9 & 5.6 & 1.7 & $\mathrm{bdl}$ & 0.3 & 0.3 & 4.5 & 75.1 & 1.2 & 0.4 & 4.8 & 3.1 \\
GT 190 & 2.8 & 0.3 & 2.2 & 0.7 & 1.1 & $\mathrm{bdl}$ & 0.1 & 75.1 & 3.2 & 0.4 & 14.0 & 0.1 \\
\hline
\end{tabular}

Table 4: SEM-EDS compositional analyses of iron spinels in the Vinča culture production evidence from Belovode, Vinča and Gornja Tuzla, normalised to $100 \%$. All values are given as averages and corrected with factors based on certified reference materials analysis and minimal reliability threshold established for measurements acquired by the analytical software for each of the reported elements (published in supplementary materials). Bdl=below detection limit. 


\begin{tabular}{|c|c|c|c|c|c|c|c|c|c|c|}
\hline & $\begin{array}{c}\mathrm{S} \\
\mathrm{ppm}\end{array}$ & $\begin{array}{l}\mathrm{Mn} \\
\mathrm{ppm}\end{array}$ & $\begin{array}{c}\mathrm{Fe} \\
\mathrm{ppm}\end{array}$ & $\begin{array}{l}\text { Co } \\
\mathrm{ppm}\end{array}$ & $\begin{array}{c}\mathrm{Ni} \\
\mathrm{ppm}\end{array}$ & $\begin{array}{l}\mathrm{Zn} \\
\mathrm{ppm}\end{array}$ & $\begin{array}{l}\text { As } \\
\text { ppm }\end{array}$ & $\begin{array}{c}\mathrm{Sb} \\
\mathrm{ppm}\end{array}$ & $\begin{array}{l}\mathrm{Au} \\
\mathrm{ppm}\end{array}$ & $\begin{array}{l}\text { Analytical } \\
\text { totals (av.) }\end{array}$ \\
\hline Belovode 30a & $b d l$ & $b d l$ & 10 & $b d l$ & 70 & $b d l$ & 20 & $b d l$ & 20 & 99.8 \\
\hline Belovode 31a & $B d l$ & $b d l$ & $b d l$ & $b d l$ & 60 & $b d l$ & 10 & $b d l$ & 90 & 99.9 \\
\hline Belovode $31 \mathrm{~b}$ & 20 & $b d l$ & 20 & $b d l$ & 70 & $b d l$ & $b d l$ & $b d l$ & 110 & 99.2 \\
\hline Belovode 131 & 150 & 8150 & 36100 & 10560 & 960 & 2970 & 220 & 235 & 150 & 99.2 \\
\hline Belovode 134 & 80 & 3000 & 10200 & 500 & 45 & 60 & 20 & $b d l$ & 210 & 99.0 \\
\hline Vinča 79 & $b d l$ & $b d l$ & $b d l$ & $b d l$ & 50 & $b d l$ & 30 & $b d l$ & 15 & 99.0 \\
\hline Vinča 83 & 10 & 40 & 150 & $b d l$ & 40 & 50 & 10 & $b d l$ & 360 & 99.1 \\
\hline Vinča 91 & 90 & $b d l$ & 2400 & 114 & 260 & $b d l$ & 30 & $b d l$ & 150 & 99.7 \\
\hline Gornja Tuzla 182a & 80 & $b d l$ & $b d l$ & $b d l$ & 145 & 30 & 1250 & 20 & 30 & 99.0 \\
\hline Gornja Tuzla 190 & 740 & $b d l$ & 3020 & 370 & 140 & 950 & 20 & $b d l$ & 35 & 100.3 \\
\hline
\end{tabular}

Table 5: EPMA compositional data of copper metal prills from production evidence from the sites of Belovode, Vinča and Gornja Tuzla, normalised to $100 \%$. Reliable values established at $\geq 10 \mathrm{ppm}$. $\mathrm{Mn}$ and Fe readings in Belovode 134 (here italic) are not taken into consideration since the diameter of the analysed metal prills was smaller than the effective analytical volume excited by the electron beam; thus we suspect that we received readings from the immediate analytical surrounding, including the glass matrix. All data are corrected for values obtained from the reference material (pure copper standard, published in supplementary materials). Analytical totals represent average values of total of all measurements in each sample (bdl=below detection limit). 


\section{Supplementary Materials}

\section{Methodology \\ 1.1 Sampling and Preparation}

The sampling strategy initially involved selecting materials on the basis of their visual appearance, and their response to a magnet (slag and slagged materials). The research collection was appropriately catalogued, measured and photographed prior to sample preparation and analysis. This stage was followed by careful designing of analytical strategy for each sample (Table 1).

Samples selected for microstructural and compositional study were cut to size (where necessary) using an abrasive saw, washed with water, dried and mounted in an epoxy resin. These were then ground using abrasive disks (1200 and 2400 grit) and polished using diamond pastes $(1 \mu \mathrm{m}$ and $1 / 4 \mu \mathrm{m})$. Mounted polished blocks were washed in an ultrasonic bath and rinsed with ethanol between each grinding and polishing stage. As polished blocks they were suitable for the initial analytical stage, reflected light microscopy (OM), with photomicrographs taken on the Leica and Olympus microscopes at 25x, 50x, 100x, 200x, 500x and 1000x. In the following analytical stage, compositional analysis, samples were carbon-coated to be suitable for examination under the Scanning Electron Microscope with Energy Dispersive Spectrometry (SEM-EDS) and Electron Probe Micro Analyser (EPMA) respectively. The EPMA was used only for the samples which contained a distinctive copper metal phase. The EPMA analyses were conducted by Kevin Reeves, technician at the Wolfson Archaeological Science Laboratories, UCL Institute of Archaeology, London.

\subsection{Microstructural Analysis}

Analyses of microstructures were conducted primarily with optical microscopy $(\mathrm{OM})$, while SEM-EDS played only a minor role in distinguishing phases in the 
studied samples. Optical microscopy is an established method in archaeometallurgy for studying optical properties of geologically-formed minerals (e.g. oolithic formations) or artificially generated phases (e.g. crystals in the slag matrix). These properties were used to identify which minerals/phases were present in the sample and inform on their generation. OM analyses were conducted on all polished blocks, using two different microscopes (Table 1).

\begin{tabular}{|c|c|c|}
\hline Instruments & Aim of Analysis & Analytical Parameters \\
\hline $\begin{array}{l}\text { Reflected Polarized Light } \\
\text { Microscopy } \\
\text { (Leica DMLM and } \\
\text { Olympus BX60) }\end{array}$ & $\begin{array}{l}\text { Phase identification and visual } \\
\text { characterisation of microstructure }\end{array}$ & $\begin{array}{l}\text { Plane polarized light and crossed } \\
\text { polarized light were applied to } \\
\text { examine phases in samples, their } \\
\text { colour, homogeneity, porosity and } \\
\text { inclusions (shape, size and } \\
\text { uniformity). Cross-polarized light was } \\
\text { also applied for internal reflection and } \\
\text { identifying the composition of phases } \\
\text { present. The microscope was } \\
\text { equipped with a Nikon digital camera, } \\
\text { with highest magnification of } 1000 x \text {. }\end{array}$ \\
\hline $\begin{array}{l}\text { SEM-EDS } \\
\text { Scanning Electron } \\
\text { Microscopy with Energy } \\
\text { Dispersive Spectrometry } \\
\text { (Philips XL30ESEM, } \\
\text { Superprobe JEOL- JXA- } \\
8600 \text {, } \\
\text { Hitachi S-3400N, and } \\
\text { Belgrade-based JEOL } \\
\text { JSM-6610LV for copper } \\
\text { mineral ornaments from } \\
\text { Lepenski Vir) }\end{array}$ & $\begin{array}{l}\text { 1. Phase identification in } \\
\text { samples using electron } \\
\text { images and area/point } \\
\text { analyses } \\
\text { 2. Quantitative compositional } \\
\text { analyses of observed phases } \\
\text { 3. Observation of the } \\
\text { relationships between } \\
\text { phases on the basis of their } \\
\text { atomic number contrast }\end{array}$ & $\begin{array}{l}\text { Backscattered electron (BSE) } \\
\text { imaging used. All materials analysed } \\
\text { on Philips and JXA- } 8600 \text {. } \\
\text { Environmental Secondary Electron } \\
\text { Detector in VP-SEM (vacuum) mode } \\
\text { was applied for analyses of malachite } \\
\text { beads (Hitachi, JSM-6610LV). The } \\
\text { accelerating voltage was } 20 \mathrm{kV} \text {, with } \\
\text { average dead-time of } 35-40 \% \text { and } \\
\text { working distance of } 10 \mathrm{~mm} \text {. The } \\
\text { analytical volume of the beam } \\
\text { depended on the density of analysed } \\
\text { material, for metallic phases its } \\
\text { diameter was c. } 2 \mu \text { m, and for lighter } \\
\text { materials (slag, ceramic), nearer } 5 \\
\mu \text { m. All data are presented as } \\
\text { normalized with stoichiometrically } \\
\text { added oxygen, if not otherwise stated. } \\
\text { The iron content is presented as FeO, } \\
\text { which here stands for total iron (both } \\
\text { valencies). }\end{array}$ \\
\hline $\begin{array}{l}\text { EPMA } \\
\text { Electron Probe Micro } \\
\text { Analysis (Superprobe } \\
\text { JEOL-JXA-8100) }\end{array}$ & $\begin{array}{l}\text { Compositional analysis of copper } \\
\text { metal phases in all samples } \\
\text { (down to trace element level) }\end{array}$ & $\begin{array}{l}\text { All samples analysed at an } \\
\text { accelerating voltage of } 20 \mathrm{kV} \text {, beam } \\
\text { current } 50 \mathrm{nA} \text {, with average dead- } \\
\text { time of } 35-40 \% \text { and working distance } \\
\text { of } 10 \mathrm{~mm} \text {. The following elements } \\
\text { were checked for: } \mathrm{Se}, \mathrm{Zn}, \mathrm{Cu}, \mathrm{Fe}, \mathrm{As} \text {, } \\
\mathrm{Ag}, \mathrm{Cl}, \mathrm{Te}, \mathrm{S}, \mathrm{Au}, \mathrm{Sn}, \mathrm{Bi}, \mathrm{Co}, \mathrm{Sb}, \mathrm{Ni} \text {, } \\
\mathrm{Mn}, \mathrm{Pb} \text {. All data presented as wt } \% \\
\text { and ppm, with the trusted values for } \\
\text { the latter established at } \geq 10 \mathrm{ppm} \text {. }\end{array}$ \\
\hline
\end{tabular}

Table 1: Analytical instruments used in this study, aim of analysis and relevant analytical parameters. 


\subsection{Compositional Analysis}

\subsubsection{SEM-EDS}

SEM-EDS was used to chemically characterise the phases present in the samples and assess their relation to the given analytical context (Table 1). It was applied for analysing all types of materials mounted in polished blocks. All polished blocks were carbon-coated, and analysed under the same conditions: accelerating voltage of EDS was $20 \mathrm{kV}$, with an average dead-time of $35-40 \%$ and working distance of $10 \mathrm{~mm}$. The analytical volume of the beam varied depending on the density of the analysed material. For metallic phases, its diameter is in the range of 2 $\mu \mathrm{m}$, while for lighter phases/materials such as slag or ceramic, it is nearer $5 \mu \mathrm{m}$. BSE imaging was used as default for faster recognition of samples' components. The data processing was controlled by INCA X-cite software, which processes, displays and stores the images and spectra acquired by the analyser. A cobalt standard is used to calibrate the EDS analyser, and is scanned every 25-30 minutes to guard against analytical drift. The acquired spectra from all analysed samples were carefully checked for every detected element, and particularly visually searched for the following elements: $\mathrm{P}, \mathrm{S}, \mathrm{Mn}, \mathrm{Fe}, \mathrm{Co}, \mathrm{Ni}, \mathrm{Cu}, \mathrm{Zn}, \mathrm{As}, \mathrm{Sn}, \mathrm{Sb}$, and $\mathrm{Pb}$. The detailed examination of spectra led to establishing the minimal reliability threshold for measurements acquired by the INCA software for each of the checked elements. These values were used as guidelines in the following round of data digestion, which scrutinised measurements below the set minimum for each of these compounds (Table 2), expressed as oxides with oxygen determined by stoichiometry.

\begin{tabular}{|c|c|c|c|c|c|c|c|c|c|c|c|c|}
\hline & $\begin{array}{l}\mathrm{P} 2 \mathrm{O} 5 \\
\mathrm{wt} \%\end{array}$ & $\begin{array}{l}\text { SO3 } \\
\text { wt } \%\end{array}$ & $\begin{array}{l}\mathrm{MnO} \\
\mathrm{wt} \%\end{array}$ & $\begin{array}{l}\mathrm{FeO} \\
\mathrm{wt} \%\end{array}$ & $\begin{array}{l}\mathrm{CoO} \\
\mathrm{wt} \%\end{array}$ & $\begin{array}{l}\mathrm{NiO} \\
\mathrm{wt} \%\end{array}$ & $\begin{array}{l}\mathrm{CuO} \\
\mathrm{wt} \%\end{array}$ & $\begin{array}{l}\mathrm{ZnO} \\
\mathrm{wt} \%\end{array}$ & $\begin{array}{c}\text { As } 203 \\
\text { wt } \%\end{array}$ & $\begin{array}{l}\mathrm{SnO} 2 \\
\mathrm{wt} \%\end{array}$ & $\begin{array}{l}\mathrm{SbO} \\
\mathrm{wt} \%\end{array}$ & $\begin{array}{l}\mathrm{PbO} \\
\mathrm{wt} \%\end{array}$ \\
\hline ceramics and slag & 0.4 & 0.5 & 0.31 & 0.34 & 0.4 & 0.3 & 0.37 & 0.39 & 0.49 & 0.8 & 0.72 & I \\
\hline oxidised metal & 0.61 & 0.36 & 0.37 & 0.58 & 0.39 & 0.42 & ok & 0.3 & 0.38 & I & 0.77 & 0.61 \\
\hline minerals & 0.3 & 0.49 & 0.32 & 0.4 & 0.37 & 0.35 & 0.33 & 0.4 & 0.65 & -0.36 & -0.46 & -0.48 \\
\hline
\end{tabular}

Table 2: Reliability threshold values for the SEM-EDS data for ceramics, slags, oxidised metal and minerals. Negative values stand for elements that should not be trusted once offered by the INCA software. Copper oxide values are trusted for oxidised metal, while $\mathrm{SnO}_{2}$ and $\mathrm{PbO}$ were not detected in ceramic and slag. 


\begin{tabular}{clcc} 
Name & Description & Selected for & Analytical instrument \\
\hline BIR1 & Basalt glass & slag, ceramic, minerals & SEM-EDS \\
BCR-2 & Basalt glass & slag, ceramic, minerals & SEM-EDS \\
BHVO-2 & Basalt glass & slag, ceramic, minerals & SEM-EDS \\
$\mathrm{Cu}$ No. 096255LN & Pure copper & copper metal phases & EPMA
\end{tabular}

Table 3: CRMs used during SEM-EDS and EPMA analyses of all materials in this study.

Since two different SEM-EDS instruments were used for analysing these samples (Table 1, Philips and JXA-8600), the acquired data are corrected against certified reference materials (CRM), analysed under the same conditions on both machines (Table 3). A correction factor was applied only in cases where divergence was higher than $10 \%$ (Tables 4 and 5).

\subsubsection{EPMA}

EPMA was used for analysing copper metal phases in all studied samples, with particular benefit for detecting present elements present at the ppm $\left(1 / 10^{6}\right)$ level. Seventeen chemical elements were searched for in all samples (Table 1), with analytical background of these adjusted during analysis of certified reference material (CRM) for pure copper. Since the $\mathrm{Zn}$ peak is known to overlap with a $\mathrm{Cu}$ peak, additional analytical work was required for setting the background, hence separate analysis for $\mathrm{Zn}$ and $\mathrm{Cu}$ only (Table 6). Each sample had nine to eleven runs for the best precision data. The analytical conditions were set at accelerating voltage of 20 $\mathrm{kV}$, beam current of $50 \mathrm{nA}$, deadtime $35-40 \%$ and working distance of $10 \mathrm{~mm}$. In order to assess the true presence of trace elements in copper metal phases in various samples, all gained values were assessed in relation to measurements acquired for pure copper CRM (Table 6). During data analysis and interpretation, the threshold for trusted values for trace elements was established at $\geq 10 \mathrm{ppm}$. 


\begin{tabular}{|c|c|c|c|c|c|c|c|c|c|}
\hline Philips & $\begin{array}{l}\mathrm{Na} 2 \mathrm{O} \\
\mathrm{wt} \%\end{array}$ & $\begin{array}{l}\mathrm{MgO} \\
\mathrm{wt} \%\end{array}$ & $\begin{array}{c}\mathrm{Al} 2 \mathrm{O} 3 \\
\mathrm{wt} \%\end{array}$ & $\begin{array}{l}\mathrm{SiO} 2 \\
\mathrm{wt} \%\end{array}$ & $\begin{array}{l}\mathrm{P} 2 \mathrm{O} 5 \\
\mathrm{wt} \%\end{array}$ & $\begin{array}{l}\mathrm{K} 2 \mathrm{O} \\
\mathrm{wt} \%\end{array}$ & $\begin{array}{l}\mathrm{CaO} \\
\text { wt } \%\end{array}$ & $\begin{array}{l}\mathrm{TiO} 2 \\
\text { wt } \%\end{array}$ & $\begin{array}{l}\mathrm{FeO} \\
\mathrm{wt} \%\end{array}$ \\
\hline BIR1 & 2.21 & 10.56 & 15.61 & 51.50 & & 0.00 & 11.20 & 0.84 & 8.09 \\
\hline BIR1 & 1.96 & 10.00 & 15.00 & 49.91 & & 0.00 & 12.48 & 0.92 & 9.73 \\
\hline BIR1 & 2.01 & 10.02 & 15.37 & 50.92 & & 0.00 & 11.93 & 0.88 & 8.87 \\
\hline BIR1 & 1.99 & 10.29 & 15.46 & 51.81 & & 0.00 & 11.45 & 0.94 & 8.07 \\
\hline BIR1 & 1.98 & 10.51 & 15.99 & 51.88 & & 0.00 & 11.08 & 0.86 & 7.71 \\
\hline average BIRI & 2.03 & 10.28 & 15.49 & 51.20 & & 0.00 & 11.63 & 0.89 & 8.49 \\
\hline certified value BIRI & 1.82 & 9.70 & 15.50 & 47.96 & & 0.03 & 13.30 & 0.96 & 11.30 \\
\hline absolute error & 0.21 & 0.58 & -0.01 & 3.24 & & -0.03 & -1.67 & -0.07 & -2.81 \\
\hline relative error & 10.24 & 5.61 & -0.10 & 6.33 & & & -14.37 & -8.34 & -33.05 \\
\hline correction value (above $10 \%$ ) & 0.10 & & & & & & -0.14 & & -0.33 \\
\hline & $\mathrm{Na} 2 \mathrm{O}$ & $\mathrm{MgO}$ & $\mathrm{Al} 2 \mathrm{O} 3$ & $\mathrm{SiO} 2$ & $\mathrm{P} 2 \mathrm{O} 5$ & $\mathrm{~K} 2 \mathrm{O}$ & $\mathrm{CaO}$ & $\mathrm{TiO} 2$ & $\mathrm{FeO}$ \\
\hline Philips & wt $\%$ & $\mathrm{wt} \%$ & $\mathrm{wt} \%$ & wt $\%$ & wt $\%$ & $\mathrm{wt} \%$ & $\mathrm{wt} \%$ & wt $\%$ & wt $\%$ \\
\hline BCR-2 & 3.64 & 4.02 & 13.72 & 58.22 & 0.00 & 1.61 & 6.37 & 1.99 & 10.43 \\
\hline BCR-2 & 3.80 & 3.83 & 13.58 & 58.47 & 0.58 & 1.61 & 6.30 & 2.11 & 9.71 \\
\hline BCR-2 & 3.52 & 3.84 & 13.26 & 57.90 & 0.00 & 1.66 & 6.45 & 2.17 & 11.19 \\
\hline BCR-2 & 3.18 & 3.77 & 13.03 & 57.70 & 0.00 & 1.68 & 6.82 & 2.25 & 11.57 \\
\hline BCR-2 & 3.34 & 3.82 & 13.17 & 58.00 & 0.52 & 1.68 & 6.72 & 2.09 & 10.66 \\
\hline BCR-2 & 3.71 & 3.87 & 13.34 & 58.05 & 0.62 & 1.68 & 6.48 & 2.04 & 10.22 \\
\hline average BCR-2 & 3.53 & 3.86 & 13.35 & 58.06 & 0.29 & 1.65 & 6.52 & 2.11 & 10.63 \\
\hline certified value BCR-2 & 3.16 & 3.59 & 13.50 & 54.10 & 0.35 & 1.79 & 7.12 & 2.26 & 13.80 \\
\hline absolute error & 0.37 & 0.27 & -0.15 & 3.96 & -0.06 & -0.14 & -0.60 & -0.15 & -3.17 \\
\hline relative error & 10.51 & 6.93 & -1.14 & 6.82 & -22.57 & -8.18 & -9.14 & -7.18 & -29.80 \\
\hline correction value (above $10 \%$ ) & 0.11 & & & & -0.23 & -0.08 & -0.09 & & -0.30 \\
\hline & $\mathrm{Na} 2 \mathrm{O}$ & $\mathrm{MgO}$ & $\mathrm{Al} 2 \mathrm{O} 3$ & $\mathrm{SiO} 2$ & $\mathrm{P} 2 \mathrm{O} 5$ & $\mathrm{~K} 2 \mathrm{O}$ & $\mathrm{CaO}$ & $\mathrm{TiO} 2$ & $\mathrm{FeO}$ \\
\hline Philips & wt $\%$ & wt $\%$ & wt $\%$ & wt $\%$ & $\mathrm{wt} \%$ & $\mathrm{wt} \%$ & wt $\%$ & wt $\%$ & $\mathrm{wt} \%$ \\
\hline BHVO-2 & 2.43 & 7.59 & 13.31 & 53.97 & & 0.45 & 10.28 & 2.53 & 9.44 \\
\hline BHVO-2 & 2.63 & 8.08 & 13.76 & 54.41 & & 0.48 & 9.63 & 2.37 & 8.63 \\
\hline BHVO-2 & 2.25 & 7.30 & 13.32 & 52.69 & & 0.47 & 10.62 & 2.87 & 10.48 \\
\hline BHVO-2 & 2.32 & 7.57 & 13.43 & 53.47 & & 0.47 & 10.47 & 2.48 & 9.80 \\
\hline average $\mathrm{BHVO}-2$ & 2.41 & 7.64 & 13.46 & 53.64 & & 0.47 & 10.25 & 2.56 & 9.59 \\
\hline certified value BHVO-2 & 2.22 & 7.23 & 13.50 & 49.90 & & 0.52 & 11.40 & 2.73 & 12.30 \\
\hline absolute error & 0.19 & 0.41 & -0.04 & 3.74 & & -0.05 & -1.15 & -0.17 & -2.71 \\
\hline relative error & 7.72 & 5.33 & -0.33 & 6.96 & & -11.33 & -11.22 & -6.47 & -28.32 \\
\hline correction value (above $10 \%$ ) & 0.08 & & & & & -0.11 & -0.11 & & -0.28 \\
\hline average correction value & 0.09 & & & & -0.23 & -0.10 & -0.12 & & -0.30 \\
\hline correction factor & 0.91 & & & & 1.23 & 1.10 & 1.12 & & 1.30 \\
\hline
\end{tabular}

Table 4: SEM-EDS compositional data of certified reference materials (CRM) for basalt glasses: BIR1, BCR-2, BHVO-2, given in wt\% and conducted on Philips. All measured values are presented against certified average values for CRMs, with correction value calculated only for relative errors above $10 \%$ divergence. The averages of all correction values and correction factor are given in the bottom two lines; the correction factor was applied for calculating real values for samples analysed with this instrument. 


\begin{tabular}{|c|c|c|c|c|c|c|c|c|}
\hline JXA-8600 & $\begin{array}{l}\mathrm{Na} 2 \mathrm{O} \\
\mathrm{wt} \%\end{array}$ & $\begin{array}{l}\mathrm{MgO} \\
\mathrm{wt} \%\end{array}$ & $\begin{array}{c}\mathrm{Al} 2 \mathrm{O} 3 \\
\mathrm{wt} \%\end{array}$ & $\begin{array}{l}\mathrm{SiO} 2 \\
\mathrm{wt} \%\end{array}$ & $\begin{array}{l}\mathrm{K} 2 \mathrm{O} \\
\mathrm{wt} \%\end{array}$ & $\begin{array}{l}\mathrm{CaO} \\
\mathrm{wt} \%\end{array}$ & $\begin{array}{l}\mathrm{TiO} 2 \\
\mathrm{wt} \%\end{array}$ & $\begin{array}{l}\mathrm{FeO} \\
\mathrm{wt} \%\end{array}$ \\
\hline BIR1 & 1.31 & 8.34 & 13.79 & 49.35 & 0.00 & 14.29 & 1.16 & 11.76 \\
\hline BIR1 & 1.41 & 8.45 & 13.93 & 49.49 & 0.00 & 14.42 & 1.24 & 11.05 \\
\hline BIR1 & 1.31 & 8.61 & 13.78 & 49.35 & 0.00 & 14.31 & 1.06 & 11.57 \\
\hline BIR1 & 1.28 & 8.56 & 13.83 & 49.27 & 0.00 & 14.40 & 1.24 & 11.42 \\
\hline average BIR1 & 1.33 & 8.49 & 13.84 & 49.37 & 0.00 & 14.36 & 1.18 & 11.45 \\
\hline certified value BIRI & 1.82 & 9.70 & 15.50 & 47.96 & 0.03 & 13.30 & 0.96 & 11.30 \\
\hline absolute error & -0.49 & -1.21 & -1.66 & 1.41 & -0.03 & 1.06 & 0.22 & 0.15 \\
\hline relative error & -37.04 & -14.26 & -12.03 & 2.85 & & 7.37 & 18.45 & 1.28 \\
\hline correction value (above $10 \%$ ) & -0.37 & -0.14 & -0.12 & & & & 0.18 & \\
\hline & $\mathrm{Na} 2 \mathrm{O}$ & $\mathrm{MgO}$ & $\mathrm{Al} 2 \mathrm{O} 3$ & $\mathrm{SiO} 2$ & $\mathrm{~K} 2 \mathrm{O}$ & $\mathrm{CaO}$ & $\mathrm{TiO} 2$ & $\mathrm{FeO}$ \\
\hline JXA-8600 & $\mathrm{wt} \%$ & wt $\%$ & $\mathrm{wt} \%$ & $\mathrm{wt} \%$ & $\mathrm{wt} \%$ & $\mathrm{wt} \%$ & wt $\%$ & $\mathrm{wt} \%$ \\
\hline BCR-2 & 2.13 & 3.10 & 12.30 & 56.01 & 1.97 & 7.73 & 2.54 & 14.22 \\
\hline BCR-2 & 2.16 & 3.06 & 12.48 & 56.27 & 1.95 & 7.66 & 2.51 & 13.92 \\
\hline BCR-2 & 2.37 & 3.12 & 12.27 & 55.62 & 2.02 & 7.86 & 2.63 & 14.10 \\
\hline BCR-2 & 2.19 & 3.07 & 12.28 & 56.19 & 1.98 & 7.61 & 2.51 & 14.17 \\
\hline BCR-2 & 2.22 & 3.14 & 12.16 & 56.54 & 1.93 & 7.74 & 2.53 & 13.72 \\
\hline average $B C R-2$ & 2.22 & 3.10 & 12.30 & 56.13 & 1.97 & 7.72 & 2.54 & 14.03 \\
\hline certified value BCR-2 & 3.16 & 3.59 & 13.50 & 54.10 & 1.79 & 7.12 & 2.26 & 13.80 \\
\hline absolute error & -0.94 & -0.49 & -1.20 & 2.03 & 0.18 & 0.60 & 0.28 & 0.23 \\
\hline relative error & -42.59 & -15.81 & -9.77 & 3.61 & 9.15 & 7.77 & 11.19 & 1.61 \\
\hline correction value (above $10 \%$ ) & -0.43 & -0.16 & -0.10 & & 0.09 & & 0.11 & \\
\hline & $\mathrm{Na} 2 \mathrm{O}$ & $\mathrm{MgO}$ & $\mathrm{Al} 2 \mathrm{O} 3$ & $\mathrm{SiO} 2$ & $\mathrm{~K} 2 \mathrm{O}$ & $\mathrm{CaO}$ & $\mathrm{TiO} 2$ & $\mathrm{FeO}$ \\
\hline JXA-8600 & wt $\%$ & wt $\%$ & wt $\%$ & wt $\%$ & $\mathrm{wt} \%$ & $\mathrm{wt} \%$ & $\mathrm{wt} \%$ & wt $\%$ \\
\hline BHVO-2 & 1.76 & 6.15 & 12.29 & 51.73 & 0.56 & 12.25 & 3.18 & 12.08 \\
\hline BHVO-2 & 1.52 & 6.28 & 12.43 & 51.64 & 0.77 & 11.98 & 3.12 & 12.25 \\
\hline BHVO-2 & 1.70 & 6.50 & 12.10 & 51.72 & 0.48 & 11.97 & 3.05 & 12.49 \\
\hline BHVO-2 & 1.62 & 6.41 & 12.20 & 51.51 & 0.52 & 11.93 & 3.20 & 12.60 \\
\hline BHVO-2 & 1.45 & 6.36 & 12.19 & 51.89 & 0.58 & 12.07 & 2.95 & 12.52 \\
\hline average $B H V O-2$ & 1.61 & 6.34 & 12.24 & 51.70 & 0.58 & 12.04 & 3.10 & 12.39 \\
\hline certified value BHVO-2 & 2.22 & 7.23 & 13.50 & 49.90 & 0.52 & 11.40 & 2.73 & 12.30 \\
\hline absolute error & -0.61 & -0.89 & -1.26 & 1.80 & 0.06 & 0.64 & 0.37 & 0.09 \\
\hline relative error & -37.85 & -14.05 & -10.28 & 3.48 & 10.64 & 5.32 & 11.96 & 0.72 \\
\hline correction value (above $10 \%$ ) & -0.38 & -0.14 & -0.10 & & 0.11 & & 0.12 & \\
\hline average correction values & -0.39 & -0.15 & -0.11 & & 0.10 & & 0.14 & \\
\hline correction factor & 1.39 & 1.15 & 1.11 & & 0.90 & & 0.86 & \\
\hline
\end{tabular}

Table 5: SEM-EDS compositional data of certified reference materials (CRM) for basalt glasses: BIR1, BCR-2, BHVO-2, given in wt\% and conducted on JXA-8600. All measured values are presented against certified average values for CRMs, with correction value calculated only for relative errors above $10 \%$ divergence. The averages of all correction values and correction factor are given in the bottom two lines; the correction factor was applied for calculating real values for samples analysed with this instrument. 


\subsection{Reporting and Data Processing}

Photomicrographs were carefully labelled for sample magnification and polarisation under which they were taken. The SEM data were searched for particular elements within the INCA software, during which process analytical reliability threshold was established for each of them (Table 22). These data were then extracted from the (INCA) analytical software into Excel spreadsheets and subsequently digested in more detail. Statistical analyses were conducted in Excel, and SPSS (ver. 17) and 'R' statistical analysis software environments, while ternary diagrams were produced using OriginPro8. Where necessary, images were processed in Photoshop CS2.

Compositional data are presented here as percent by weight (wt $\%$ ) unless stated otherwise, typically determining oxygen by stoichiometry rather than by elemental analysis. We used atomic weight in cases when it was necessary to identify a formula of a particular newly-formed phase in the slag matrix, or a mineral phase in a copper ore.

All data presented in the main texts were corrected against CRMs (Tables 3). While accuracy of the SEM-EDS data was tested against CRM for basalt glass (BHVO-2, BIR1, BCR-2, Tables 4 and 5), the EPMA measurements were corrected against CRM for registered standard No. 096255LN for pure copper (from the Reference standards for X-Ray Microanalysis, Micro-Analysis Consultants, Ltd) (Table 6). The corrected EPMA data is reported to ppm level, while acknowledging an error margin of an estimated 5-10\% relative for absolute values below $1 \mathrm{wt} \%$. 


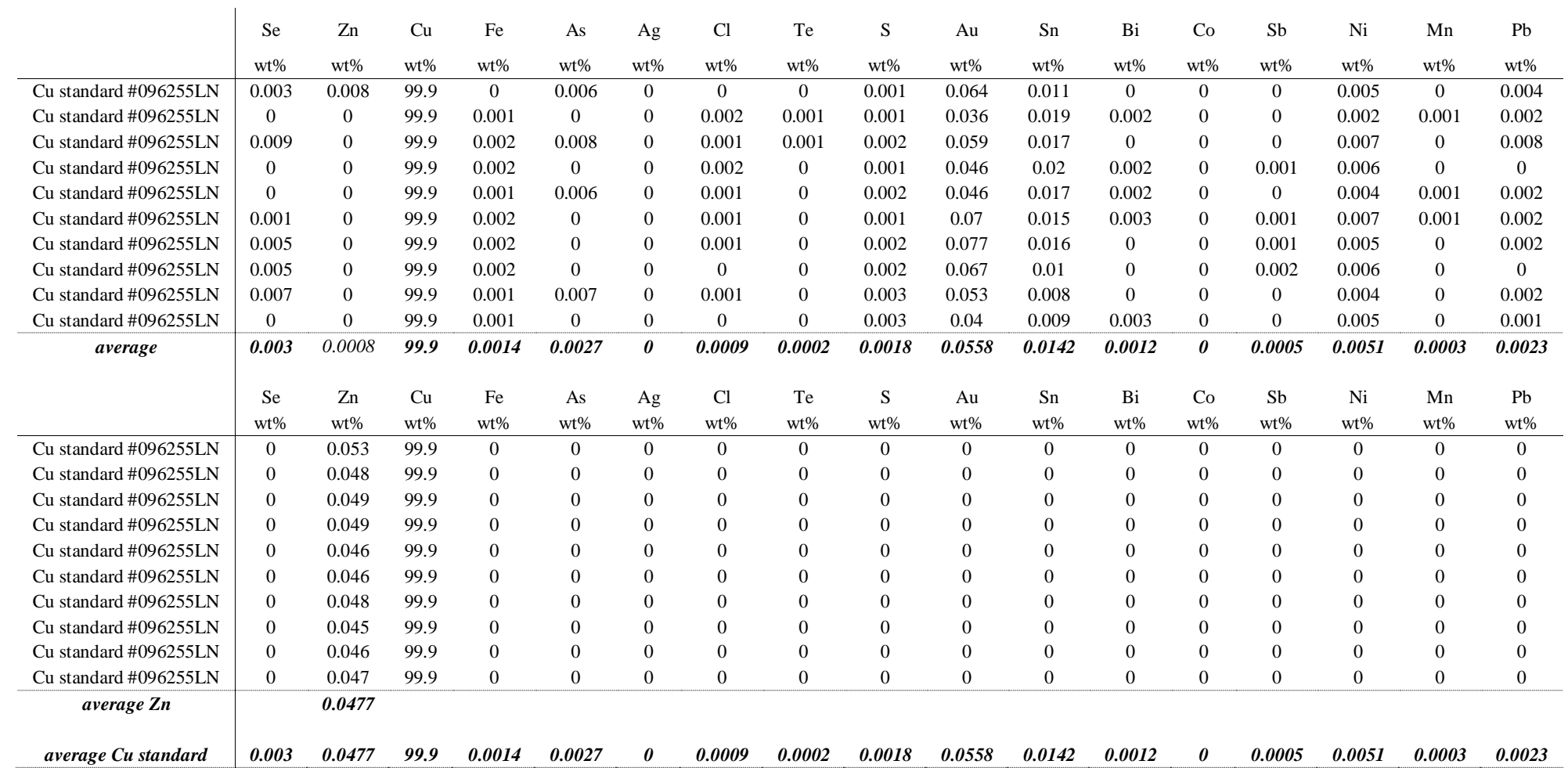

Table 6: EPMA compositional analyses for copper standard \#096255LN, expressed in wt\%. Average values for trace elements (bottom line) were used to subtract from the trace element values measured for all copper metal artefacts and metal phases in the studied samples, with an aim to present the true presence of trace elements in them. 


\section{A brief geological overview}

\subsection{Copper in the Balkans}

Copper ores represent one of the main mineral deposits exploited to the present day in Serbia. The largest copper producing mines are located in Bor, a mining district in eastern Serbia, although there are a few more in central, west and south Serbia (Fig. 1). The dominant types are porphyry copper and massive sulfide deposits with significant $\mathrm{Pb}, \mathrm{Zn}$, and $\mathrm{Au}$ mineralisation (Janković 1967; Jelenković 1999; Neubauer and Heinrich 2003; Monthel et al. 2002). The porphyry deposits at Bor also carry enargite (copper-arsenic-sulfide), a common mineral for this locality (Sillitoe 1983). Gold deposits are particularly interesting since they were discovered in many localities in the Bor area (Fig. 2), largely followed by copper, but also by Sn-W-Mo mineralisation, as in Blagojev kamen (Fig. 3). However, the richest occurrence of tin (cassiterite) is related to the west Serbian deposits in Bukulja and Cer (Jelenković 1999: 145-146).

The Bor district forms part of a larger metallogenic subprovince (Bor-Srednegorie) within the Carpatho-Balkan metallogenic unit, which is characterised by an abundance of base and precious metals (Au, Ag) (Janković 1997: 431; Neubauer and Heinrich 2003). The BorSrednegorie subprovince stretches from Transylvania via Bor to Srednegorie in central Bulgaria and ends near the Black Sea coast in the Burgas region in Bulgaria. It is characterised by morphologically variable copper occurrences: in Bor and Panagyurishte there are porphyry (Majdanpek, Assarel, Elacite) and massive sulfide deposits (Radka), while in the Burgas ore district the mineralisation of vein quartz-chalcopyrite association (Zidarovo, Rossen) prevails (Bogdanov 1982). Copper deposits in this subprovince are commonly accompanied by gold, silver, lead-zinc and molybdenum.

Another important metallogenic unit, the Serbo-Macedonian unit, stretches in parallel to the Carpatho-Balkan unit, cutting across central Serbia and Macedonia and ending at the Chalkidiki shores in Greece. It is abundant with lead, zinc, copper and antimony, but also accompanied by gold, silver, arsenic, thallium, bismuth and iron (Janković 1997: 431; Jelenković 1999: 14). This unit is noteworthy as it includes the areas with ancient mining of copper (Rudnik), silver (Avala, Kosmaj, Srebrenica) and modern exploitation of lead and zinc (Trepča) (Jovanović 1983; Dušanić 1995; Hirt 2010). 


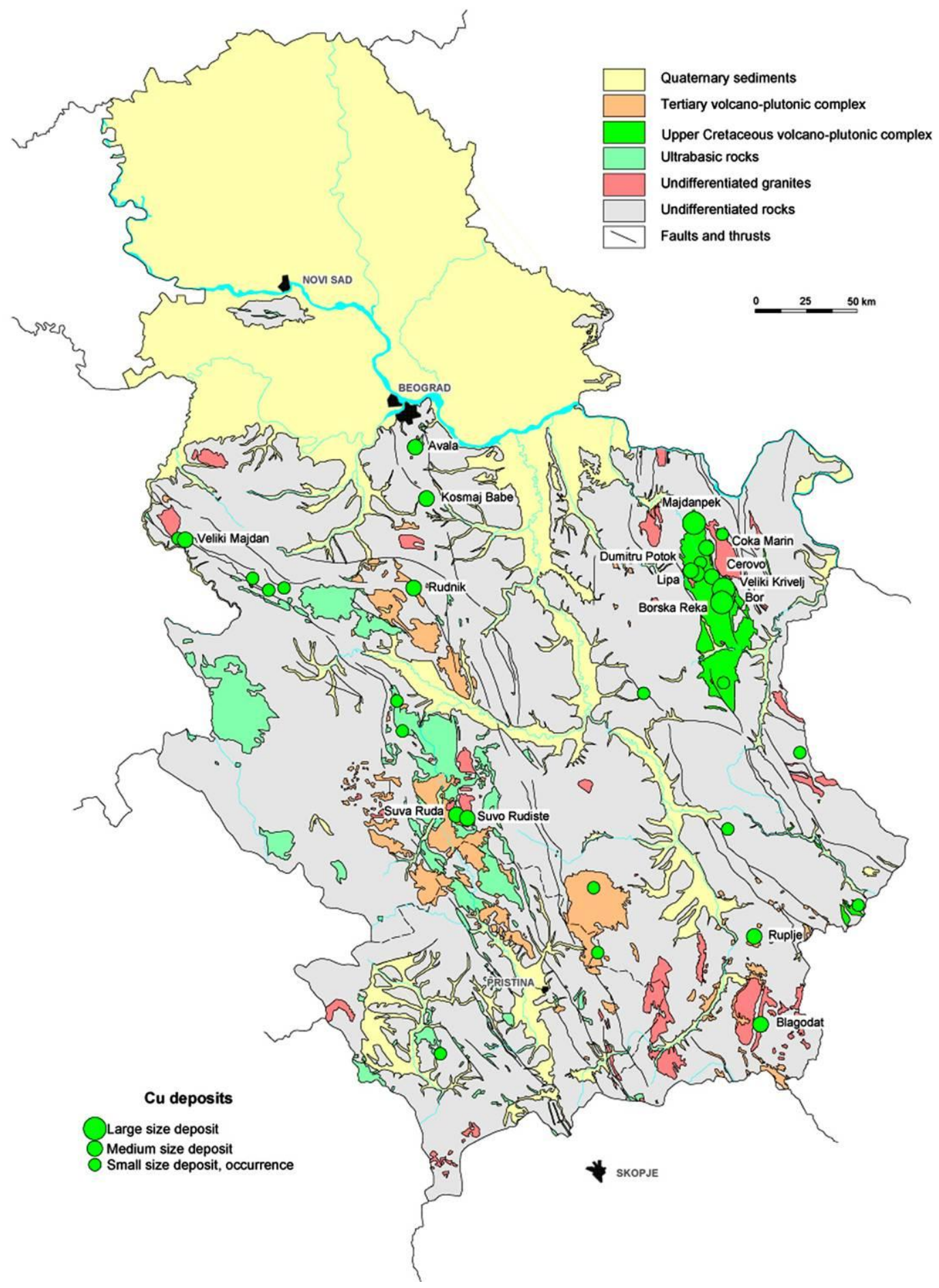

Figure 1- Copper deposits in Serbia (after Monthel et al., 2002, p. 35, Fig. 14). 


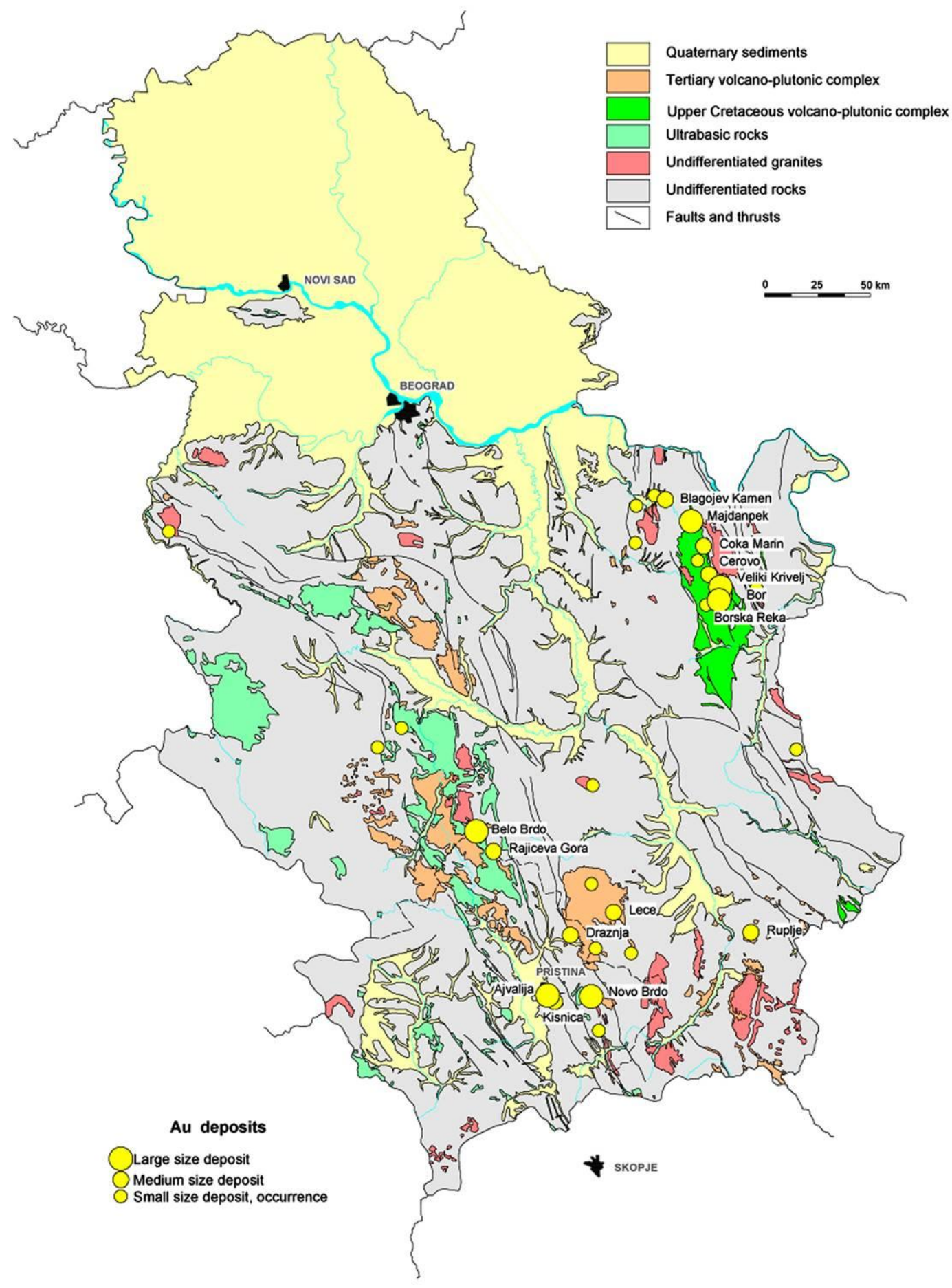

Figure 2- Gold deposits in Serbia (after Monthel et al., 2002, p. 40, Fig. 19). 


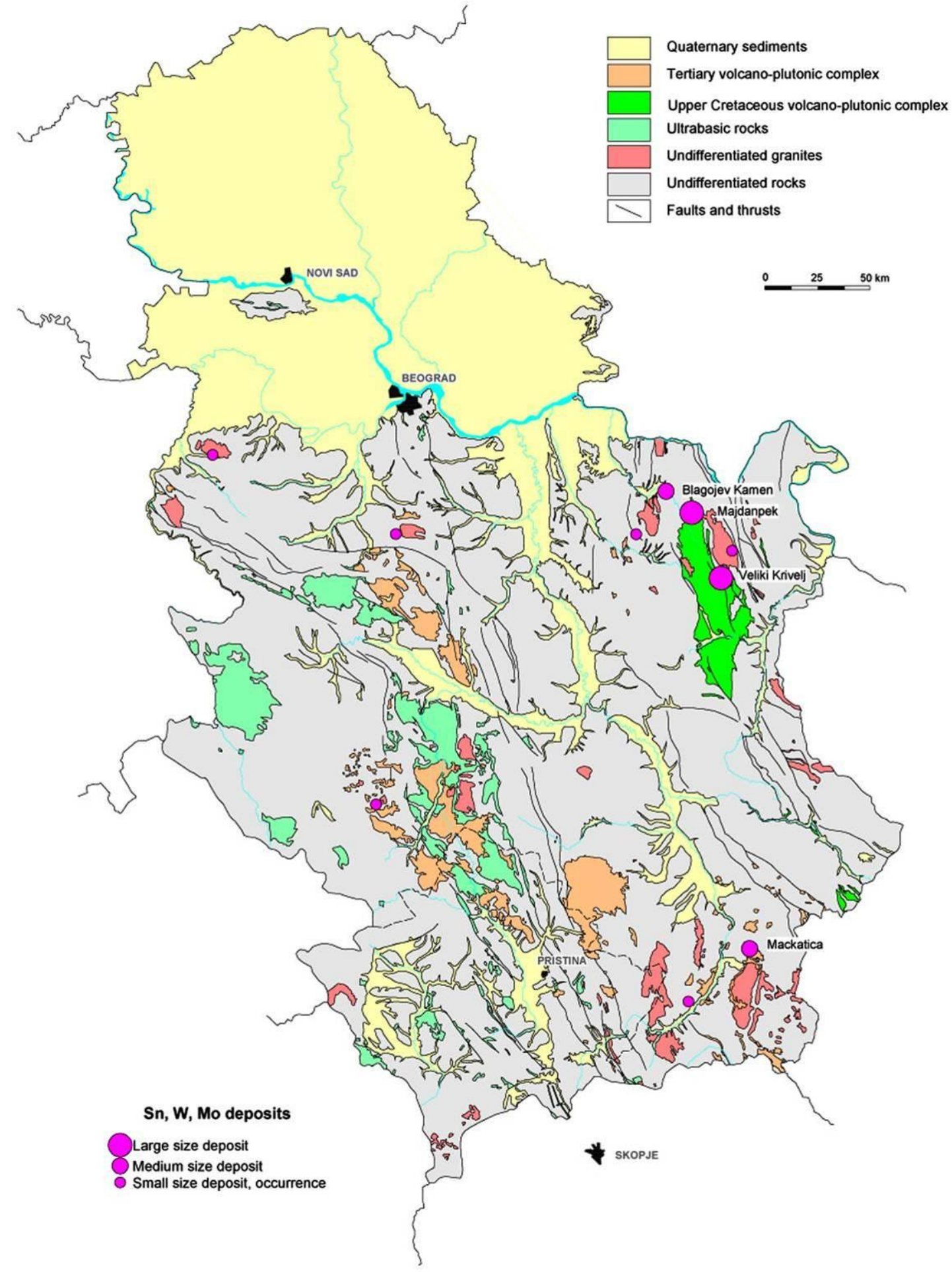

Figure 3- Tin-tungsten-molybdenum deposits in Serbia (after Monthel et al., 2002, p. 39, Fig. 18). 
The dominance of lead and zinc occurrence together with massive sulfide and porphyry copper deposits is not only characteristic of the Balkan metallogeny, but also of the massive Tethyan Eurasian metallogenic belt (TEMB) that formed on the southern margin of Eurasia (Janković 1977, 1997). This c. 10,000 km long belt with similar metallogenic features runs from the western Mediterranean via the Alps and southeast Europe, the Pontides and Anatolia, Iran and Afghanistan, passing into the Tibet Plateau, and reaching Burma and Sumatra only to link with the West Pacific metallogenic belt. The TEMB includes confirmed traces of ancient copper mining from the early beginnings in western Eurasia, and importantly so, of complex copper ores including tin-bearing ones (e.g. Deh Hosein in Iran, Mushiston in Tajikistan) (Weisgerber and Cierny 2002; Nezafati et al. 2011; Stöllner et al. 2011). The discussion on the early appearance of copper metallurgy in western Eurasia therefore involves early histories of the use of other metals, particularly in the light of the geological opulence of various metal deposits in this area.

\subsection{Phosphates, arsenates and vanadates in the context of Balkan metallogeny}

We dedicate further attention to the formation of several specific minerals mentioned in this paper: apatite, vivianite, scorodite, strengite and arthurite, all of which belong to the same class of minerals, termed phospates, arsenates and vanadates.

Apatite $\left(\mathrm{Ca}_{5}\left(\mathrm{PO}_{4}\right)_{3}(\mathrm{OH}, \mathrm{F}, \mathrm{Cl})\right.$ is the most common phosphate mineral, which includes Fluorapatite, Chlorapatite and Hydroxyl-apatite, of which fluorapatite is the most ordinary form of apatite in nature. Apatite occurs in rocks of various kinds and ages, but most commonly in metamorphic crystalline rocks and in many metalliferous veins (tin mostly), also in gneiss, syenite, hornblendic gneiss, mica schist, beds of iron ore. Colour varies from white, sea-green to black (Dana and Ford 1922, p. 595-597).

Vivianite $\left[\mathrm{Fe}_{3}\left(\mathrm{PO}_{4}\right)_{2} \bullet 8 \mathrm{H}_{2} \mathrm{O}\right]$ is a mineral that belongs to the eponymous group of phosphates. It can be colourless and pale green, and with oxidation it becomes dark blue, dark greenish blue, indigo-blue, and then black. Interestingly for the context of early metallurgy, it colours the flame to bluish green when set on fire. It occurs in association with pyrrhotite and pyrite 
in copper and tin veins, less frequently in narrow veins with gold, or limonite, or bog iron ore (Dana and Ford 1922, p. 608; Anthony et al. 2000, p. 632).

Both scorodite $\left(\mathrm{FeAsO}_{4} \cdot 2 \mathrm{H}_{2} \mathrm{O}\right)$ and strengite $\left(\mathrm{FePO}_{4} \cdot 2 \mathrm{H}_{2} \mathrm{O}\right)$ belong to the variscite mineral group; while scorodite commonly occurs as secondary mineral resulting from the oxidation of arsenopyrite other arsenic-bearing species, strengite is formed by the alteration of ironbearing phosphates, but also can be found in limonite ore deposits and gossans. The colour of scorodite is green-blue, while strengite varies from colourless to violet. Interestingly, scorodite colours the flame in blue (Dana and Ford 1922, p. 610). Both scorodite and strengite occur in association with vivianite and iron ores, while apatite is more commonly found with strengite (Anthony et al. 2000, p. 531, 567)

Arthurite $\left(\mathrm{CuFe}_{2}\left(\mathrm{AsO}_{4}, \mathrm{PO}_{4}, \mathrm{SO}_{4}\right)_{2} \cdot 4 \mathrm{H}_{2} \mathrm{O}\right)$ occurs in association with scorodite (among others) and forms in oxidised zone of some copper deposits, or by alteration of arsenopyrite or enargite. It is mainly coloured as apple-green (Anthony et al. 2000).

According to mineralogical data, there is a great likelihood that these minerals would paragene in the same, or similar, locality, which in our case could be characterised as the deposit of primary copper ore, with occurrences of iron ores, arsenopyrites and arsenicbearing species (like enargite).

Significant massive sulfide deposits of cupriferous pyrite are found in the Bor district in eastern Serbia, together with volcanogenic massive polymetallic deposits that contain a pyritic $\mathrm{Zn}-\mathrm{Cu}-\mathrm{Pb}$ association (Janković 1990). These are situated in the zone $80 \mathrm{x} 20 \mathrm{~km}$ as a part of the Carpathian-Balkan metallogenic province, which belongs to the Tethyan Eurasian metallogenic belt (Janković 1977). This massive suphide ore body is particularly interesting as it contains high concentrations of pyrite and copper minerals (chalcopyrite and bornite) with significant contents of chalcocite, covellite and enargite (Janković 1990, p. 471). The economic importance of enargite in addition to copper in the Bor district has also been documented by Sillitoe (1983).

The trace element enrichment of $\mathrm{Ag}, \mathrm{Sb}, \mathrm{As}, \mathrm{Ti}, \mathrm{Se}$, and to some extent of $\mathrm{Pb}, \mathrm{Zn}$ and $\mathrm{Sn}$ has been established in the massive deposition of chalcopyrite-bornite-pyrite in the Bor district (Janković 1990, p. 473). Also, the polymetallic deposition in the Čoka Marin region (within the Bor district) revealed significant content of gold, occurring as native gold and/or 
associated with sulfides. Chalcopyrite, enargite, cassiterite and stannite are only some of the minerals associated with this particular locality (Janković 1990, p. 475).

Thus, given the geological characterisation of the nearest mining region to the three sites with early metal production evidence, there is a great likelihood that all colourful minerals mentioned in our research could have been associated in the same locality in eastern Serbia. We are not arguing here for the exploitation of a particular deposit but rather that the possibility is high in the Bor district in eastern Serbia to come across all minerals like apatite, vivianite, scorodite, strengite or arthurite while prospecting for copper ores. Belovode is the site closest to these deposits, and we do not exclude the possibility of the existence of an ore exchange network at the time maintained by the Belovode miners, for instance.

Anthony, J. W., Bideaux, R. A., Bladh, K. W., \& Nichols, M. C. (Eds.). (2000). Handbook of Mineralogy, Volume IV. Arsenates, Phosphates, Vanadates. Tucson, Arizona: Mineral Data Publishing.

Bogdanov, B. (1982). Bulgaria. In F. W. Dunning, W. Mykura, \& D. Slater (Eds.), Mineral Deposits of Europe. Volume 2: Southeast Europe (pp. 215-232). London: The Institution of Mining and Metallurgy and the Mineralogical Society.

Dana, E. S., \& Ford, W. E. (1922). A Textbook of Mineralogy (with an extended treatise on crystallography and physical mineralogy) (3rd edition ed.). New York: John Wiley and Sons.

Dušanić, S. (1995). Late Roman mining in Illyricum: historical observations. In P. Petrović, \& S. Đurđekanović (Eds.), Ancient Mining and Metallurgy in southeast Europe (pp. 219-226). Bor, Belgrade: Archaeological Institute Belgrade and Museum of Mining and Metallurgy Bor.

Hirt, A. M. (2010). Imperial Mines and Quarries in the Roman World: Organisational Aspects, 27 BC - AD 235. Oxford: Oxford University Press.

Janković, S. (1967). Ležišta Metaličnih Mineralnih Sirovina. Belgrade: Mining and Geology Faculty, University of Belgrade.

Janković, S. (1977). The copper deposits and geotectonic setting of the Thethyan Eurasian Metallogenic Belt. Mineralium Deposita, 12(1), 37-47, doi:10.1007/bf00204503.

Janković, S. (1990). Types of copper deposits related tovolcanic environment in the Bor district, Yugoslavia. Geologische Rundschau, 79(2), 467-478.

Janković, S. (1997). The Carpatho-Balkanides and adjacent area: a sector of the Tethyan Eurasian metallogenic belt. Mineralium Deposita, 32(5), 426-433, doi: $10.1007 / \mathrm{s} 001260050110$.

Jelenković, R. (1999). Ležišta metaličnih mineralnih sirovina (Metallic Mineral Deposits, in Serbian). Belgrade: Mining and Geology Faculty, University of Belgrade.

Jovanović, B. (1983). Mali Šturac, ein neues prähistorisches Kupferbergwerk in Zentralserbien. Der Anschnitt, 4-5, 177-179. 
Monthel, J., Vadala, P., Leistel, J. M., \& Cottard, F. (2002). Mineral Deposits and Mining Districts of Serbia. Belgrade: Republic of Serbia Ministry of Mining and Energy, Geoinstitut Belgrade and Mining and Geology Faculty Belgrade.

Neubauer, F., \& Heinrich, C. Late Cretaceous and Tertiary geodynamics and ore deposit evolution of the Alpine-Balkan-Dinaride orogen. In D. Eliopoulos (Ed.), Mineral Exploration and Sustainable Development. Proceedings of the Seventh Biennial SGA Meeting on Mineral Exploration and Sustainable Development, Athens, Greece, August 24-28, 2003, Athens, 2003 (pp. 1133-1136): Millpress

Nezafati, N., Pernicka, E., \& Momenzadeh, M. (2011). Early tin-copper ore from Iran, a possible clue for the enigma of Bronze Age tin. In Ü. Yalçın (Ed.), Anatolian Metal V, Der Anschnitt, Beiheft 24 (Vol. 24, pp. 211-230). Bochum: Deutsches BergbauMuseum.

Sillitoe, R. H. (1983). Enargite-bearing massive sulfide deposits high in porphyry copper systems. Economic Geology, 78, 348-352.

Stöllner, T., Samaschev, Z., Berdenov, S., Cierny, J., Doll, M., Garner, J., et al. (2011). Tin from Kazakhstan - Steppe Tin for the West? In Ü. Yalçın (Ed.), Anatolian Metal V, Der Anschnitt, Beiheft 24 (pp. 231-251). Bochum: Deutsches Bergbau-Museum.

Weisgerber, G., \& Cierny, J. (2002). Tin for ancient Anatolia? In Ü. Yalçın (Ed.), Anatolian Metal II, Der Anschnitt, Beiheft 15 (Vol. 15, pp. 179-187, Vol. Der Anschnitt). Bochum: Deutsches Bergbau-Museum. 